\title{
Algoritmos evolutivos para predição de estruturas de proteínas
}

\author{
Telma Woerle de Lima
}




\section{Algoritmos evolutivos para predição de estruturas de proteínas}

\section{Telma Woerle de Lima}

Orientador:

Prof. Dr. Alexandre Cláudio Botazzo Delbem

Dissertação apresentada ao Instituto de Ciências Matemáticas e de Computação ICMC-USP, como parte dos requisitos para a obtenção do título de Mestre em Ciências de Computação e Matemática Computacional.

\section{USP - São Carlos}

Setembro/2006

\section{"VERSÃO REVISADA APÓS A DEFESA"}

Visto do Orientador: 
Dedico este trabalho a minha família. 


\section{Agradecimentos}

A toda a minha família pelo carinho e apoio recebidos, em especial a minha mãe, meu pai, meu irmão e minha tia Nilce pelo apoio financeiro e emocional sem o qual o desenvolvimento deste trabalho não teria sido possível.

Ao meu orientador Prof. Dr. Alexandre Cláudio Botazzo Delbem, pelo apoio e orientação neste projeto e por tudo que aprendi com ele para desenvolver uma boa pesquisa.

Ao Prof. Dr. Fernando Federson pela amizade, apoio, conselhos e seu tempo depreendido em me auxiliar em algumas dificuldades encontradas durante o desenvolvimento deste trabalho.

Aos amigos, pela amizade oferecida, em especial as minhas amigas de república, durante dois anos e meio, Andréa, Carol e Carla pelos momentos compartilhados juntas e por terem me auxiliado sempre no que podiam. Ao amigo do mestrado em Engenharia Elétrica - USP, Rodrigo, pelo auxílio no desenvolvimento deste trabalho e pela sua amizade.

Ao amigo Paulo pela amizade e pelo auxílio no desenvolvimento de algumas etapas deste trabalho.

Ao Anderson pelo apoio emocial, pela paciência comigo nos momentos tensos de término deste trabalho e pelo auxílio na escrita e desenvolvimento de algumas imagens utilizadas neste trabalho.

Aos Profs. Dr. Carlos Fischer e Ivan Rizzo pela sua orientação e sugestões durante meus projetos de iniciação científica e de conclusão de curso que deram origem ao desenvolvimento deste trabalho.

Ao CNPQ, pelo fundamental suporte financeiro dispensado à execução desta pesquisa. 


\section{Resumo}

A Determinação da Estrutura tridimensional de Proteínas (DEP) a partir da sua seqüência de aminoácidos é importante para a engenharia de proteínas e o desenvolvimento de novos fármacos. Uma alternativa para este problema tem sido a aplicação de técnicas de computação evolutiva. As abordagens utilizando Algoritmos Evolutivos (AEs) tem obtido resultados relevantes, porém estão restritas a pequenas proteínas, com dezenas de aminoácidos e a algumas classes de proteínas. Este trabalho propõe a investigação de uma abordagem utilizando AEs para a predição da estrutura terciária de proteínas independentemente do seu tamanho e classe. Os resultados obtidos demonstram que apesar das dificuldades encontradas a abordagem investigada constitue-se em uma alternativa em relação aos métodos clássicos de determinação da estrutura terciária das proteínas. 


\section{Abstract}

Protein structure determination (DEP) from aminoacid sequences is very importante to protein engineering and development of new drugs. Evolutionary computation has been aplied to this problem with relevant results. Nevertheless, Evolutionary Algorithms (EAs) can work with only proteins with few aminoacids and some protein classes. This work proposes an approach using AEs to predict protein tertiary structure independly from their size and class. The obtained results show that, despite of the difficulties that have been found, the investigate approach is a relevant alternative to classical methods to protein structure determination. 


\section{Lista de Figuras}

2.1 Esquema do Modelo NSGA-II (Deb, 2001) . . . . . . . . . . . . . . . . 21

2.2 Cálculo da distância de multidão no NSGA-II (Deb, 2001) . . . . . . . . . . 21

3.1 Estrutura geral de um aminoácido. . . . . . . . . . . . . . . 27

3.2 Classificação dos vinte aminoácidos padrões encontrados em proteínas. . 29

3.3 Processo de formação de uma ligação peptídica. . . . . . . . . . . . . . . . 31

3.4 Representação dos átomos no mesmo plano. . . . . . . . . . . . . . . . . 32

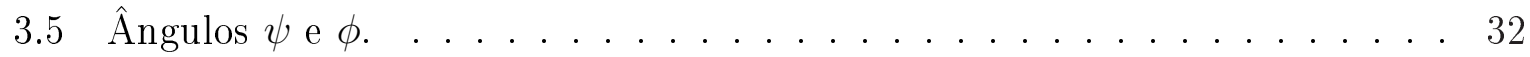

3.6 Mapa de Ramachandran. . . . . . . . . . . . . . . . . . . . 33

3.7 Esquema de uma Volta $\beta . \ldots \ldots \ldots \ldots . \ldots \ldots$

$3.8 \alpha$ hélice. . . . . . . . . . . . . . . . . . . 35

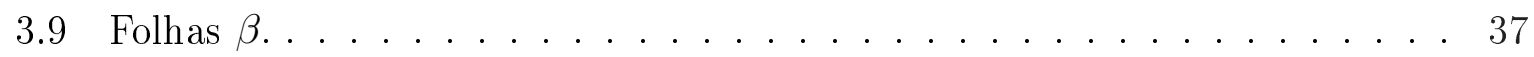

3.10 Estrutura terciária da proteína Crambin (PDB 1CRN). . . . . . . . . 38

3.11 Repressor Lac tetrâmero ligado ao DNA (Petsko and Ringe, 2004). ... . 39

3.12 Estrutura da Alanina Racemase. . . . . . . . . . . . . . . . . . . . . . 40

3.13 Motivos Estruturais de Proteínas do Domínio $\alpha . \ldots . . . . .41$

3.14 Motivos Estruturais de Proteínas do Domínio $\alpha / \beta$. . . . . . . . . . . . 42

3.15 Motivos Estruturais de Proteínas do Domínio $\beta$. . . . . . . . . . . . . 45

5.1 Gráfico da função de energia potencial de comprimento de ligação. . . . . . 77

5.2 Gráfico da função de energia potencial de torção. . . . . . . . . . . . . . . 80

5.3 Gráfico da função de van der Waals na forma padrão. . . . . . . . . . . . . . 83

5.4 Gráfico da função de van der Waals aplicada nos AEs. . . . . . . . . . . . . 84

5.5 Gráfico da função de energia eletrostática. . . . . . . . . . . . . . . . 85

6.1 Estruturas dos polipeptídeos da proteína 1ENH. . . . . . . . . . . . . . . 91

6.2 Convergência do AE para o melhor indivíduo dos polipeptídeos da 1ENH. . 93

6.3 Estruturas terciárias da proteína 1CTF. . . . . . . . . . . . . . 94

6.4 Convergência do AE para o melhor indivíduo da proteína 1CTF. . . . . . . 95

6.5 Estruturas terciárias da proteína 1ENH. . . . . . . . . . . . . . . 96

6.6 Convergência do AE para o melhor indivíduo da proteína 1ENH. . . . . . . 97 
6.7 Estruturas dos polipeptídeos da proteína 1HOE. . . . . . . . . . . . . . . . 99

6.8 Fronteira de Pareto do primeiro polipeptídeo da proteína 1HOE. . . . . . . 100

6.9 Distribuição dos indivíduos na fronteira de Pareto dividos em 2 objetivos para o primeiro polipeptídeo da proteína 1HOE. . . . . . . . . . . . . . . . 101

6.10 Estruturas terciárias da proteína 1HOE. . . . . . . . . . . . . . . . 102

6.11 Fronteira de Pareto da proteína 1HOE. . . . . . . . . . . . . . . . 103

6.12 Distribuição dos indivíduos na fronteira de Pareto dividos em 2 objetivos para a proteína 1HOE. . . . . . . . . . . . . . . . . 103

6.13 Estruturas terciárias da proteína 1ENH. . . . . . . . . . . . . . 105

6.14 Convergência do AE para o melhor indivíduo da proteína 1ENH. . . . . . . 105 


\section{Lista de Tabelas}

2.1 Diferentes Modelos de AEMO . . . . . . . . . . . . . . . . . 20

3.1 Relação dos vinte aminoácidos padrões e respectivos mnemônicos. . . . . . 28

4.1 Exemplo de codificação do modelo lattice. (Braden, 2002) . . . . . . . . . 57

6.1 DME das estruturas dos polipeptídeos das proteínas selecionadas. . . . . . 90

6.2 Função de avaliação do melhor indivíduo representando as estruturas dos polipeptídeos das proteínas selecionadas. . . . . . . . . . . . . . . 92

6.3 DME das estruturas das proteínas selecionadas. . . . . . . . . . . . . . . . 93

6.4 Fitness do melhor indivíduo representando as estruturas das proteínas selecionadas. . . . . . . . . . . . . . . . . . . . 94

6.5 DME das estruturas das proteínas selecionadas obtidos com o AE combinatório. . . . . . . . . . . . . . . . . 96

6.6 Fitness do melhor indivíduo representando as estruturas das proteínas selecionadas para o AE combinatório. . . . . . . . . . . . . . . 96

6.7 DME das estruturas dos polipeptídeos das proteínas selecionadas obtidas pelo AE multi-objetivo. . . . . . . . . . . . . . . . . . . . . . . . 98

6.8 DME das estruturas das proteínas selecionadas. . . . . . . . . . . . . . 101

6.9 DME das estruturas das proteínas selecionadas obtidos com o AE combinatório. . . . . . . . . . . . . . . . . . . . . . 104

6.10 Função de avaliação do melhor indivíduo representando as estruturas das proteínas selecionadas para o AE combinatório. . . . . . . . . . . . 106 


\title{
Lista de Abreviaturas e Siglas
}

\author{
AE Algoritmo Evolutivo \\ AG Algoritmo Genético \\ DEP Determinação da Estrutura da Proteína
}

IA Inteligência Artificial

PDB Protein Data Bank

PSP Predição de Estrutura de Proteína 


\section{Sumário}

1 Introdução 1

2 Computação Evolutiva 5

2.1 Motivação . . . . . . . . . . . . . . . . . . . . . 6

2.2 Base Biológica . . . . . . . . . . . . . . . . . 7

2.2.1 Teoria da Evolução . . . . . . . . . . . . . . . . . . . . 7

2.3 Algoritmos Genéticos . . . . . . . . . . . . . . . . . . . 8

2.3.1 Codificação dos Indivíduos . . . . . . . . . . . . . . . . . . . 10

2.3.2 Definição da População Inicial . . . . . . . . . . . . . . . . . . . . . . . . . . 11

2.3.3 Operadores Genéticos . . . . . . . . . . . . . . . . . . . . . 11

2.3.4 Seleção dos Indivíduos para a Próxima Geração . . . . . . . . . . . . 14

2.4 Outras Técnicas Evolutivas . . . . . . . . . . . . . . . 15

2.4.1 Estratégias Evolutivas . . . . . . . . . . . . . . . 16

2.4.2 Programação Evolutiva . . . . . . . . . . . . . . . . . . 17

2.4.3 Sistemas Classificadores . . . . . . . . . . . . . . . . 17

2.4 .4 Programação Genética . . . . . . . . . . . . . . . . . 18

2.5 Algoritmos Evolutivos Multi-Objetivo . . . . . . . . . . . . . . 18

2.5.1 NSGA-II . . . . . . . . . . . . . . . . . . . . . . . 19

2.5.2 Distância de Multidão . . . . . . . . . . . . . . . 21

2.6 Considerações Finais . . . . . . . . . . . . . . . . . . . . 22

3 Introdução à Estrutura de Proteínas $\quad 25$

3.1 Aminoácidos . . . . . . . . . . . . . . . . . . . 26

3.2 Ligações Peptídicas e os Polipeptídeos . . . . . . . . . . . . . . . . . . 30

3.2.1 Propriedades das Ligações Peptídicas . . . . . . . . . . . . . . . 31

3.3 A Conformação das Proteínas . . . . . . . . . . . . . . . . . . . . 33

3.4 Estrutura Secundária . . . . . . . . . . . . . . . . . . . . 33

3.4 .1 Volta $\beta \ldots \ldots \ldots \ldots \ldots$

$3.4 .2 \quad \alpha$-Hélice . . . . . . . . . . . . . . . . . 35

3.4 .3 Folhas $\beta \ldots \ldots \ldots \ldots \ldots$ 
3.5 Estrutura Terciária . . . . . . . . . . . . . . . . . 37

3.5.1 Domínio de Proteínas . . . . . . . . . . . . . . . . . . . . . 39

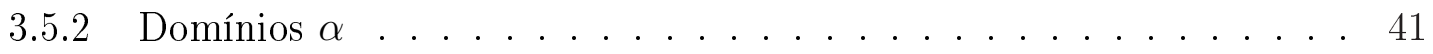

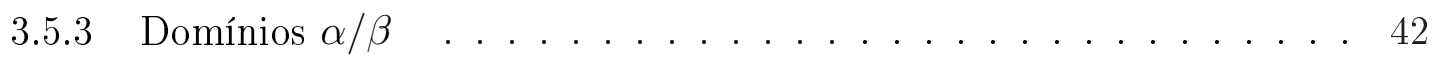

3.5.4 Domínios $\beta \ldots \ldots . \ldots \ldots . \ldots . \ldots . \ldots . \ldots 43$

3.6 Determinação da Estrutura Terciária . . . . . . . . . . . . . . 45

3.7 Considerações Finais . . . . . . . . . . . . . . . . . . . 46

4 Predição da Estrutura Terciária de Proteínas $\quad 49$

4.1 Modelagem por Homologia . . . . . . . . . . . . . . . . . . . . . 51

4.2 Modelagem por "Threading" . . . . . . . . . . . . . . . . . 52

4.3 Modelagem "Ab initio" . . . . . . . . . . . . . . . . . . . . . 53

4.3.1 Abordagens com Algoritmos Evolutivos . . . . . . . . . . . . 54

4.3.2 Abordagens com Algoritmos Evolutivos Multi-Objetivo . . . . . . . 59

4.4 Modelagem Semi Ab inito . . . . . . . . . . . . . . . . . . . 60

4.5 Considerações Finais . . . . . . . . . . . . . . . . . . . . 61

5 AEs para Predição de Estruturas de Proteínas $\quad 63$

5.1 AE Mono-Objetivo . . . . . . . . . . . . . . . . . . . . 64

5.1 .1 População Inicial . . . . . . . . . . . . . . . . . . . . . . 64

5.1 .2 Operação de Crossover . . . . . . . . . . . . . . . . 65

5.1 .3 Operação de Mutação . . . . . . . . . . . . . . . . . 67

5.1 .4 Seleção . . . . . . . . . . . . . . . . . . . . . 69

5.1 .5 Convergência . . . . . . . . . . . . . . . 70

5.2 AE Multi-Objetivo . . . . . . . . . . . . . . . 70

5.3 AE Combinatório . . . . . . . . . . . . . . . . . . . 71

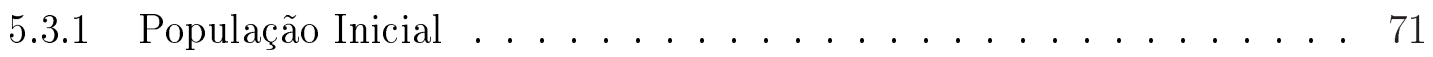

5.3 .2 Operação de Crossover . . . . . . . . . . . . . . . . . . . . . . . . . . . . . . . . . . . . . . 72

5.3 .3 Operação de Mutação . . . . . . . . . . . . . . . . . . . . 73

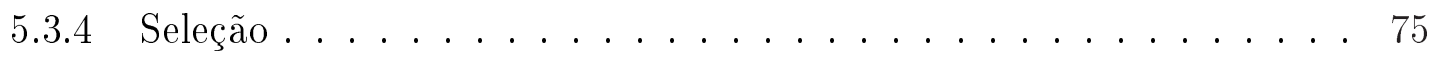

5.4 Função de Avaliação . . . . . . . . . . . . . . . . . . . . 76

5.4.1 Energia de Comprimento de Ligação . . . . . . . . . . . . . 77

5.4 .2 Energia de ângulo de Ligação . . . . . . . . . . . . . . . . . 79

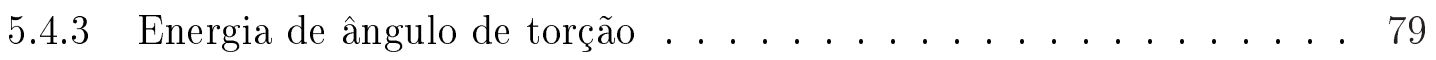

5.4 .4 Energia Urey-Bradley . . . . . . . . . . . . . . . . . . . . . . . 81

5.4 .5 Energia Imprópria . . . . . . . . . . . . . . . . . . . . . . . . . . . . . . . . . . . . . . . 81

5.4 .6 Energia de van der Waals . . . . . . . . . . . . . . . . 82

5.4 .7 Energia Eletrostática ou de Carga . . . . . . . . . . . . . . . . . . 84

5.5 Considerações Finais . . . . . . . . . . . . . . . . . . . 85

6 Resultados Experimentais $\quad 87$

6.1 Avaliação dos Resultados . . . . . . . . . . . . . . . . . 88

6.2 Casos de Teste e Resultados . . . . . . . . . . . . . . . . . . . . 88

6.2.1 Testes e Resultados do AE Mono-Objetivo . . . . . . . . . . . . . . 90 
6.2.2 Testes e Resultados do AE Combinatório com Saídas do AE MonoObjetivo . . . . . . . . . . . . . . . . . . 95

6.2.3 Testes e Resultados do AE Multi-Objetivo . . . . . . . . . . . . . . 97

6.2.4 Testes e Resultados do AE Combinatório com Saídas do AE MultiObjetivo . . . . . . . . . . . . . . 103

7 Conclusões $\quad 107$ 7.1 Trabalhos Futuros . . . . . . . . . . . . . . . . . 108

$\begin{array}{ll}\text { Referências Bibliográficas } & 109\end{array}$

$\begin{array}{ll}\text { A Exemplo do arquivo de Parâmetros } & 121\end{array}$ 


\section{Capítulo \\ 1 \\ Introdução}

s processos de busca por novas drogas e cura de doenças genéticas têm sido amplamente investigados nos dias de hoje. É essencial para esses processos o entendimento das funções das proteínas. O problema do dobramento de proteínas consiste basicamente em, a partir de uma seqüência de aminoácidos, determinar sua estrutura tridimensional nativa, que é fundamental para a compreensão da função da proteína. O custo para determinar uma estrutura protéica é de aproximadamente US\$ 100.000 utilizando técnicas experimentais (Blundell and Mizuguchi, 2000). Uma estimativa conservadora indica que são necessárias 1.000 proteínas alvo para investigar a cura de uma doença genética, o que implica em US\$100.000.000 para iniciar o processo de desenvolvimento de uma nova droga. Portanto, o desenvolvimento de meios eficazes para determinar a estrutura tridimensional das proteínas possui impactos sociais marcantes.

A estrutura terciária de proteínas tem sido determinada confiavelmente utilizando-se os métodos de cristalografia de raio-X e ressonância nuclear magnética (Baxevanis and Ouellette, 2001). Esta última tem sua aplicação restringida pelo tamanho da proteína, enquanto a primeira requer grande tempo de processamento laboratorial com largo custo, além de profissionais especializados para a interpretação dos mapas de elétrons obtidos no processo. A obtenção de cristais, necessários para aplicação do método cristalográfico, pode ser um processo complexo para certas proteínas. Além disso, nem sempre é possível a obtenção do cristal para todas as proteínas e a obtenção dos cristais também pode ser afetada por fatores externos como a ação da gravidade.

Por outro lado, a determinação da seqüência de aminoácidos de um proteína em labora- 
tório é fácil e, relativamente, pouco dispendiosa. No entanto, os procedimentos existentes para a determinação da estrutura tridimensional a partir da seqüência de aminoácidos não tem produzido resultados considerados adequados. Neste contexto, tem-se investigado diversos algoritmos computacionais para resolução desse problema.

Os métodos para determinação da estrutura de proteínas (DEP) a partir da seqüência de aminoácidos são divididos em duas linhas: métodos baseados em conhecimento (Baxevanis and Ouellette, 2001) e métodos Ab initio (Khimasia and Coveney, 1997). Os métodos baseados em conhecimento têm sido largamente empregados, porém possuem uma série de limitações como: dependem de grandes bancos de dados de estruturas de proteínas previamente determinadas, controle da redundância de informações, problemas de alinhamento de seqüências, necessidade de métodos computacionais eficientes que avaliem a similaridade entre estruturas, determinação da hierarquia de homologia estrutural, entre outros.

Por outro lado, os métodos $A b$ initio não possuem as restrições dos métodos baseados em conhecimento, dependendo unicamente da seqüencia de aminoácidos. Os métodos $A b$ initio baseiam-se no princípio de que as proteínas dobram-se em um estado onde sua energia potencial ou sua energia livre é mínima. A energia de uma proteína em função das posições dos seus átomos pode ser calculada utilizando modelos de campo de forças. A energia calculada por um campo de forças pode ser minimizada e, dessa maneira, pode-se encontrar qual é o estado de mínima energia, prevendo então, qual a forma tridimensional da proteína a partir de sua seqüência de aminoácidos. Portanto, a solução desse problema pode ser mapeada em um problema de otimização de uma função potencial, que descreva a interação entre os átomos componentes das proteínas.

Dentre as técnicas $A b$ initio que têm sido investigadas, os Algoritmos Evolutivos (AEs) têm apresentado resultados relevantes. Os AEs (Fogel, 1994; Carvalho et al., 2004; Khimasia and Coveney, 1997) são ferramentas poderosas de otimização inspiradas na evolução natural e que têm sido aplicadas a vários problemas nas mais diversas áreas do conhecimento humano. Nos AEs é simulada a evolução de uma população de indivíduos que são possíveis soluções para o problema. Essas possíveis soluções evoluem de maneira que as melhores soluções encontradas (indivíduos mais adaptados) possuem maior probabilidade de sobreviver ou transmitir suas características para gerações futuras. Pode-se utilizar os AEs para otimizar a energia das proteínas. Para tanto, são criados conjuntos de estruturas de proteínas que concorrem entre si durante a evolução. As que são mais adaptadas (possuem menor energia) têm uma probabilidade maior de sobreviver. Durante a simulação da evolução, as estruturas de menor energia devem prevalecer, levando-nos a encontrar 
estruturas de proteínas com a energia minimizada.

Esta dissertação de mestrado investiga a aplicação de AEs para DEP por meio da minimização da energia potencial. Em geral, propostas de AEs para este problema produzem resultados satisfatórios para classes específicas de proteínas com tamanho reduzido (algumas dezenas de aminoácidos). Este trabalho investiga a elaboração de uma abordagem evolutiva que possa trabalhar com quantidades maiores de resíduos e que não possua o seu domínio restrito a algumas classes de proteínas. Para isso, serão pesquisadas diversas abordagens evolutivas existentes na literatura, operadores de reprodução e formas de codificação de AEs.

O Capítulo 2 introduz os principais conceitos de Computação Evolutiva. O Capítulo 3 apresenta as proteínas e suas principais características. O Capítulo 4 apresenta as principais técnicas para o problema de DEP. O Capítulo 5 apresenta a proposta investigada para o problema de DEP. Os casos de teste utilizados e os resultados obtidos podem ser vistos no Capítulo 6. O Capítulo 7 apresenta as conclusões e sugestões de trabalhos futuros. 


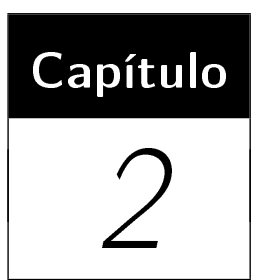

\section{Computação Evolutiva}

$\mathcal{A}$

lgoritmos de computação evolutiva (CE) têm sido empregados em diversas áreas como: ciências naturais, engenharia, biologia e ciência da computação.

A CE é um ramo da Ciência da Computação que propõe um paradigma alternativo para o processamento de dados convencional. Uma vantagem desse paradigma é não exigir o conhecimento prévio sobre como encontrar a solução para um problema, nem requer uma modelagem matemática formal do mesmo (Farmer et al., 1983; Goldberg and Holland, 1988).

Os primeiros trabalhos relacionados a CE surgiram nos anos 50 (Campbell, 1956; Friedman, 1956, 1959). Esses baseiam-se nos princípios da simulação dos processos da Teoria da Evolução (Darwin, 1859; Silva Junior and Sasson, 2003) (ver Seção 2.2). O objetivo fundamental desses algoritmos não é reproduzir os fenômenos que ocorrem na natureza, mas sim inspirar-se neles para solucionar problemas, principalmente na área de otimização. Como muitos problemas de engenharia e de outras áreas podem ser modelados como problemas de otimização (Michalewicz and Fogel, 2004), a CE possui um escopo de abordagem amplo.

Este Capítulo introduz os principais conceitos de CE. A Seção 2.1 relata as características que tornam os algoritmos de $\mathrm{CE}$ alternativas relevantes para diversas áreas do conhecimento. A Seção 2.2 apresenta as bases biológicas da CE. A Seção 2.3 descreve uma das abordagens mais utilizadas em CE, os Algoritmos Genéticos. A Seção 2.4 apresenta uma visão geral sobre CE. Na Seção 2.5 são apresentados os AEs multi-objetivos, 
em especial o modelo NSGA-II. A Seção 2.6 mostra as considerações finais.

\subsection{Motivação}

As motivações para o emprego dos algoritmos de CE em diversas áreas são apresentadas a seguir. Uma das primeiras motivações foi a simulação computacional de sistemas evolutivos para investigar conceitos da Teoria da Evolução da Biologia, ou seja, a CE pode auxiliar na compreensão dos processos evolutivos naturais (Michalewicz and Fogel, 2004).

Outra motivação importante para o desenvolvimento da CE é a capacidade dos algoritmos de CE em lidar com problemas complexos para os quais não é possível, ou é difícil, obter uma descrição detalhada do problema ou não se consegue impor restrições muito fortes. Essas duas condições são necessárias para a utilização dos algoritmos convencionais de solução dedicados, que podem ser mais eficientes. Por exemplo, para se utilizar um algoritmo de programação linear (Luenberger, 1984) é necessário que a função objetivo seja linear; por outro lado, os algoritmos de busca baseados em gradiente (Luenberger, 1984) requerem que a função objetivo seja diferenciável e, além disso, que a derivada possa ser calculada com baixo custo computacional. Quando ocorre a ausência destas características os algoritmos da CE surgem como uma das poucas alternativas para se encontrar uma solução adequada para o problema (Michalewicz and Fogel, 2004).

A possibilidade de recorrer à técnicas de solução adaptativas, ou seja, técnicas capazes de manter o desempenho mesmo quando o ambiente é não estacionário ${ }^{1}$, é outra motivação para a utilização de CE. Isso deve-se ao fato de que não é necessário reiniciar todo o processo de busca da solução quando ocorre uma pequena mudança na especificação do problema, visto que as técnicas evolutivas permitem que refinamentos possam ser obtidos a partir da solução atual.

A capacidade de gerar soluções suficientemente apropriadas em um tempo de computação suficientemente pequeno junto a problemas de alta complexidade, é outra das motivações para a utilização da CE. Enquanto técnicas convencionais de obtenção da solução ótima necessitam uma quantidade inatingível de recursos computacionais para problemas intratáveis ${ }^{2}$, os algoritmos da CE são capazes de fornecer soluções aproximadas, ou ótimas, necessitando relativamente poucos recursos computacionais.

\footnotetext{
${ }^{1}$ Quando o problema está sujeito a pequenas variações em suas especificações a qualquer momento.

${ }^{2}$ Problemas para os quais não existe algoritmo que execute todas as instâncias em tempo polinomial. Tempo polinomial significa que o tempo de computação, $c * t(n)$, é limitado por uma função polinomial do tamanho do problema, $n$ e $c$ uma constante positiva. Formalmente $t(n)=O\left(n^{k}\right)$, onde $k$ é uma constante.
} 
A possibilidade de incorporar conhecimento em um computador, sem a necessidade de programá-lo para isso, é outra característica importante da CE, ou seja, sem a necessidade de recorrer ao conhecimento humano expresso, por exemplo, por meio de uma base de regras. A CE possibilita que o computador ganhe proficiência na execução de tarefas antes restritas a especialistas humanos, simplesmente com a realização de ações e recebendo a realimentação acerca das conseqüências das ações tomadas, única fonte de informação para a evolução do processo de aprendizagem (Michalewicz, 1996).

\subsection{Base Biológica}

A CE baseia-se em mecanismos evolutivos encontrados na natureza, tais como a autoorganização e o comportamento adaptativo (Goldberg and Holland, 1988). Esses mecanismos foram descobertos e formalizados por Darwin em sua Teoria da Evolução Natural, segundo a qual a vida na terra é o resultado de um processo de seleção pelo meio ambiente dos mais aptos e adaptados, tendo estes indivíduos mais oportunidades de reproduziremse e de produzir indivíduos cada vez mais aptos. A diversidade da vida, associada ao fato de que todos os seres vivos compartilham uma bagagem genética comum, é um exemplo das possibilidades do mecanismo de evolução natural em diversificar as espécies. Esta Seção apresenta os principais conceitos dessa teoria.

\subsubsection{Teoria da Evolução}

A teoria da evolução foi proposta por Charles Darwin (Darwin, 1859) na década de 1850 e desde então é a principal idéia unificadora das diversas áreas da Biologia, distingüindo os sistemas biológicos dos demais sistemas físicos e químicos.

A teoria de Darwin fundamenta-se em suas observações durante sua viagem a bordo do navio Beagle. Esta teoria tem como um de seus princípios o conceito de seleção natural, o qual afirma que o meio atua sobre os indivíduos e seleciona os mais adaptados ao ambiente para sobreviver, pois as populações não podem crescer demais. São considerados indivíduos adaptados ao ambiente aqueles que conseguem sobreviver e deixar descendentes.

Ao analisar as espécies encontradas durante sua viagem e também fósseis de antigas espécies, Darwin observou que os indivíduos de uma mesma espécie apresentavam diferenças e que as características dos indivíduos diferentes mais adaptados ao ambiente permaneciam na população. 
Darwin não conseguia explicar genéticamente como a variabilidade dos indivíduos surgia e era transmitida para os descendentes. Foi então, que a partir de 1900 com base nos estudos de Gregor Mendel (Mendel.G., 1865), descobriu-se a ligação entre os mecanismos de herança e o cromossomo, o que deu origem à genética.

Em 1940 com o auxílio da teoria genética os pesquisadores chegaram à Teoria Sintética da Evolução ou Neodarwinismo (Silva Junior and Sasson, 2003) baseada nos conceitos de recombinação gênica e mutação. A recombinação gênica é responsável pela transmissão das características dos pais para os filhos. A mutação é responsável pelo surgimento da diversidade nos indivíduos da população, com o surgimento de novas características que, se forem benéficas tornam os indivíduos mais aptos e adaptados facilitando a geração de descendentes com tais características; caso contrário essas características tendem a ser eliminadas. Esse processo é denominado de seleção natural.

\subsection{Algoritmos Genéticos}

Os Algoritmos Genéticos (AGs) foram introduzidos por John Holland na década de 1960 (Holland, 1975), na Universidade de Michigan, com o objetivo de estudar formalmente os conceitos de adaptação que ocorrem na natureza, formalizá-los matematicamente, e desenvolver sistemas artificiais (simulados em computador) que mimetizam os mecanismos originais encontrados em sistemas naturais.

O AG proposto por Holland é um método que consiste em modificar uma população (conjunto de indivíduos representando as soluções candidatas codificadas na forma de cromossomos) inicial em uma nova população utilizando a seleção natural e os operadores genéticos: recombinação gênica (ou crossover) e mutação. Os AGs utilizam uma terminologia originada da Teoria da Evolução Natural e da genética. Um indivíduo da população é representado por um único cromossomo, que contém a codificação (genótipo) de uma possível solução do problema (fenótipo). Cromossomos são geralmente implementados na forma de listas de atributos, vetores ou strings, onde cada atributo é conhecido como gene, e os possíveis valores que um determinado gene pode assumir são denominados alelos. No AG proposto por Holland um cromossomo é geralmente representado por uma string binária, ou seja, uma string de zeros e uns.

O processo de evolução executado por um AG possui características de um procedimento de busca em um espaço de soluções potenciais para o problema. No entanto, segundo Michalewicz (1996), esta busca requer um equilíbrio entre dois objetivos aparentemente conflitantes: o aproveitamento das melhores soluções e a exploração do espaço 
de busca. AGs constituem, assim, uma classe de métodos de busca de propósito geral que apresentam um balanço notável entre aproveitamento de melhores soluções e exploração do espaço de busca.

Embora apresentem etapas não-determinísticas em seu desenvolvimento, os AGs não são métodos de busca puramente aleatórios, pois combinam variações aleatórias com seleção, polarizada pelos valores de adequação (fitness) atribuído a cada indivíduo. Uma propriedade importante dos AGs é que esses mantêm uma população de soluções candidatas enquanto que outros métodos alternativos, como simulated annealing (Aarts and Korst, 1989), analisam um único ponto no espaço de busca a cada instante. Além disso, os AGs possuem um paralelismo implícito decorrente da avaliação independente de cada uma das cadeias de bits que compõem os cromossomos, ou seja, pode-se avaliar a viabilidade de um conjunto de soluções para o problema.

O processo de busca é, portanto, multi-direcional, com a manutenção de soluções candidatas que representam a busca em várias partes do domínio e com troca de informações entre essas soluções. A cada geração, soluções relativamente "boas" reproduzem-se mais freqüentemente, enquanto que soluções relativamente "ruins" tendem a ser eliminadas. Para fazer a distinção entre diferentes soluções é empregada a função de avaliação (de adaptabilidade ou fitness) que simula o papel da pressão exercida pelo ambiente sobre o indivíduo. O Algoritmo 2.1 descreve um AG típico:

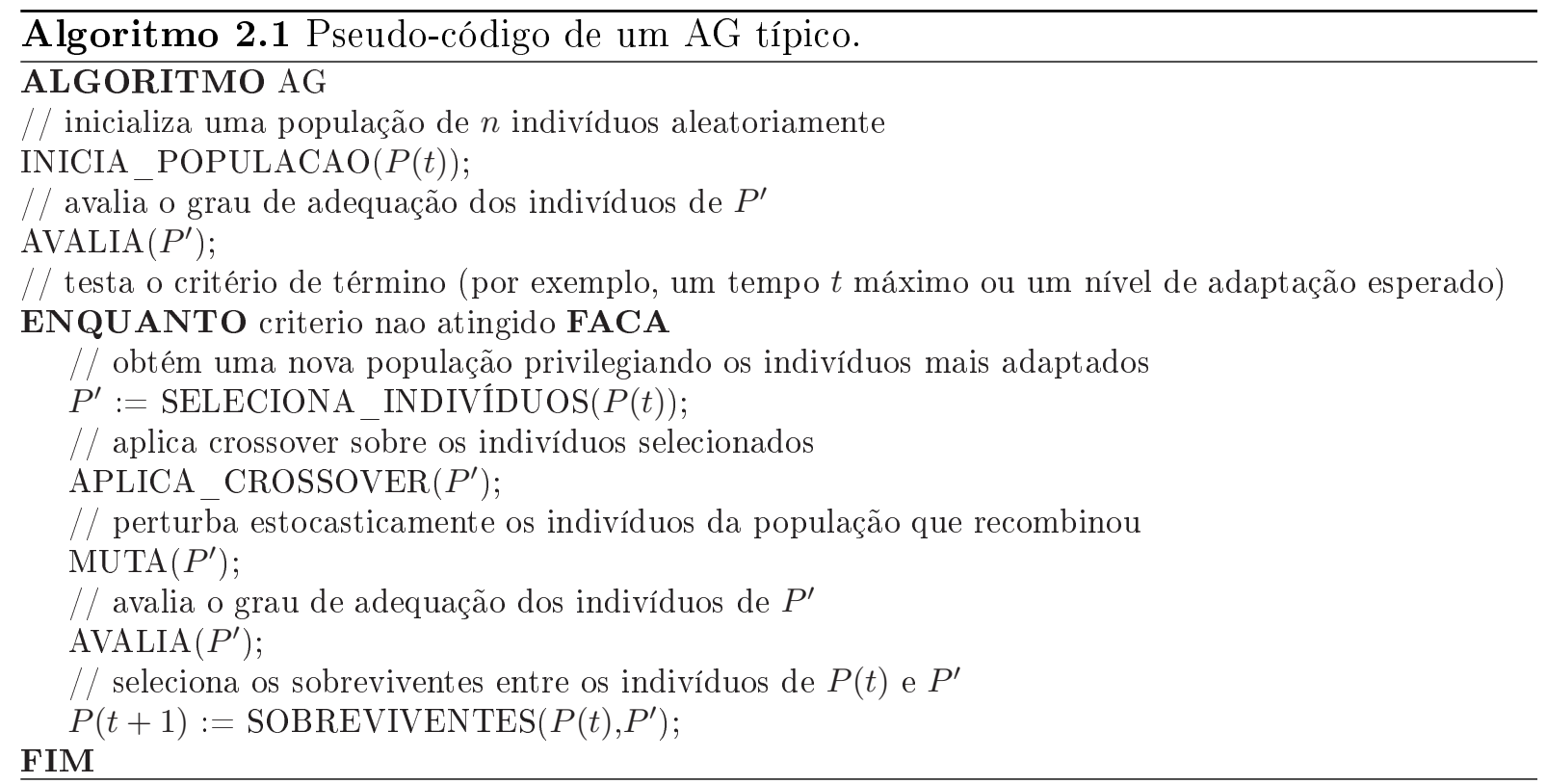

No desenvolvimento de um AG para um problema particular deve-se especificar os seguintes componentes: 
- representação genética para soluções potenciais (etapa de codificação);

- procedimento para criar uma população inicial;

- função de avaliação para classificar as soluções em termos de sua adaptação ao ambiente (sua capacidade de resolver o problema);

- definir os operadores genéticos com base na codificação (representação dos dados referentes ao indivíduo) utilizada;

- valores para os diversos parâmetros do AG, tamanho da população, probabilidades de aplicação dos operadores genéticos e outros.

\subsubsection{Codificação dos Indivíduos}

No AG clássico proposto por Holland (1975), os indivíduos da população são codificados em strings binárias de tamanho fixo. A grande motivação para o emprego da codificação binária está na Teoria de Esquemas (Holland, 1992), utilizada para justificar a eficiência dos AGs. Segundo Holland, (1992) a representação binária maximiza o paralelismo implícito inerente ao AG.

Entretanto, em diversas aplicações práticas a codificação binária leva a um desempenho insatisfatório, por exemplo em problemas de otimização numérica com parâmetros reais, AGs com codificação inteira ou de ponto flutuante são mais eficientes (Michalewicz, 1996; Deb, 2001). Tanto Michalewicz (1996) quanto Deb (2001) apresentam resultados de comparações do desempenho de AGs com codificação binária e com ponto flutuante. Os resultados apresentados revelam superioridade da codificação em ponto flutuante.

Michalewicz (1996) argumenta que a representação binária não é adequada quando o espaço de busca é de alta dimensão. Porém esta argumentação não é muito aceita na literatura sobre AGs. Segundo Fogel (1994) o espaço de busca por si só (sem considerar a escolha da codificação) não determina a eficiência do AG. Espaços de busca de alta dimensão podem às vezes ser explorados eficientemente, enquanto que espaços de busca de dimensão reduzida podem apresentar dificuldades significativas. Outro problema encontrado com a codificação binária ocorre quando o espaço de busca do problema é contínuo, podendo ocorrer Hamming cliffs com certas strings, por exemplo 01111 e 10000, onde a transição para uma solução vizinha no espaço números de ponto flutuante requer a alteração de muitos bits da string (Deb, 2001). Os Hamming cliffs presentes na codificação binária causam o atraso para uma busca gradual nos espaços de busca contínuos. Outra dificuldade no caso de problemas com espaços de busca contínuos é a incapacidade de 
armazenar qualquer precisão arbitrária na solução ótima, quando a codificação binária é utilizada é necessário escolher a priori o tamanho da string para que o AG seja capaz de armazenar uma certa precisão na solução. Quanto mais precisão for requerida, então maior será o tamanho da string. Para grandes strings, necessita-se uma população grande, aumentando assim a complexibilidade do algoritmo, tornando-o inviável (Deb, 2001). Deb (2001) apresenta um operador de crossover para AGs com codificação de ponto flutuante que simula o princípio do operador de crossover de um ponto para AGs utilizando a codificação binária.

A codificação é uma das etapas mais críticas na definição de um AG. A definição inadequada da codificação pode acarretar diversos problemas, entre esses um dos mais importantes é problemas de convergência prematura ${ }^{3}$ do AG. A estrutura de um cromossomo deve representar uma solução como um todo e deve ser a mais simples possível.

Em uma série de problemas de otimização com restrição, a codificação adotada pode fazer com que indivíduos modificados por crossover/mutação sejam inválidos. Nesses casos, cuidados especiais devem ser tomados na definição da codificação e/ou dos operadores (Michalewicz, 1996).

\subsubsection{Definição da População Inicial}

O método geralmente utilizado na criação da população é a inicialização aleatória dos indivíduos. Se algum conhecimento inicial a respeito do problema estiver disponível, pode ser utilizado na inicialização da população. Por exemplo, no caso de codificação binária, se é sabido que a solução final vai apresentar mais 0 's do que 1's, então esta informação pode ser utilizada, mesmo que não se saiba exatamente a proporção. Já em problemas com restrições, deve-se tomar cuidado para não gerar indivíduos inválidos na etapa de inicialização.

\subsubsection{Operadores Genéticos}

Os operadores genéticos mais freqüentemente utilizados em AGs são o crossover e a mutação. Esta Seção, apresenta os principais aspectos relacionados a esses operadores.

\footnotetext{
${ }^{3} \mathrm{~A}$ convergência prematura ocorre quando indivíduos relativamente adaptados, contudo não ótimos, rapidamente dominam a população fazendo com que o AG convirja para um máximo ou mínimo local. Este problema, pode ocorrer devido a uma formulação inadequada do problema.
} 


\section{Operador de Crossover}

O operador de crossover ou recombinação cria novos indivíduos por meio da combinação de dois ou mais indivíduos, chamados pais. A idéia intuitiva por trás do operador de crossover é a troca de informação entre diferentes soluções candidatas. No AG clássico é atribuída uma probabilidade fixa de ocorrer crossover aos indivíduos da população.

O tipo de crossover mais comumente empregado é o crossover de um ponto. Para a aplicação deste, são selecionados dois indivíduos (pais) e a partir de seus cromossomos são gerados dois novos indivíduos (filhos). Para gerar os filhos, seleciona-se um mesmo ponto de corte aleatoriamente nos cromossomos dos pais então, os segmentos de cromossomo criados a partir do ponto de corte são trocados. Considere, por exemplo, dois indivíduos selecionados como pais a partir da população inicial de um AG e suponha que o ponto de corte escolhido encontra-se entre as posições três e quatro dos cromossomos dos pais:

\begin{tabular}{|l|l|l|l|l|l|l|l|l|l|l|l|}
\hline 1 & 0 & 1 & 0 & 0 & 1 & e 0 & 1 & 1 & 1 & 0 & 1 \\
\hline
\end{tabular}

Após o crossover, tem-se os seguintes indivíduos filho:

\begin{tabular}{|l|l|l|l|l|l|l|l|l|l|l|l|}
\hline 1 & 0 & 1 & 1 & 0 & 1 & e 0 & 1 & 1 & 0 & 0 & 1.
\end{tabular} .

Muitos outros tipos de crossover têm sido propostos na literatura. Uma extensão simples do crossover de um ponto é o crossover de dois pontos, onde dois pontos de corte são escolhidos e o material genético entre eles é trocado. Considere dois indivíduos selecionados como pais e os pontos de corte escolhidos entre as posições dois e três e, entre as posições cinco e seis dos cromossomos pais:

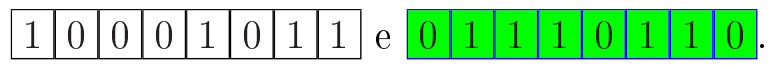

Aplicando o crossover, obtem-se os seguintes indivíduos filhos:

\begin{tabular}{|l|l|l|l|l|l|l|l|l|l|l|l|l|l|l|l|}
\hline 1 & 0 & 1 & 1 & 0 & 0 & 1 & 1 \\
\hline
\end{tabular}

Outro tipo de crossover muito comum é o crossover uniforme (Sywerda, 1989): para cada bit no primeiro filho é decidido (com alguma probabilidade fixa $p$ ) qual dos pais vai contribuir com seu valor para aquela posição. Como o crossover uniforme troca bits ao invés de segmentos de bits, esse pode combinar características independentemente da sua posição no cromossomo. No entanto, não há nenhum operador de crossover que claramente apresente um desempenho superior aos demais. Uma conclusão é que um operador de crossover que é particularmente eficiente para uma determinada classe de problemas pode ser ineficiente para outras.

Os operadores de crossover descritos até aqui também podem ser utilizados em cromossomos com codificação em ponto flutuante. Entretanto, existem operadores de crossover especialmente desenvolvidos para uso com codificação em ponto flutuante. Um exemplo é o chamado crossover aritmético (Michalewicz, 1996). Este operador é definido como uma 
combinação linear de dois cromossomos: sejam $x^{1}$ e $x^{2}$ dois indivíduos selecionados para crossover, então os dois filhos resultantes serão $x^{1^{\prime}}=a x^{1}+(1-a) x^{2}$ e $x^{2^{\prime}}=(1-a) x^{1}+a x^{2}$ onde $a$ é um número aleatório pertencente ao intervalo [0,1]. Este operador é particularmente apropriado para problemas de otimização numérica com restrições, onde a região factível é convexa. Se $x^{1}$ e $x^{2}$ pertencem à região factível, combinações convexas de $x^{1}$ e $x^{2}$ serão também factíveis. Assim, garante-se que o crossover não gera indivíduos inválidos para o problema em questão (Deb, 2001).

Outro exemplo de crossover para a codificação de ponto flutuante é o crossover de mistura (BLX - $\alpha$ ) (Eshelman and Schaffer, 1993). Considere-se $x^{1}$ e $x^{2}$ dois indivíduos selecionados para crossover e assume-se que $x_{i}^{1}<x_{i}^{2}$ onde $i$ representa o $i$-ésimo gene. $\mathrm{O}$ BLX - $\alpha$ escolhe aleatoriamente uma solução no intervalo $\left[x_{i}^{1}-\alpha\left(x_{i}^{2}-x_{i}^{1}\right), x_{i}^{2}+\alpha\left(x_{i}^{2}-x_{i}^{1}\right)\right]$. Um número de problemas teste têm reportado que o melhor valor para $\alpha$ é $\alpha=0.5$ sobre qualquer outro valor escolhido. Se a diferença entre os pais for pequena a diferença entre os pais e os filhos também será pequena e vice versa. Esta propriedade permite que este operador execute uma busca pelo espaço inteiro, no início, e também execute uma busca localizada quando a população tende a convergir para uma região do espaço de busca.

Outros operadores de crossover para codificação em ponto flutuante são: crossover de simulação binária, operador de recombinação Fuzzy, crossover de distribuição uniforme, crossover simplex e outros (Deb, 2001).

\section{Operador de Mutação}

O operador de mutação modifica aleatoriamente um ou mais genes de um cromossomo. A probabilidade de ocorrência de mutação em um gene é denominada taxa de mutação. Usualmente, são atribuídos valores pequenos para a taxa de mutação. A idéia intuitiva do operador de mutação é criar uma variabilidade extra na população, mas sem destruir o progresso já obtido com a busca.

Considerando codificação binária, o operador de mutação padrão simplesmente troca o valor de um gene em um cromossomo (Holland, 1992). Assim, se um gene selecionado para mutação tem valor um, o seu valor passará a ser zero após a aplicação da mutação, e vice versa. Por exemplo, considere o seguinte indivíduo:

\section{\begin{tabular}{|l|l|l|l|l|l|l|l|}
\hline 1 & 0 & 1 & 0 & 0 & 1 & 1 & 1 \\
\hline
\end{tabular}}

Após a aplicação do operador de mutação obtém-se o seguinte indivíduo:

\begin{tabular}{|l|l|l|l|l|l|l|l|}
\hline 1 & 0 & 1 & 0 & 0 & 0 & 1 & 1 \\
\hline
\end{tabular}

No caso de problemas com codificação em ponto flutuante, os operadores de mutação mais populares são a mutação uniforme e a mutação gaussiana (Michalewicz and 
Schoenauer, 1996). O operador para mutação uniforme seleciona aleatoriamente um componente $k \in\{1,2, \ldots, n\}$ do cromossomo $x=\left[x_{1}, \ldots, x_{k}, \ldots, x_{n}\right]$ e gera um indivíduo $x^{\prime}=\left[x_{1}, \ldots, x_{k}^{\prime}, \ldots, x_{n}\right]$, onde $x_{k}^{\prime}$ é um número aleatório (com distribuição de probabilidade uniforme) amostrado no intervalo $[L B, U B]$, onde $L B$ e $U B$ são, respectivamente, os limites inferior e superior para o valor do alelo $x_{k}$. No caso da mutação gaussiana, todos os componentes de um cromossomo $x=\left[x_{1}, \ldots, x_{k}, \ldots, x_{n}\right]$ são modificados na forma:

$$
x^{\prime}=x+N(0, \sigma)
$$

onde $N(0, \sigma)$ (Michalewicz and Schoenauer, 1996) é um vetor de variáveis aleatórias gaussianas independentes, com média zero e desvio padrão $\sigma$. Outro operador de mutação, especialmente desenvolvido para problemas de otimização com restrições e codificação em ponto flutuante, é a chamada mutação não-uniforme, destinada a realizar pequenos ajustes necessários para atingir a solução ótima junto aos indivíduos da população. Esse e outros exemplos de operadores de mutação para problemas de otimização numérica podem ser encontrados em Michalewicz (1996) e Michalewicz e Schoenauer (1996).

\subsubsection{Seleção dos Indivíduos para a Próxima Geração}

O AG clássico utiliza um esquema de seleção de indivíduos para a próxima geração chamado técnica da roleta (Michalewicz, 1996). A técnica da roleta atribui a cada indivíduo de uma população uma probabilidade de passar para a próxima geração que é proporcional ao fitness do indivíduo e à somatória do fitness de todos os indivíduos da população. Assim, quanto maior o fitness de um indivíduo, maior a probabilidade deste passar para a próxima geração. Sendo assim, a seleção de indivíduos pela técnica da roleta pode fazer com que o melhor indivíduo da população seja perdido, ou seja, não passe para a próxima geração. Uma alternativa é escolher como solução o melhor indivíduo encontrado em todas as gerações do algoritmo. Pode-se, também, manter sempre o melhor indivíduo da geração atual na geração seguinte, estratégia essa conhecida como seleção elitista (Fogel, 1994; Michalewicz, 1996).

Outro exemplo de mecanismo de seleção é a baseada em rank (Bäck et al., 1997). Esta estratégia utiliza as posições dos indivíduos ordenados de acordo com o fitness para determinar a probabilidade de seleção. Podem ser usados mapeamentos lineares ou nãolineares para determinar a probabilidade de seleção.

Um outro mecanismo de seleção é a seleção por Torneio, onde um número $m$ de indivíduos da população é escolhido aleatoriamente para formar uma sub-população temporária. 
Deste grupo, o melhor indivíduo é selecionado. Assim, escolhe-se cada indivíduo que irá compor o grupo de $N$ indivíduos selecionados. A seguir, são apresentados alguns outros possíveis mecanismos de seleção:

- Seleção por diversidade: são selecionados os indivíduos mais diversos da população;

- Seleção bi-classista: são selecionados os P\% melhores indivíduos e os (100 - P)\% piores indivíduos;

- Seleção aleatória: são selecionados aleatoriamente $n$ indivíduos da população. Podese subdividir este mecanismo de seleção em (Michalewicz, 1996):

- Salvacionista: seleciona-se o melhor indivíduo e os outros aleatoriamente;

- Não-salvacionista: seleciona-se aleatoriamente todos os indivíduos.

Os mecanismos de seleção apresentados podem ser empregados para determinar também os indivíduos que irão sofrer crossover e mutação. O número de indivíduos selecionados para crossover pode ser bem menor que o total de indivíduos da população, indicando que só alguns terão maior probabilidade de gerar descendentes em grande número.

\subsection{Outras Técnicas Evolutivas}

Além dos AGs outros algoritmos foram desenvolvidos na segunda metade do século XX seguindo os princípios evolutivos. Esses algoritmos são chamados de Algoritmos Evolutivos (AEs) e são estudados na área de pesquisa de CE.

No contexto histórico, cinco abordagens para sistemas baseados em evolução foram paralelamente desenvolvidas. As principais diferenças entre elas dizem respeito aos operadores de reprodução empregados, estruturas de dados utilizadas para codificar os indivíduos, métodos para criar a população inicial e métodos para selecionar os indivíduos para a próxima geração. As principais abordagens em computação evolutiva são:

- algoritmos genéticos

- estratégias evolutivas (EE)

- programação evolutiva (PE)

- sistemas classificadores (SC)

- programação genética $(P G)$ 


\subsubsection{Estratégias Evolutivas}

As Estratégia Evolutivas (EE) foram desenvolvidas para resolução de problemas técnicos de otimização em engenharia e problemas contínuos de otimização paramétrica. A primeira abordagem foi proposta por Rechenberg, (1965) e Schwefel, (1965) e é denominda EE- $(1+1)$, onde um pai gera um novo indivíduo e ambos competem pela sobrevivência.

Nas EEs, um indivíduo é representado por um par de vetores reais da forma $v=(x, \sigma)$, onde $x$ representa o ponto de busca no espaço e $\sigma$ o vetor de desvio padrão associado. Nas versões atuais, os descendentes são obtidos submetendo-se os indivíduos da geração a dois operadores: cruzamento e mutação. O cruzamento é aleatório e a mutação ocorre tipicamente através de uma perturbação Gaussiana de média nula e desvio padrão unitário, porém outros tipos de mutação são possíveis (Yao and Liu, 1993; Gomes and Saavedra, 1999; Nogueira and Saavedra, 1999). Observa-se que o parâmetro $\sigma$, que determina a mutação de $x$, também está sujeito ao processo de evolução através de mutação. Esta é uma característica fundamental das EEs, que permite o auto-ajuste de seus parâmetros. Assumindo algumas hipóteses, é possível provar que as EE’s convergem ao ótimo global com probabilidade 1, considerando um tempo de busca suficientemente longo.

Na primeira versão das EEs, onde um pai competia com um filho pela sobrevivência, sendo a solução mais pobre descartada, um problema observado era a convergência lenta. Além disso, a busca ponto a ponto possuía a grande probabilidade de estagnar em um ponto de mínimo local. Outras estratégias foram desenvolvidas para tentar solucionar esses problemas e são denominadas estratégias multi-indivíduos, onde a população possui tamanho maior do que 1.

Atualmente as EEs multi-indivíduos possuem dois principais tipos: EE- $(\mu+\lambda)$ e EE$(\mu, \lambda)$. Na primeira, $\mu$ indíviduos reproduzem gerando $\lambda$ descendentes, obtendo uma população temporário de $(\mu+\lambda)$ indivíduos, de onde são escolhidos os $\mu$ indivíduos da próxima geração.

$\mathrm{Na}$ EE- $(\mu, \lambda), \mu$ indivíduos reproduzem gerando $\lambda$ descendentes, com $\mu<\lambda$, sendo que a nova população de $\mu$ indivíduos é selecionada dos $\lambda$ descendentes. Assim, o período de vida de cada indivíduo é de uma geração. Esta EE tem tido bom desempenho para problemas onde o ponto ótimo é em função do tempo, ou em casos em que a função é afetada por ruído. 


\subsubsection{Programação Evolutiva}

A programação evolutiva (PE) foi proposta por Fogel, Owens e Walsh em meados dos anos 60. Utiliza os conceitos de evolução para gerar progressivamente soluções apropriadas em sistemas estáticos ou mesmo que mudam dinâmicamente (Fogel, 1962). Difere dos AGs, pois simula a evolução enfatizando a ligação comportamental entre as populações geradas, mais que a ligação genética.

Os indivíduos são submetidos a diferentes tipos de mutação que simplesmente alteram aspectos da solução de acordo com uma distribuição estatística que pondera variações menores ou maiores conforme a proximidade dos indivíduos do ótimo global.

No processo de seleção dos indivíduos para a próxima geração os descendentes com melhor avaliação são selecionados e comparados com os pais. Se o filho for superior ao pai ele substitui o pai, senão o filho é eliminado e o processo é repetido até que todos os melhores filhos tenham sido comparados. Terminado este processo o filho, que foi superior ao pai, é comparado com o melhor indivíduo da população, se o novo indivíduo for melhor ou igual ao melhor indivíduo, uma nova geração de melhores indivíduos é criada e suas informações genéticas são armazenadas para evitar que o processo evolutivo modifique-as.

\subsubsection{Sistemas Classificadores}

Basicamente, um sistema classificador consiste de uma metodologia para criação e atualização evolutiva de regras (os classificadores) em um sistema de tomada de decisão, que codifica alternativas de ações específicas para as características de um ambiente em determinado instante. Entende-se como "ambiente" modelos de problemas do mundo real, não-estacionários, em geral, para otimização e controle (Michalewicz, 1996).

A interação do sistema classificador com o ambiente ocorre por meio da troca de mensagens. As mensagens do ambiente retratam o seu estado atual. Já as mensagens do sistema classificador retratam ações a serem aplicadas sobre o ambiente.

Existem duas variantes para formação dos classificadores, a abordagem "Pittsburgh", na qual um indivíduo representa a solução para o problema, e a abordagem "Michigan", na qual a solução é dada pela população e não pelos indivíduos da população - existe uma única solução sendo evoluída (Michalewicz, 1996). Como é padrão em regras, os classificadores são compostos por uma parte antecedente e uma consequente.

O processo evolutivo nos sistemas classificadores é feito por meio de um AG, onde os cromossomos são os classificadores codificados na forma de antecedente e consequente. Para a reprodução são aplicados operadores de crossover e mutação. A avaliação dos 
classificadores ocorre por meio da interação do classificador com o ambiente. Os métodos de seleção são os mesmos utilizados em AGs.

\subsubsection{Programação Genética}

Estratégia proposta por Koza (1992), é uma extensão dos AGs que distingui-se por seu particular conjunto de escolhas para a representação, projeto de operadores genéticos e avaliação da função de adequação (Koza, 1992). Tem como objetivo ser uma técnica automática de programação que propicia a evolução de programas de computadores que resolvem (ou aproximadamente resolvem) problemas.

Os indivíduos são codificados na forma de árvores, onde os nós folha contém constantes, variáveis ou parâmetros para a execução de funções e procedimentos. Os nós internos contém operações primárias ou chamadas de funções e procedimentos (Rezende, 2003).

Os operadores de reprodução utilizados são operadores de crossover e mutação específicos para representações por árvores. No crossover partes das árvores são trocadas, o ponto de corte na árvore é escolhido de forma a evitar a criação de operações inválidas. Na mutação o valor de um nó ou subárvore é alterado. Se o nó escolhido para a mutação for um nó interno, este será alterado para ter uma nova operação ou função. No caso de mutação de subárvore a subárvore selecionada é substituída por uma nova subárvore gerada aleatoriamente (Rezende, 2003).

O processo de avaliação ocorre por meio da execução do programa representado pela árvore do índividuo. Se este resolver o problema proposto ou se aproximar da solução dele terá um valor de aptidão elevado; caso contrário, sua aptidão será baixa.

Geralmente, os algoritmos de PG utilizam somente o operador de crossover no processo de evolução das soluções (Rezende, 2003).

\subsection{Algoritmos Evolutivos Multi-Objetivo}

AEs Multi-Objetivo (AEMO) tem sido aplicados para problemas de otimização multiobjetivo, onde tem-se mais de um objetivo a ser minimizado e ou maximizado. Neste caso não existe somente uma solução para o problema, mas sim um conjunto de soluções ótimas, denominado conjunto de Pareto ótimo ou fronteira de Pareto.

O primeiro AEMO implementado foi proposto por Schaffer em 1985 (Schaffer, 1985), e foi denominado VEGA (Vector Evaluated Genetic Algorithm). Nessa proposta Schaffer propõem uma modificação no AGs para avaliar cada objetivo separadamente. Um dos 
problemas do algoritmo proposto por Schaffer é que este não obtém boa diversidade nas soluções da fronteira de Pareto.

Goldberg (1989) criou em procedimento que ordena as soluções baseado no conceito de dominância que fornece um valor de aptidão para uma solução proporcional ao número de soluções que esta domina. Com isto as soluções não dominadas possuem maior aptidão e assim terão maior quantidade de cópias na lista de soluções. Com o objetivo de manter a diversidade das soluções, Goldberg sugeriu a utilização de um método de compartilhamento que calcula o nicho de cada solução dentro da fronteira a que a solução pertence. Com base nas idéias iniciais de Goldberg foram propostos vários modelos de AEMOs.

A principal diferença entre os AEs tradicionais e os AEMOs é o operador de seleção, dado que a comparação entre duas soluções deve realizar-se de acordo com o conceito de dominância de Pareto. Em algumas propostas, como MOGA e SPEA, o valor de aptidão é proporcional à dominância da solução. Em outros métodos, como NPGA, utiliza-se a dominância Pareto e não calcula-se um valor de aptidão.

Os modelos de AEMO são classificador por Deb (2001) em dois tipos:

1. Não-elitistas: compreendem os modelos que como o próprio nome indica, não utilizam alguma forma de elitismo nas suas interações;

2. Elitistas: compreendem os modelos que empregam alguma forma de elitismo. Alguns modelos, como SPEA e PESA, utilizam uma população externa para armazenar as soluções não-dominadas encontradas até o momento. Métodos como NSGA-II combinam a população atual com a população gerada e preservam as melhores soluções de ambas. Um estudo realizado por Zitzler (Zitzler et al., 2000) conclui que o elitismo melhora as soluções encontradas por um modelo de AEMO.

A tabela 2.1 apresenta os principais modelos de AEMO e seus autores.

A seguir será discutido o modelo proposto para o NSGA-II, focalizando suas vantagens, desvantagens e principais contribuíções.

\subsubsection{NSGA-II}

O algoritmo NSGA-II é baseado em um ordenamento elitista por não-dominância (Deb et al., 2000). O NSGA-II trabalha com a população de indivíduos pais $P$ para gerar a população de indivíduos filhos $Q$ como nos AEs convencionais. Na primeira iteração, gera-se uma população $P_{0}$, que é ordenada por não-dominância (1 é o melhor nível, 2 é o segundo melhor nível e assim por diante). A seguir, aplicando-se os operadores de seleção 


\begin{tabular}{||c|c|c||}
\hline \hline Sigla & Nome do Modelo & Autores \\
\hline \hline VEGA & Vector Evaluated Genetic Algorithm & (Schaffer, 1985) \\
\hline WBGA & Weight Based Genetic Algorithm & (Hajela and Lin, 1992) \\
\hline MOGA & Multiple Objective Genetic Algorithm & (Fonseca and Fleming, 1993) \\
\hline NSGA & Non-Dominated Sorting Genetic Algorithm & (Srinivas and Deb, 1994) \\
\hline NPGA & Niched-Pareto Genetic Algorithm & (Horn et al., 1994) \\
\hline PPES & Predator-Prey Evolution Strategy & (Laumanns et al., 1998) \\
\hline REMOEA & Rudoph's Elitist Multi-Objective & (Rudolph, 2001) \\
\hline NSGA-II & Elitist Non-Dominated Sorting Genetic & (Deb et al., 2000) \\
\hline SPEA, & Algorithm & (Zitzler and Thiele, 1998), \\
SPEA-2 & (Zitzler et al., 2001) \\
\hline TGA & Thermodynamical Genetic Algorithm & (Kita et al., 1996) \\
\hline PAES & Pareto-Archived Evolutionary Strategy & (Knowles and Corne, 1999) \\
\hline MONGA-I, & Multi-Objective Messy Genetic Algorithm & (Veldhuizen, 1999) \\
MONGA-II & & (Coello and Pulido, 2001) \\
\hline Micro-GA & Multi-Objective Micro-Genetic Algorithm & (Corne et al., 2000), \\
\hline PESA-I, PESA-II & Pareto Envelope-Base Selection Algorithm & (Corne et al., 2001) \\
\hline \hline
\end{tabular}

Tabela 2.1: Diferentes Modelos de AEMO.

por torneio, cruzamento e mutação obtém-se a população de indivíduos filhos $Q_{0}$. Tanto $P$ como $Q$ são de tamanho $N$.

No próximo passo ambas as populações são unidades em uma população $R_{0}=$ $P 0 \bigcup Q_{0}$, com $\left|R_{t}\right|=2 N$. Para as gerações seguintes, $t=1,2, \ldots$, , o algoritmo NSGA-II trabalha com a população $R_{t}$.

Obtida a população $R_{t}$ realiza-se a ordenação por não-dominância, obtendo as fronteiras $F_{1}, F_{2}, \ldots$ e todos esses conjuntos são inseridos na nova população $P_{t+1}$. Dado que apenas $N$ soluções podem ser inseridas na população $P_{t+1}, N$ soluções de $R_{t}$ são descartadas. Para preencher as populações $P_{t+1}$ começa-se com as soluções em $F_{1}$, se não forem completadas as $N$ soluções, prossegue-se com $F_{2}$ e assim por diante. Cada conjunto $F_{i}$ deve ser inserido na sua totalidade em $P_{t+1}$, isto ocorre quando $\left|P_{t+1}\right|+\left|F_{i}\right| \leq N$. Quando ocorre o caso de ao inserir $F_{j},\left|F_{j}\right|>N-\left|P_{t+1}\right|$, o algoritmo NSGA-II seleciona as soluções de $F_{j}$ que estejam melhor diversificadas. A Figura 2.1 ilustra uma iteração do algoritmo NSGA-II. O algoritmo NSGA-II introduz um método chamado de distância de multidão (crowding distance). Uma vez obtidas as distâncias, os conjuntos de soluções $F_{j}$ são ordenados decrescentemente em relação às suas distâncias, e copia-se as primeiras $N-\left|P_{t+1}\right|$ soluções de $F_{j}$ para $P_{t+1}$. Finalmente, obtém-se $Q_{t+1}$ a partir de $P_{t+1}$ usando os operadores de seleção por torneio, crossover e mutação. 


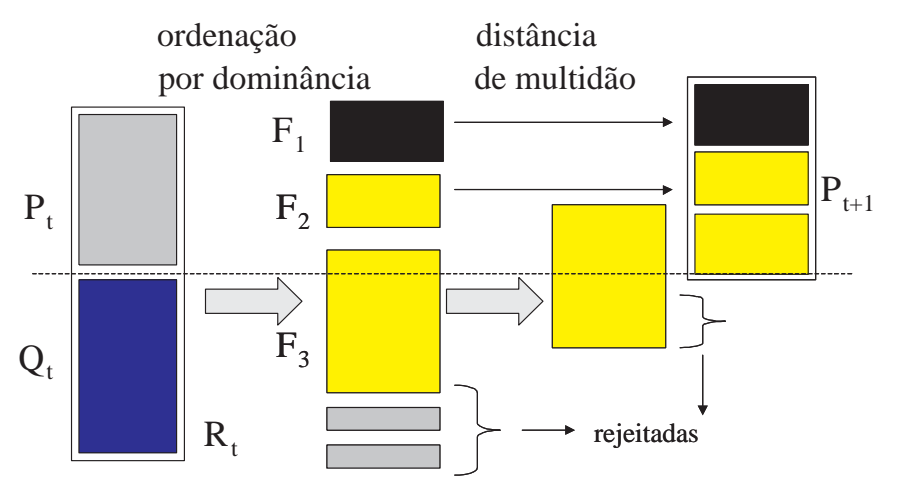

Figura 2.1: Esquema do Modelo NSGA-II (Deb, 2001).

\subsubsection{Distância de Multidão}

A distância de multidão de uma solução $i, d_{i}$, representa uma estimativa do perímetro formado pelo cubóide cujos vértices são os seus vizinhos. A Figura 2.2 apresenta a distância de multidão para a solução $i$. Quanto maior o cubóide de $i$, mais afastada se encontra a solução $i$ dos seus vizinhos. As soluções extremas em cada objetivo, ou seja a melhor e a pior solução em cada objetivo, terão um cubóide infinito. O procedimento para encontrar a distância de multidão está descrito no Algoritmo 2.2, onde $I_{i}^{m}$ representa a $i$-ésima solução na lista ordenada pelo objetivo $m . I_{1}^{m}$ e $I_{l}^{m}$ são os elementos da lista com o menor e o maior valor para um objetivo $m$. $f_{m}^{I_{i+1}^{m}}$ e $f_{m}^{I_{i-1}^{m}}$ são os valores dos vizinhos de $i$ na $m$-ésima função objetivo. $f_{m}^{\max }$ e $f_{m}^{\text {min }}$ são parâmetros dos limites máximo e mínimo em cada objetivo. A Equação 2.1 garante que as soluções mais afastadas tenham $d_{i}$ maior do que as mais próximas.

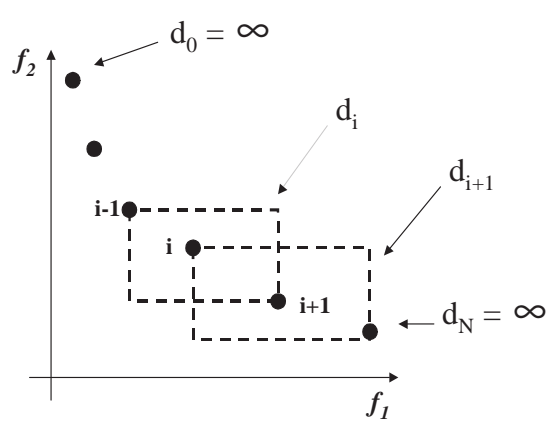

Figura 2.2: Cálculo da distância de multidão no NSGA-II (Deb, 2001).

A principal vantagem do NSGA-II é a forma como é mantida a diversidade entre as soluções não-dominadas. O método de comparação por multidão é utilizado para a seleção por torneio e para escolher os elementos da fronteira $F_{j}$ (Deb, 2001). 


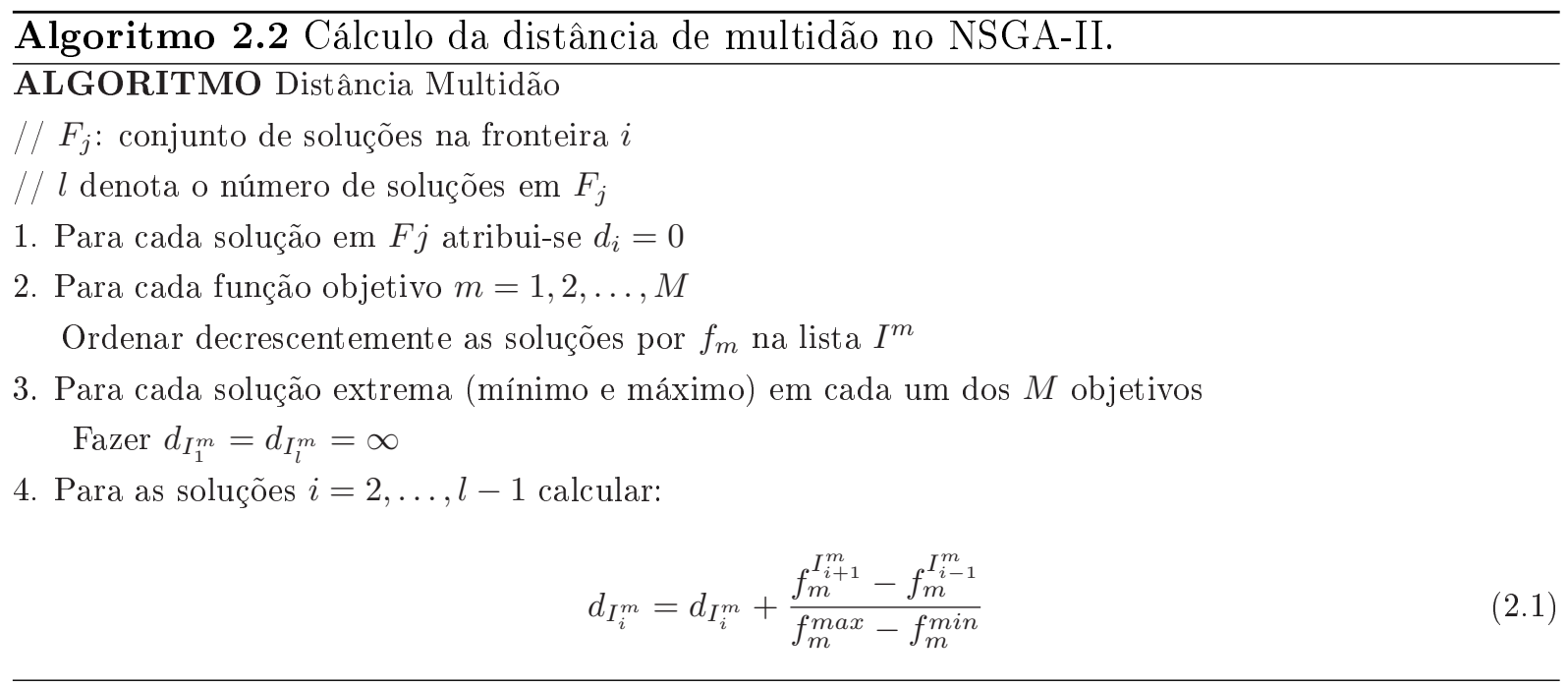

Se o conjunto $F_{1}$ tem um tamanho maior que $N$, o processo de escolher apenas $N$ soluções utilizando a distância de multidão faz com que sejam perdidas soluções. Seja um conjunto $F_{1}$ onde existam várias soluções Pareto-ótimas muito próximas e alguma solução distante não Pareto-ótima, mas não-dominada no momento. Dado que o cuboide da solução não-dominada é maior, esta solução será copiada em $P_{t+1}$ enquanto que uma solução Pareto-ótima é eliminada. Esta situação faz com que o NSGA-II possa cair em um ciclo de gerar soluções Pareto-ótimas e não-Pareto-ótimas até convergir finalmente a um conjunto de soluções Pareto-ótimas (Deb, 2001).

\subsection{Considerações Finais}

Neste Capítulo foi introduzida a CE como um novo paradigma da Ciência da Computação que abrange um conjunto de algoritmos que tem por base simular ou reproduzir no computador princípios encontrados nos sistemas naturais para se desenvolver.

Resumidamente, CE engloba um conjunto de algoritmos inspirados na Teoria Evolutiva do Neodarwinismo. Os primeiros artigos e teses demonstraram a capacidade que os AEs possuem (Fogel et al., 1966; Rechenberg, 1973; Holland, 1975; Jong, 1975; Schwefel, 1975), apesar das limitações de hardware existentes na época. Assim como outras tentativas de propor novos métodos no meio acadêmico, os AEs também tiveram de enfrentar um período de rejeição. Somente na década de 1990, com os resultados relevantes obtidos, o poder dos AEs na solução de problemas complexos foi verificado. A partir de então, vários trabalhos têm sido propostos utilizando AEs (Bäck, 1996; Davis, 1991; Fogel, 1994; Holland, 1992; Kinnear, 1994; Koza, 1992; Michalewicz, 1996). 
Os principais algoritmos encontrados na computação evolutiva, genericamente denominados como AEs, são: programação evolutiva, estratégias evolutivas, algoritmos genéticos, sistemas classificadores e programação genética, sendo o mais utilizado e conhecido desses o AG. 


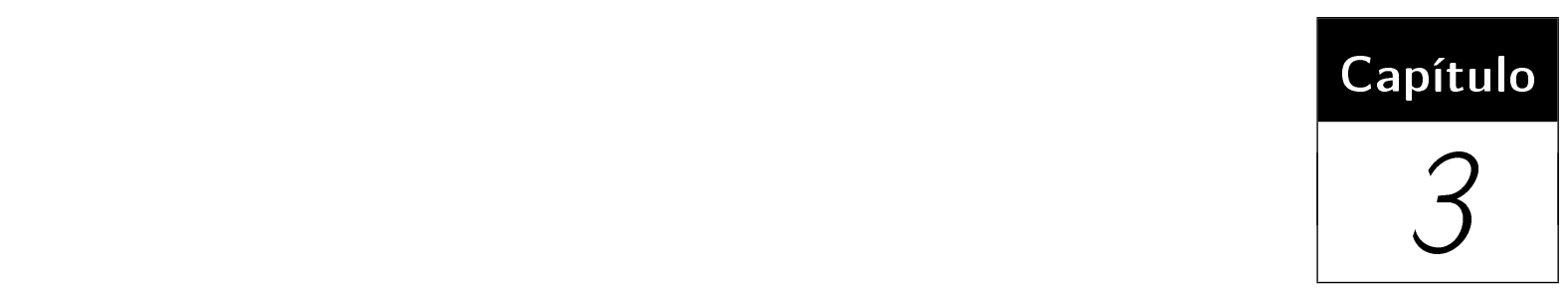

\section{Introdução à Estrutura de Proteínas}

$\mathcal{P}$

roteínas são biopolímeros que possuem como alfabeto um conjunto de 20 aminoácidos. As proteínas são responsáveis por várias funções nos organismos vivos, dentre elas, ações de catálise ${ }^{1}$. Um dos mais conhecidos e importantes tipos de proteínas são as enzimas, que exercem um papel muito importante nos organismos vivos (Branden and Tooze, 1991).

Uma importante propriedade das proteínas é a classificação de suas estruturas hierarquicamente:

- estrutura primária: seqüência linear dos diferentes aminoácidos que compõem a proteína, a qual é diretamente determinada pela sequência de nucleotídeos na codificação gênica;

- estrutura secundária: segmentos dobrados de uma cadeia polipeptídica com repetições de ângulos de torção da cadeia principal ( $\phi$ e $\psi)$ característicos, que são estabilizados por um padrão regular de pontes de hidrogênio entre os grupos peptídicos $-N-H$ e $C=O$ de diferentes resíduos (Petsko and Ringe, 2004);

- estrutura terciária: organização tridimensional de elementos de estrutura secundária em coordenadas atômicas, estabilizados por um grande número de interações fracas;

\footnotetext{
${ }^{1}$ Catalise é o fenômeno que causa uma reação química ou a acelera pela adição de uma substância, que aparece inalterada quimicamente ao final da reação.
} 
- estrutura quaternária, união de cadeia polipeptídicas formando um conjunto único (Copeland, 1993).

As proteínas podem ser classificadas, em sua maioria, em três tipos de estrutura tridimensional, que são domínios $\alpha, \beta$ e $\alpha / \beta$, os quais são apresentados na Seção 3.5 sobre estrutura terciária. Estas podem ser determinadas por meio de dois métodos experimentais de cristalografia de raio-X e ressonância nuclear magnética (RNM). Algumas proteínas não podem ter sua estrutura determinada pelos métodos experimentais, por não poderem ser cristalizadas, no caso da cristalografia de raio-X, ou por serem grandes, não podendo ser tratadas pelo método de RNM (ver Seção 3.6). Nesses casos, são necessários outros meios para obter a estrutura terciária da proteína.

As proteínas exercem diversas funções bioquímicas sendo as principais atuações: ligação, catálise, atuando como chave molecular e servindo como componente estrutural de células e organismos. Proteínas podem ligar-se a outras macromoléculas, tais como DNA ou outras proteínas. Esta função explica a habilidade das proteínas em apresentar superfícies estruturalmente e quimicamente diversas que podem interagir com outras moléculas com alta especificidade (Petsko and Ringe, 2004). A estrutura terciária da proteína é responsável por determinar a função da proteína no organismo. A partir da estrutura terciária é possível a obtenção de compostos químicos que se liguem ao sítio ativo ${ }^{2}$ da proteína e, por exemplo, impeçam a sua ação no organismo.

Neste capítulo são apresentadas as proteínas, seus elementos, seu processo de formação e a determinação da estrutura terciária. A Seção seguinte discute os aminoácidos e suas características. A Seção 3.2 apresenta as ligações peptídicas e suas propriedades. A Seção 3.3 apresenta uma forma de classificação das proteínas com base na sua conformação. A Seção 3.4 mostra a estrutura secundária e seus principais motivos. A Seção 3.5 introduz a estrutura terciária e seus domínios, por fim, a Seção 3.6 apresenta os métodos para a determinação da estrutura terciária da proteína.

\subsection{Aminoácidos}

Aminoácidos são compostos orgânicos que possuem uma estrutura básica comum, apresentada na Figura 3.1, que consiste de um carbono central denominado carbono $\alpha$, o qual possui quatro ligantes diferentes, um grupo carboxila $(\mathrm{COOH})$, um grupo amino $\left(\mathrm{NH}_{2}\right)$ e um radical $\mathrm{R}$ também chamado cadeia lateral do aminoácido (que pode con-

\footnotetext{
${ }^{2}$ Sítio ativo é o local onde o substrato, no caso das enzimas, ou receptor, no caso das demais proteínas, encaixa-se.
} 
sistir desde um único átomo de hidrogênio até complexos anéis aromáticos) (Copeland, 1993). As proteínas são formadas a partir de um conjunto de vinte aminoácidos que se diferenciam pelas suas cadeias laterais. Quando presentes em proteínas, os aminoácidos são denominados de resíduos, pois no processo de formação da proteína ocorre a perda de átomos (geralmente uma molécula de água - $\mathrm{H}_{2} \mathrm{O}$ ) que compunham a estrutura completa do aminoácido.

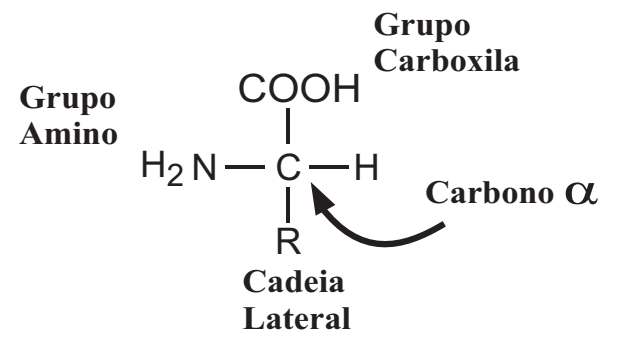

Figura 3.1: Estrutura geral de um aminoácido.

Um código de três ou uma letra é utilizado como mnemônico para representar os aminoácidos. O peso molecular dos aminoácidos varia no intervalo de 57 daltons (ver glossário) (glicina) a 186 daltons (triptofano) com peso molecular médio de 110 daltons . Assim, uma proteína com peso molecular 33.000 daltons é composta por aproximadamente 300 aminoácidos (Schulz and Schirmer, 1979). Os vinte aminoácidos estão apresentados na Tabela 3.1, com seus respectivos códigos de três e uma letra e peso molecular. A Figura 3.1 apresenta a estrutura química dos vinte aminoácidos presentes nas proteínas.

Dependendo da natureza química da cadeia lateral, os aminoácidos podem ser divididos em três diferentes classes. A primeira classe compreende os aminoácidos com cadeia lateral estritamente hidrofóbica, isto é o composto da cadeia lateral não se dissolve em contato com a água (Alanina, Valina, Leucina, Isoleucina, Fenilalanina e Prolina). Aminoácidos que possuem cadeia lateral estritamente hidrofílica, isto é o composto da cadeia lateral se dissolve em contato com a água, compõem a segunda classe (Ácido Aspártico, Ácido Glutâmico, Serina, Treonina, Cisteína, Asparagina, Glutamina, Histidina e Argenina). A terceira classe é composta pelos aminoácidos com características polares e apolares, também chamados anfipáticos (Lisina, Tirosina, Metionina, e Triptofano) (Petsko and Ringe, 2004). Na segunda e terceira classe os compostos da cadeia lateral dissolvem-se na presença da água.

Os aminoácidos com cadeia lateral hidrofóbica são empregados somente em interações de van der Waals (ver glossário). Sua tendência em evitar contato com a água e agruparem-se uns com os outros é a base para o efeito hidrofóbico.

Resíduos com cadeia lateral hidrofílica são capazes de formar pontes de hidrogênio 


\begin{tabular}{||c|c|c|c|c||}
\hline \hline Aminoácido & Cód. 3 letras & Cód. 1 letra & $\begin{array}{c}\text { Origem do } \\
\text { Cod. 1 Letra }\end{array}$ & Peso Molecular \\
\hline \hline Alanina & Ala & A & Alanine & 71 \\
\hline Cisteína & Cys & C & Cysteine & 103 \\
\hline Ácido Aspártico & Asp & D & asparDic acid & 114 \\
\hline Fenilalanina & Phe & F & Fenylalanine & 147 \\
\hline Ácido Glutâmico & Glu & E & gluEtamic acid & 128 \\
\hline Glicina & Gly & G & Glycine & 57 \\
\hline Histidina & His & H & Histidine & 137 \\
\hline Isoleucina & Ile & I & Isoleucine & 113 \\
\hline Lisina & Lys & K & letra antes do $L$ & 129 \\
\hline Leucina & Leu & L & Leucine & 113 \\
\hline Metionina & Met & M & $M$ ethionine & 131 \\
\hline Asparagina & Asn & N & asparagi $N e$ & 114 \\
\hline Prolina & Pro & P & Proline & 97 \\
\hline Glutamina & Gln & Q & $Q$-tamine & 128 \\
\hline Arginina & Arg & R & aRginine & 157 \\
\hline Serina & Ser & S & $S$ erine & 87 \\
\hline Treonina & Thr & T & Theorine & 101 \\
\hline Valina & Val & V & $V$ aline & 99 \\
\hline Triptofano & Trp & W & t $W$ o rings & 186 \\
\hline Tirosina & Tyr & Y & t $Y$ rosine & 163 \\
\hline & & & & \\
\hline
\end{tabular}

Tabela 3.1: Relação dos vinte aminoácidos padrões e respectivos mnemônicos.

com outro resíduo, com a cadeia peptídica principal, com moléculas orgânicas polares, e com a água. Esta tendência domina as interações nas quais estes resíduos podem participar. Alguns destes resíduos podem mudar seu estado de carga dependendo do $p H$ ou do microambiente.

Resíduos anfipáticos possuem ambas as características polares e apolares, ou seja parte da cadeia lateral possui características hidrofóbicas e parte características hidrofílicas, fazendo-os então ideais para formar interfaces. Pode parecer surpreendente considerar a cadeia lateral polar da lisina como anfipático, mas sua longa região hidrofóbica está freqüentemente envolvida em interações de van der Waals com cadeias laterais hidrofóbicas. Tirosina não está geralmente ionizada em $p H$ fisiológico, mas em algum sítios ativos de enzimas, ela pode participar em reações ácido-base porque o ambiente pode abaixar seu $p K_{a}$.

O aminoácido glicina tem somente um átomo de hidrogênio como cadeia lateral sendo, portanto, o mais simples dos vinte aminoácidos. Este aminoácido possui algumas propriedades especiais, sendo geralmente considerado como de uma quarta classe (Branden and 
Aminoácidos com cadeia lateral hidrofóbica<smiles>CC(C)C([NH3+])C(=O)[O-]</smiles>

Valina

(val)<smiles>CC(C)CC([NH3+])C(=O)[O-]</smiles>

Leucina

(leu)<smiles>CCC(C)C([NH3+])C(=O)[O-]</smiles>

Isoleucina

(ile)<smiles>CSCCC([NH3+])C(=O)[O-]</smiles>

Metionina (met)<smiles>NC(Cc1ccccc1)C(=O)O</smiles>

Fenilalanina (phe)

Aminoácidos com cadeia lateral hidrofílica<smiles>NC(=O)CC(N)C(=O)O</smiles>

Asparagina (asn)<smiles>[NH3+]C(CC(=O)[O-])C(=O)[O-]</smiles>

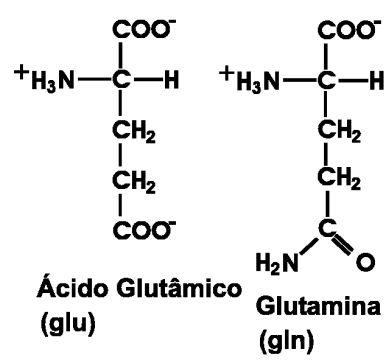

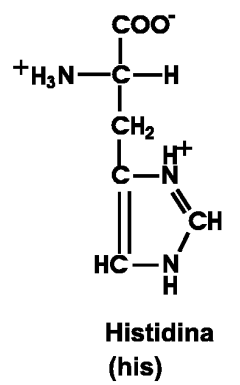

(his)

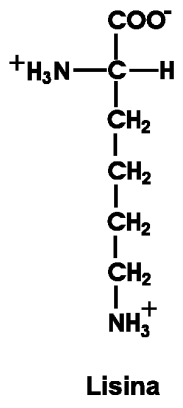

(lys)

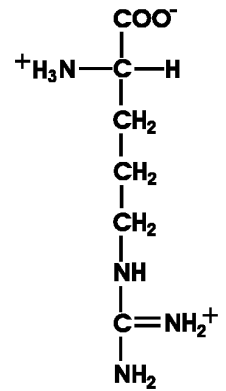

Argenina (arg)

\section{Ácido Aspártico}

(asp)

Aminoácidos que estão entre os dois<smiles>CC(NCCCC(=O)[O-])C(=O)[O-]</smiles><smiles>[NH3+]C(CO)C(=O)[O-]</smiles>

Serina (ser)<smiles>O=C([O-])C1CCCN1</smiles>

Prolina

(pro)<smiles>CC(O)C(N)C(=O)[O-]</smiles>
Treonina (thr)<smiles>[NH3+]C(CS)C(=O)[O-]</smiles>

(cys)<smiles>CC(N)(Cc1ccc(O)cc1)C(=O)O</smiles>

Tirosina

(tyr)<smiles>N[C@@H](Cc1c[nH]c2ccccc12)C(=O)[O-]</smiles>

Triptofano

(trp)

Figura 3.2: Classificação dos vinte aminoácidos padrões encontrados em proteínas.

Tooze, 1991).

Os compostos orgânicos podem assumir teoricamente dois tipos de configuração, em relação ao carbono $\alpha$, que são denominadas tipo L ou trans e tipo $\mathrm{R}$ ou cis, a diferença entre as duas configurações é a posição dos grupos amino e carboxila. Os aminoácidos presentes 
na formação de proteínas biológicas são sempre do tipo L, até o momento não se encontrou nenhuma justificativa química ou evolutiva para essa escolha específica (Branden and Tooze, 1991).

Dois aminoácidos de cisteína em partes diferentes de uma cadeia polipeptídica (ver Seção 3.2) e não adjacentes em uma estrutura tridimensional, podem formar pontes de dissulfeto por oxidação. Essas pontes de dissulfeto ocorrem mais freqüentemente em proteínas extracelulares, ou seja, que são secretadas pela célula. Essas pontes garantem a estabilidade da estrutura tridimensional da proteína (Branden and Tooze, 1991).

\subsection{Ligações Peptídicas e os Polipeptídeos}

Polímeros são macromoléculas constituídas por unidades químicas repetidas, chamadas "meros", unidas, normalmente em linha. Cada "mero" constitui-se de mais de cinco átomos e menos de 500 átomos, a palavra polímero é aplicada quando se têm mais de 50 "meros" unidos. A ligação química que conduz a formação de polímeros é a polimerização. Proteínas são considerados polímeros pois são macromoléculas com unidades químicas repetidas.

Os aminoácidos formam polímeros (cadeias polipeptídicas) por meio de ligações covalentes denominadas ligações peptídicas, este processo de polimerização ocorre no ribossomo da célula (Schulz and Schirmer, 1979). Essas ligações ocorrem entre o grupo carboxila de um aminoácido e o grupo amino do outro (Copeland, 1993). Durante o processo de ligação ocorre a perda de uma molécula de água, a Figura 3.3 representa o resultado de uma ligação peptídica. Embora a formação da ligação peptídica possa ser revertida pela adição de água (hidrólise), ligações peptídicas são muito estáveis na água em pH neutro, além disso a hidrólise de ligações peptídicas nas células é também controlada enzimaticamente (Petsko and Ringe, 2004).

Quando vários aminoácidos estão conectados, o polímero resultante é denominado polipeptídeo. É importante ressaltar que a diferença entre proteínas e polipeptídeos é basicamente semântica, por definição todas as proteínas são polipeptídeos, porém costuma-se chamar de polipeptídeo apenas pequenas sequências de aminoácidos. As proteínas e os polipeptídeos podem ser unicamente identificados pela sequência em que seus aminoácidos estão ligados e a essa sequência denomina-se estrutura primária da proteína. A direção da cadeia polipeptídica é determinada a partir do amino terminal ( $\mathrm{N}$ terminal) até o grupo carboxila terminal (C terminal) (Schulz and Schirmer, 1979). 

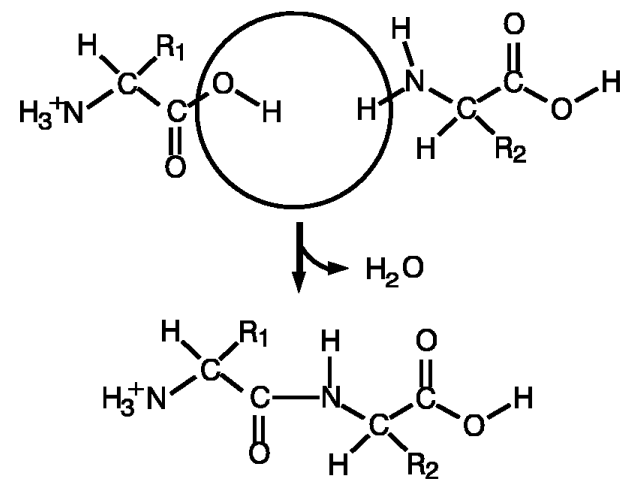

+aminoácido 3
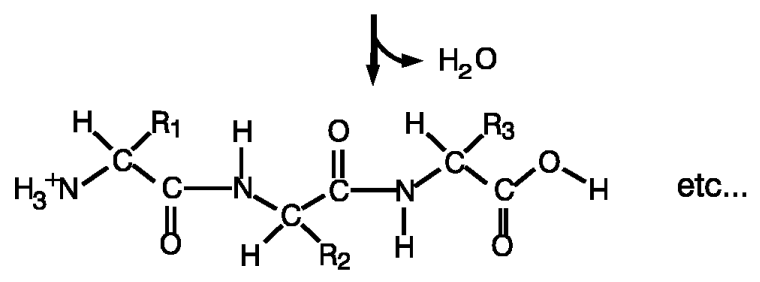

Figura 3.3: Processo de formação de uma ligação peptídica.

\subsubsection{Propriedades das Ligações Peptídicas}

As características das ligações peptídicas contribuem para algumas propriedades importantes das cadeias polipeptídicas na água. A estabilidade da ligação peptídica, bem como outras propriedades importantes para o comportamento de polipeptídeos originamse da ressonância e da movimentação de elétrons sobre vários átomos. Uma consequência da ressonância é o aumento da polaridade da ligação peptídica. A polaridade da ligação peptídica pode fazer uma importante contribuição para o comportamento das proteínas dobradas, garantindo a estabilidade da formação das interações como pontes de hidrogênio na formação de hélices, por exemplo (Petsko and Ringe, 2004).

A primeira propriedade observada é que o comprimento da ligação peptídica não poder ser medido como uma dupla ligacão carboxílica $(\mathrm{C}=\mathrm{O})$ típica e uma ligação simples carbono-nitrogênio. Ao contrário disso, ambas as distâncias das ligações carboxi e carbono-nitrogênio estão nos valores intermediários entre as distâncias conhecidas para compostos deste tipo. A explicação para esses valores resulta da nuvem de elétrons observada na molécula triatômica $\mathrm{O}-\mathrm{C}-\mathrm{N}$, na qual a dupla ligação fica alternando-se desta forma $\mathrm{O}=\mathrm{C}-\mathrm{N}$ e $\mathrm{O}-\mathrm{C}=\mathrm{N}$ (Copeland, 1993). Observa-se que estas ligações ocorrem em uma estrutura planar, assim os seguintes seis átomos fazem parte de um mesmo plano (ver Figura 3.4): $C_{i}^{\alpha}, C_{i}, O_{i}, N_{i+1}, H_{i+1}, C_{i+1}^{\alpha}$, ou seja, carbonos $\alpha$ de aminoácidos adjacentes estão no mesmo plano (Schulz and Schirmer, 1979). 


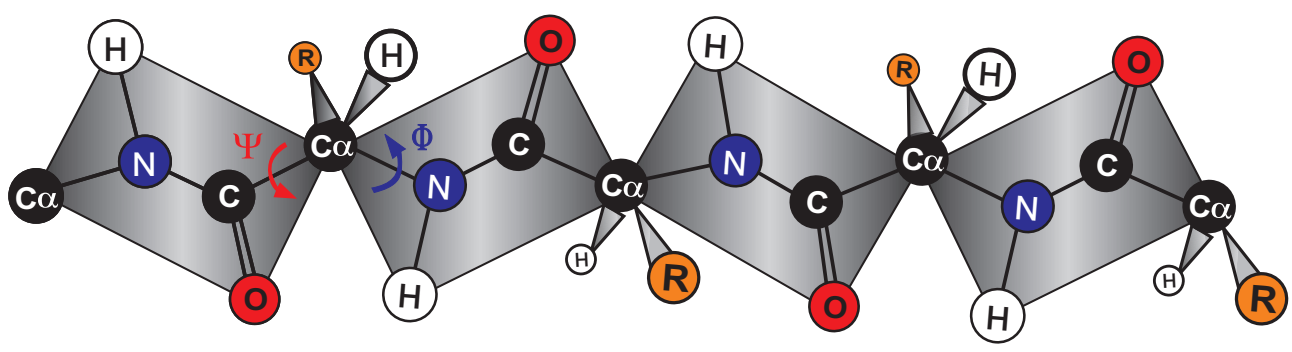

Figura 3.4: Representação dos átomos no mesmo plano.

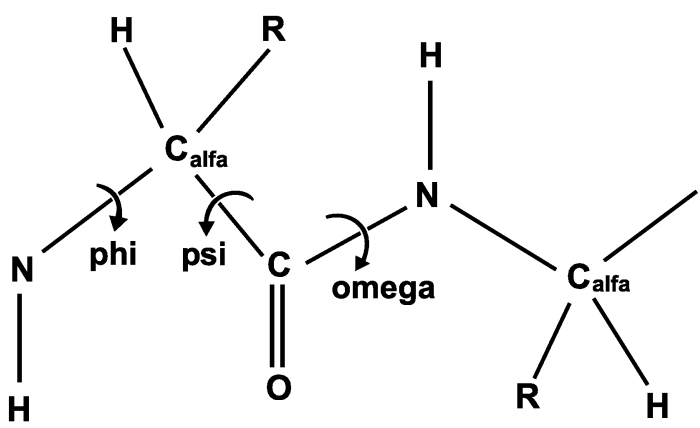

Figura 3.5: Ângulos $\psi$ e $\phi$.

Outra propriedade observada é que, embora a rotação sobre a ligação C-N seja restrita (onde $\mathrm{C}$ não é o carbono $\alpha$ ) rotações sobre o $\mathrm{C}_{\alpha}-\mathrm{N} \mathrm{e}_{\alpha}-\mathrm{C}$ podem ocorrer livremente, estas rotações livres podem ser descritas por dois ângulos $\phi$ e $\psi$, associados respectivamente a cada uma das ligações (ver Figura 3.5). Analisando diversos cristais de proteínas, Ramachandran e seus colaboradores observaram que os ângulos $\phi$ e $\psi$ concentravam-se em determinadas faixas de valores. Com base nesses estudos foi construído o mapa de Ramachandran (ver Figura 3.6 (Ramachandran and Sasiskharan, 1968)).

Os pares $\phi$ e $\psi$ concentram-se em duas regiões do mapa para todos os aminoácidos exceto a glicina que, por apresentar uma cadeia lateral muito simples, possui menos restrições espaciais conformacionais. Pode-se observar também que cada um dos dois quadrantes de concentração pode ser associado a um tipo de estrutura secundária, a qual será discutida na Seção 3.4 (Copeland, 1993). Os ângulos $\phi$ e $\psi$ são chamados de ângulos diedrais e são responsáveis por definir a forma da cadeia principal do polipeptídeo, o ângulo $\omega$, considerando o tipo do aminoácido L ou D, pode assumir os valores de $180^{\circ}$ graus ou $0^{\circ}$ graus. Os valores assumidos pelo ângulos diedrais respeitam a propriedade de que os carbonos $\alpha$ de dois aminoácidos adjacentes devem estar no mesmo plano. 


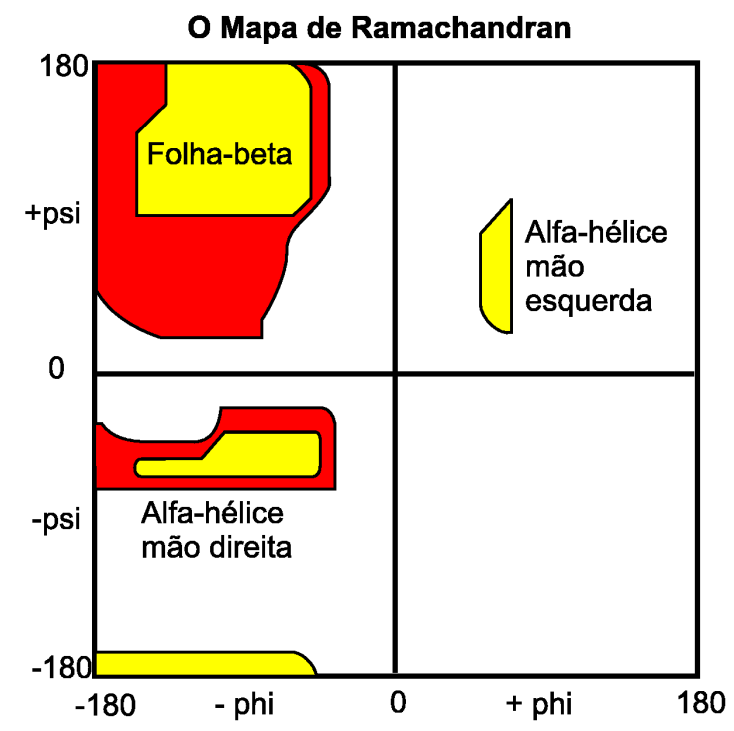

Figura 3.6: Mapa de Ramachandran.

\subsection{A Conformação das Proteínas}

Cada tipo de molécula protéica tem, em seu estado nativo, uma configuração tridimensional peculiar, designada conformação. Dependendo de sua conformação, as proteínas podem ser classificadas como fibrosas ou globulares (Lehninger, 1976):

- Proteínas fibrosas são materiais insolúveis em água e soluções salinas diluídas e fisicamente resistentes. São constituídas de cadeias polipeptídicas dispostas paralelamente ao longo de um único eixo. Os exemplos são: o colágeno dos tendões e da matriz óssea, a queratina dos cabelos e a elastina do tecido conjuntivo elástico. Algumas proteínas fibrosas, porém, possuem uma estrutura diferente, como as tubulinas, que são formadas por múltiplas subunidades globulares dispostas helicoidalmente;

- Proteínas globulares de estrutura espacial mais complexa, são formadas de cadeias polipeptídicas que se dobram, adquirindo formas esféricas ou globulares. A maioria dessas proteínas é solúvel em sistemas aquosos. Nesta categoria situam-se as proteínas ativas como os enzimas, transportadoras como a hemoglobina, entre outras.

\subsection{Estrutura Secundária}

Embora proteínas sejam polímeros lineares, as estruturas da maioria das proteínas não são cordões aleatórios encontrados para polímeros sintéticos não naturais. A maioria das 
proteínas solúveis são globulares e tem um centro ligeiramente empacotado consistindo primariamente de aminoácidos hidrofóbicos. Esta observação pode ser explicada pela tendência que grupos hidrofóbicos possuem de evitar contato com a água e de interagir com outros resíduos. Outra característica interessante de cadeias polipeptídicas dobradas é que os segmentos da cadeia em aproximadamente todas as proteínas adotam conformações nas quais os ângulos de torção $\phi$ e $\psi$ da cadeia principal repetem-se em padrões regulares. Esses padrões regulares formam os elementos da estrutura secundária da proteína. Dois tipos gerais de elementos de estrutura secundária tem sido definidos: hélice, dos quais a mais comum são as $\alpha$ hélices; folhas $\beta$, as quais tem duas formas paralela e antiparalela. Voltas $\beta$, são considerados elementos de estrutura secundária, apesar de não apresentarem padrões regulares dos ângulos de torção. Nas voltas $\beta$ a cadeia é forçada na direção contrária (ver Figura 3.7), ou seja inverte o sentido da cadeia, e que faz a dobra compacta da cadeia polipeptídica possível (Petsko and Ringe, 2004).

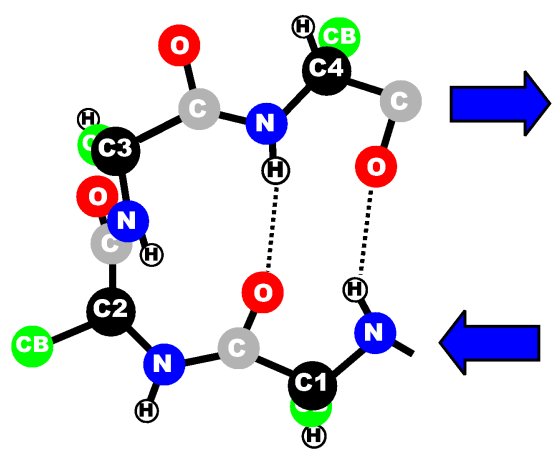

Figura 3.7: Esquema de uma Volta $\beta$.

Estes tipos de estrutura secundária são considerados estáveis estruturalmente, devido principalmente à formação de pontes de hidrogênio entre os grupos carboxila e amino de aminoácidos não diretamente ligados e que devido a estrutura tridimensional da proteína, encontram-se próximos (Copeland, 1993). A estrutura secundária contribui significativamente para a estabilização da dobra total da proteína. As pontes de hidrogênio desses elementos de estrutura provêm muito da entalpia de estabilização que permite que os grupos polares da cadeia principal existirem no centro hidrofóbico da proteína dobrada (Petsko and Ringe, 2004).

\subsubsection{Volta $\beta$}

O mais simples elemento de estrutura secundária é a volta $\beta$ que geralmente envolve quatro resíduos mas algumas vezes requer somente 3 resíduos. Consiste de pontes de 
hidrogênio entre o oxigênio do grupo carbonila de um resíduo $(i)$ e o grupo amino $N-H$ do resíduo $i+3$, revertendo a direção da cadeia (ver Figura 3.7). Este padrão de pontes de hidrogênio não pode ordináriamente continuar porque a volta é fraca. Em alguns casos esta interação pode ocorrer entre os resíduos $i$ e $i+2$.

Embora a volta $\beta$ represente um simples caminho para satisfazer a capacidade de pontes de hidrogênio de um grupo peptídico, a inspeção desta estrutura revela que a maioria dos grupos $C=O$ e $N-H$ nos quatro resíduos que compoem a volta não formam pontes de hidrogênio com outros átomos da cadeia principal. Moléculas de água podem doar e aceitar pontes de hidrogênio desses grupos se a volta não é escondida. Por isso, voltas $\beta$ são encontradas nas superfícies de proteínas dobradas, onde elas estão em contato com o ambiente aquoso e, pela reversão da direção da cadeia, podem limitar o tamanho da molécula e manter um estado compacto (Petsko and Ringe, 2004).

\subsection{2 $\alpha$-Hélice}

As estruturas $\alpha$ são o elemento de estrutura mais comum em uma cadeia polipeptídica dobrada, possivelmente porque são geradas por pontes de hidrogênio locais entre os grupos $C=O$ e $N-H$ próximos na sequência. Este formato deve-se à repetição de valores dos ângulos $\phi$ e $\psi$ nos aminoácidos que estão presentes na $\alpha$ hélice, assumindo valores próximos a -60 e -50 graus para os ângulos $\phi$ e $\psi$ respectivamente. As $\alpha$ hélices possuem 3,6 aminoácidos por volta com pontes de hidrogênio entre $\mathrm{C}=\mathrm{O}$ do aminoácido $i$ e $\mathrm{NH}$ do aminoácido $i+4$ (ver Figura 3.8). Todos os pares $\mathrm{CO}$ e $\mathrm{NH}$ estão interligados por pontes de hidrogênio exceto grupo NH (amino terminal) da primeira volta e o grupo CO (carboxi terminal) da última volta da $\alpha$-hélice. As c adeia laterais salientes determinam as interações da $\alpha$-hélice com outras partes da cadeia proteíca dobrada e com outras moléculas proteícas.

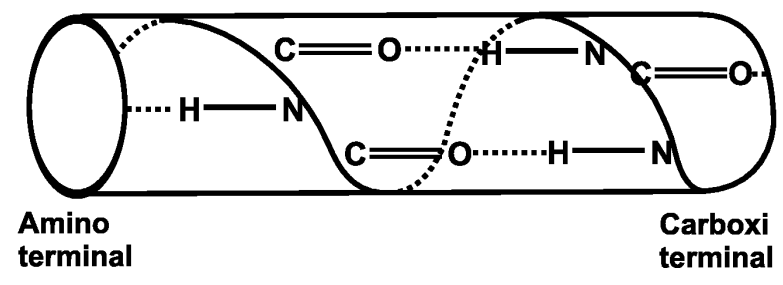

Figura 3.8: $\alpha$ hélice.

As $\alpha$-hélices possuem número variado de aminoácidos. Por exemplo, em proteínas globulares (ver Seção 3.3) existem tanto $\alpha$ hélices pequenas, com 4 ou 5 aminoácidos, quanto maiores, com mais de 40 aminoácidos. Em média seu comprimento é de 10 aminoácidos, 
correspondendo a três voltas. Cada resíduo na volta mede em média 1,5 $\AA$ de altura do cilindro em que a $\alpha$-hélice pode ser inserida, isto corresponde em média a $15 \AA$ de altura em uma hélice de tamanho médio, ou seja com 10 aminoácidos.

Hélices podem teoricamente ser de mão-direita ou de mão-esquerda dependendo da direção de enovelamento da cadeia. No entanto, como quase sempre encontram-se aminoácidos do tipo L nas proteínas, o tipo mais comum de hélice é a de mão-direita. Raramente encontram-se pequenas hélices de três ou cinco aminoácidos que são de mão-esquerda.

Existem alguns tipos de aminoácidos que possuem preferência por estarem em $\alpha$ hélices devido ao formato de sua cadeia lateral. Aminoácidos que formam hélices adequadamente são: alanina, ácido glutâmico, leucina e metionina. Por outro lado, prolina, glicina, tirosina e serina não se envolvem na formação dessas estruturas (Branden and Tooze, 1991).

\subsubsection{Folhas $\beta$}

O segundo maior grupo de estruturas secundárias são as folhas $\beta$. Estas estruturas são formadas pela combinação de várias regiões da cadeia do polipeptídeo. Tais regiões são chamadas de fitas $^{3}$ de folha $\beta$. As folhas $\beta$ possuem geralmente de 5 a 10 aminoácidos longos e com ângulos $\phi$ e $\psi$ maiores que 90 graus em módulo. As fitas de folhas $\beta$, que podem estar longe umas das outras na cadeia linear, são alinhadas lado a lado (ver Figura 3.9) com pontes de hidrogênio ligando o grupo CO de uma fita com o grupo NH de uma fita adjacente e vice-versa (Branden and Tooze, 1991).

Existem duas formas em que as fitas de uma folha $\beta$ podem interagir: a forma paralela e a antiparalela. Na paralela os aminos e carboxis terminais estão alinhados paralelamente (ver Figura 3.9). Na antiparalela, o carboxi terminal está alinhado com o amino terminal da fita de folha adjacente. Cada uma das formas, tem a seu modelo distinto de ponte de hidrogênio. No modelo antiparalelo as pontes de hidrogênio formam ângulos iguais a zero e têm todas o mesmo comprimento (ver Figura 3.9). No modelo paralelo as pontes de hidrogênio formam um pequeno ângulo, possuindo distâncias variadas (Branden and Tooze, 1991).

As fitas de folha $\beta$ podem combinar-se de diferentes formas, uma das formas é um misto de folhas paralelas com antiparalelas, onde um lado possui folhas paralelas e o outro folhas antiparalelas (ver Figura 3.9).

Folhas $\beta$ paralelas freqüentemente são escondidas e pequenas folhas $\beta$ paralelas quase

\footnotetext{
${ }^{3}$ A estrutura primária da proteína é graficamente representada no formato de uma fita (ver Figura 3.9 e 3.10 como exemplo).
} 


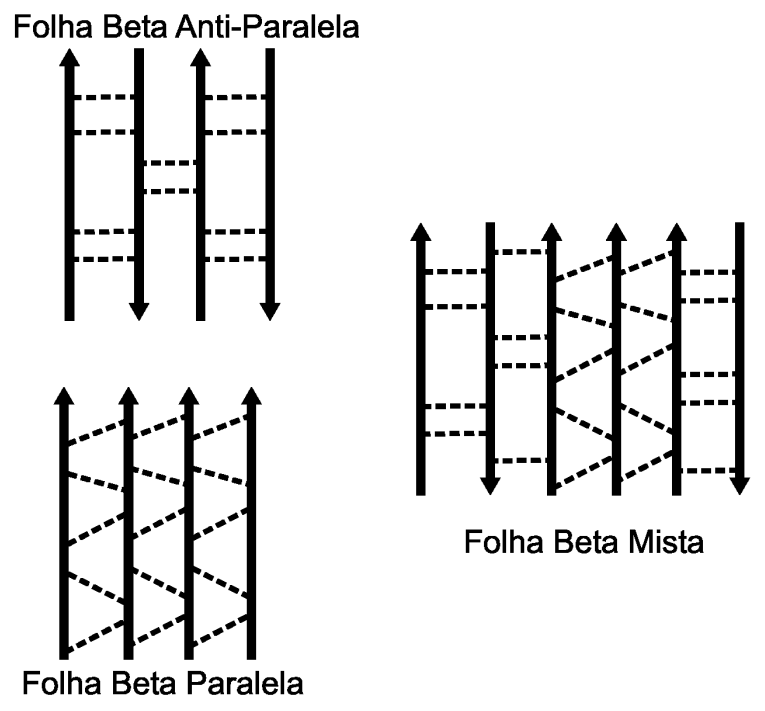

Figura 3.9: Folhas $\beta$.

nunca ocorrem. Folhas $\beta$ antiparalelas, por contraste, são freqüentemente expostas ao ambiente aquoso em uma face. Estas observações sugerem que folhas antiparalelas são mais estáveis, o que é consistente com suas pontes de hidrogênio mais lineares. Folhas antiparalelas normalmente possuem voltas $\beta$ conectando às fitas, embora algumas vezes as folhas possam vir de regiões descontínuas da sequência linear, neste caso as conecções são mais complexas e podem incluir segmentos de $\alpha$-hélice. Fitas de folhas paralelas são em geral descontínuas e a conexão mais comum entre elas é a $\alpha$-hélice que empacota contra a face da folha $\beta$ (Petsko and Ringe, 2004).

\subsection{Estrutura Terciária}

A estrutura terciária das proteínas representa o arranjo tridimensional assumido por sua cadeia polipeptídica devido à composição das cadeias laterais dos aminoácidos (ver Figura 3.10). Este nível na hierarquia das proteínas refere-se também a como os elementos da estrutura secundária estarão dispostos no espaço tridimensional e como os aminoácidos interagem uns com os outros para formar pontes de hidrogênio, pontes eletrostáticas, também chamadas de pontes salinas e interações hidrofóbico-hidrofóbico (Branden and Tooze, 1991).

Esta forma tridimensional assumida pela proteína é chamada de dobra nativa (ou enovelamento nativo) e deve-se principalmente a variação de fatores termodinâmicos. As proteínas em sua estrutura nativa estão no formato que lhes permite ter a mínima energia livre, favorável na solução em que se encontram. Alguns fatores termodinâmicos 


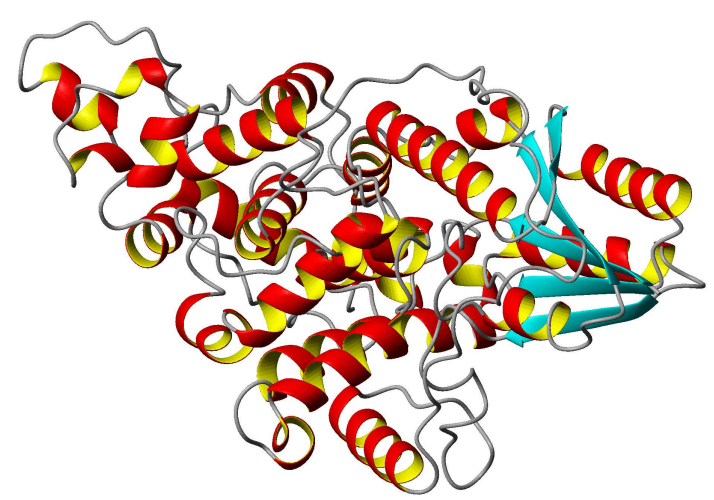

Figura 3.10: Estrutura terciária da proteína Crambin (PDB 1CRN).

influenciam o processo de dobramento das proteínas, sendo um dos mais importantes a necessidade de resguardar os aminoácidos não-polares do meio aquoso, o que forma o conhecido centro hidrofóbico da proteína. De forma similar, o processo de dobramento também procura favorecer as interações entre os aminoácidos polares e moléculas do solvente na superfícies hidrofílica da proteína. Assim, proteínas em seu estado natural sempre dobram-se espontaneamente em estruturas tridimensionais, quando em condições de soluções favoráveis (Copeland, 1993).

Porque a estrutura terciária não é regular, é dificil descrevê-la de maneira simples. Um caminho para caracterizar a estrutura terciária é por meio do arranjo topológico dos várias elementos da estrutura secundária. De fato, os mesmos tipos de elementos de estrutura secundária podem vir juntos em muitos diferentes caminhos dependendo da sequência. A estrutura terciária é algumas vezes classificada de acordo com os arranjos dos elementos de estrutura secundária na sequência linear e no espaço. Um efeito da estrutura terciária é criar um superfície topográfica complexa que permite a proteína interagir especificamente com pequenas moléculas que podem ligar-se em fendas, ou com outras macromoléculas, com as quais a proteína pode ter regiões de topologia complementar e carga. Esses locais reconhecidos são freqüentemente formados de extensões de aminoácidos unindo elementos de estrutura secundária (Petsko and Ringe, 2004).

A estrutura terciária é muito importante. É por meio dela que é definida a forma e a dimensão da proteína. A estrutura terciária também permite definir o conceito de proximidades espaciais entre aminoácidos que estão distantes na cadeia linear (estrutura primária) da proteína, mas que precisam estar próximos para formar locais de catálise de uma enzima, locais ativos (ou sítio ativo) para a ligação de um receptor, ou um local de recombinação para a ação de outra proteína (Copeland, 1993). Em resumo, a estrutura 
terciária é responsável pela determinação da função da proteína no organismo.

\subsubsection{Domínio de Proteínas}

A unidade fundamental da estrutura terciária das proteínas é o domínio. Domínio é uma região compacta de estrutura de proteínas, que é freqüentemente, mas não sempre, composta de uma cadeia polipeptídica contínua ou parte dela, e é capaz de dobrar-se em uma estrutura tridimensional estável podendo existir sozinho na solução aquosa (Petsko and Ringe, 2004). Domínios são também unidades de função: diferentes domínios estão associados a diferentes funções. Proteínas podem ter somente um domínio ou, até mesmo, doze domínios ou mais. A noção de que os domínios de grandes proteínas são independentemente estáveis tem sido verificada pela clonagem da sequência de DNA correspondente e expressando-as independentemente. Não somente geram muitos deles formas estáveis, mas freqüentemente retêm parte da função bioquímica da proteína da qual são derivados. Um bom exemplo é o repressor bacterial Lac, que é uma proteína tetramérica que liga-se fortemente a uma sequência de DNA específica (ver Figura 3.11). Um dos dois domínios no monâmero pode combinar-se sozinho com outra molécula para formar um dímero ${ }^{4} \mathrm{e}$ ligar-se ao DNA com uma afinidade próxima a da proteína intacta. A função do outro domínio é formar um tetrâmero pela formação de interações proteína-proteína; combinase sozinha para formar um tetrâmero ${ }^{5}$ mas não liga-se ao DNA (Petsko and Ringe, 2004).

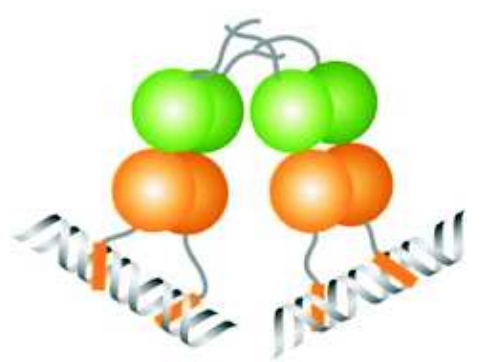

Figura 3.11: Repressor Lac tetrâmero ligado ao DNA (Petsko and Ringe, 2004).

Nem todos os domínios consistem de extensões contínuas de polipeptídeos. Em algumas proteínas, um domínio é interrompido por um bloco de sequência que dobra-se em um domínio separado, depois do qual o domínio original contínua. Por exemplo, a enzima

\footnotetext{
${ }^{4}$ Dímero é uma molécula formada por duas moléculas semelhantes.

${ }^{5}$ Tetrâmero é uma molécula formada por quatro moléculas semelhantes.
} 
alanina racemase possui um domínio interrompido deste tipo (ver Figura 3.12) (Petsko and Ringe, 2004).

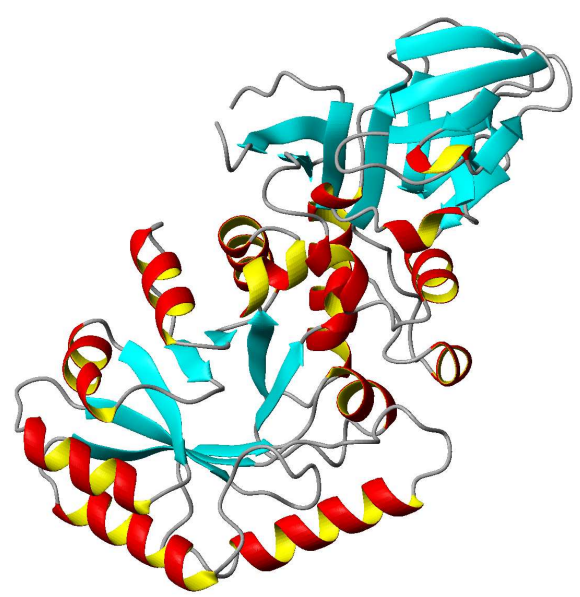

Figura 3.12: Estrutura da Alanina Racemase.

Domínios variam de tamanho mas geralmente não são maiores do que as maiores proteínas de domínio único, aproximadamente 250 aminoácidos, e a maioria possui em torno de 200 aminoácidos ou menos. Noventa e nove porcento de todos os domínios tem de 50 a 150 resíduos. O maior domínio de cadeia única tem 907 resíduos, e o maior número de domínios encontrado em uma proteína é 13 (Petsko and Ringe, 2004).

Centros hidrofóbicos parecem ser essenciais para a estabilidade dos domínios. Concentrar grupos hidrofóbicos no centro é energeticamente favorável pois essa configuração minimiza o número de interações de grupos hidrofóbicos com o meio aquoso e maximiza o número de interações de van der Waals dos grupos hidrofóbicos uns com os outros (Petsko and Ringe, 2004).

Os domínios são formados por diferentes combinações de elementos da estrutura secundária e motivos estruturais (ver glossário), que são padrões de disposição de elementos da estrutura secundária. Observa-se que motivos adjacentes na estrutura primária, também estão adjacentes na estrutura terciária. Uma mesma seqüência de motivos na estrutura primária pode resultar em diferentes combinações na estrutura terciária e determinar funções diferentes, além de ter diferentes sequências de aminoácidos. Motivos simples podem ser combinados para formar motivos complexos, estes são freqüentemente encontrados nas estruturas tridimensionais das proteínas (Branden and Tooze, 1991).

Por meio da análise dos motivos conectados, Michael Levitt e Cyrus Chothia (Levitt and Chothia, 1976) derivaram a taxonomia da estrutura da proteínas mostrando que 
as diferentes combinações dos motivos constituem o centro da maioria dos domínios de estrutura e também forma a base para a classificação das proteínas em três grupos principais: domínio $\alpha$, somente $\alpha$ hélices, domínio $\beta$, somente folhas $\beta$, e o domínio $\alpha / \beta$ (com combinações $\beta-\alpha-\beta$ ). Estas três classes principais de proteínas serão analisadas nas próximas Seções.

\subsubsection{Domínios $\alpha$}

Estruturas do domínio $\alpha$ consistem de um pacote de $\alpha$-hélices que são conectadas por regiões de loop, pequenas seqüências de aminoácidos entre os motivos de estrutura secundária que não possuem um formato padrão, na superfície do domínio (ver Figura 3.13(b)). As $\alpha$-hélices são pareadas umas contra as outras, formando um centro hidrofóbico na parte interna da hélice e um centro hidrofílico na superfície. Pacotes de $\alpha$-hélices podem assumir diferentes arranjos variados, dos quais os mais freqüêntemente encontrados são o pacote de quatro hélices e a dobra globin (Branden and Tooze, 1991).

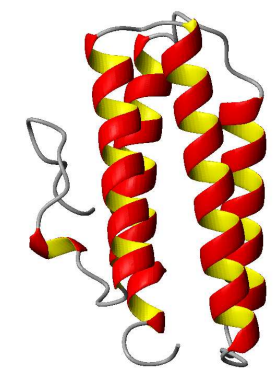

(a) Pacote de quatro hélices: Miohemoritrina (PDB 2MHR).

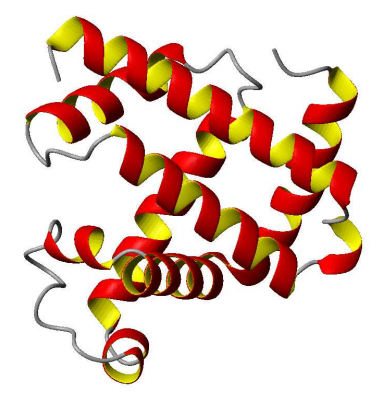

(b) Volta Globina: Mioglobina (PDB 1A6K).

Figura 3.13: Motivos Estruturais de Proteínas do Domínio $\alpha$.

O pacote de quatro hélices é formado por quatro hélices antiparelelas, cada uma cruzando a próxima em um ângulo de aproximadamente $-20^{\circ}$. Este pacote de quatro hélices tem sido encontrado em uma ampla variedade de domínios $\alpha$ serve para diversas funções como transporte de oxigênio, ligação com ácidos nucleícos, e transporte de elétrons. Exemplos de proteínas pacote de quatro hélices incluem Miohemoritrina (ver Figura 3.13(a)), uma proteína de armazenamento de oxigênio de vermes marinhos, e hormônios humanos de crescimento, que ajudam a promover o crescimento normal do corpo.

Outro motivo comum de domínio $\alpha$, a volta globina, consiste de uma "bolsa" de aproximadamente oito $\alpha$-hélices arranjadas em ângulos de $90^{\circ}$ e $50^{\circ}$ uma em relação a outra. Este motivo permite a formação de bolsões hidrofóbicos no domínio interior no qual grandes, 
organismos hidrofóbicos e grupos organimetálicos podem ligar-se (ver Figura 3.13(b)). Esta dobra recebe esse nome da proteína mioglobina, uma molécula de domínio único para armazenamento-oxigênio na qual oito hélices envolvem um grupo heme (Petsko and Ringe, 2004).

\subsubsection{Domínios $\alpha / \beta$}

O domínio de estruturas de proteína com maior representatividade é o domínio $\alpha / \beta$. Neste domínio a folha $\beta$ é composta de fitas paralelas e mistas. As fitas paralelas devem ser unidas por longas conexões uma vez que o segmento ligando-as deve atravessar o comprimento da folha e essas conexões são geralmente feitas por $\alpha$-hélices conectando fitas paralelas adjacentes, originando unidades beta-alfa-beta-alfa. Neste domínio, ligações de fenda são formadas pelas regiões de loop. Estas regiões não contribuem para a estabilidade estrutural mas, participam em ações de ligação e catálise (Branden and Tooze, 1991).

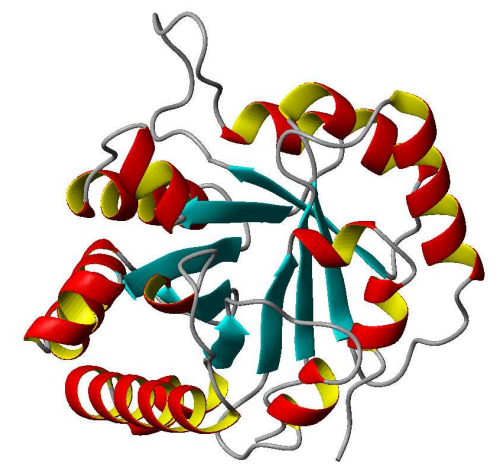

(a) Barril $\alpha / \beta$ : Barril TIM (PDB 1TIM).

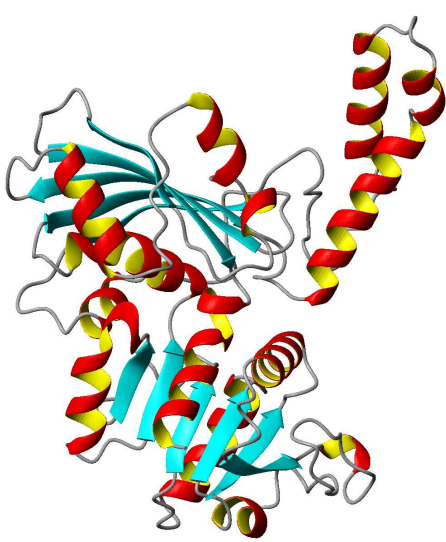

(b) Volta $\alpha / \beta$ : Asparagina Semi-Aldeída Deídrogenase (PDB 1BRM).

Figura 3.14: Motivos Estruturais de Proteínas do Domínio $\alpha / \beta$.

Existem duas principais classes de domínios, ou motivos, $\alpha / \beta$ em proteínas. A primeira classe contém um centro de oito folhas $\beta$ paralelas arranjadas juntas. As $\alpha$-hélices conectadas às folhas $\beta$ estão dispostas ao redor destas. Neste motivo, a ordem das fitas é consecutiva e a combinação das tranças das folhas $\beta$ sozinhas e a marcação adjacente das fitas produz um barril fechado (ver Figura 3.14(a)). Este domínio é freqüentemente chamado de barril TIM porque foi o primeiro descoberto nas estruturas tridimensionais de enzimas triosefosfato isomerase, que é abreviada TIM. As hélices são anfipáticas e seus lados apolares empacotados contra a face hidrofóbica de um lado da folha $\beta \mathrm{O}$ centro do 
barril $\beta$ é geralmente preenchido com as cadeias hidrofóbicas da outra face da folha $\beta$; assim nos barrils $\alpha / \beta$, a folha é quase inteiramente hidrofóbica. Segundo (Petsko and Ringe, 2004) a estrutura barril TIM é uma das poucas dobras de domínio que é relativamente fácil de reconhecer da seqüência de aminoácidos. É a dobra de domínio mais comum ainda observada, ocorrendo em $10 \%$ de todas as estruturas enzimáticas, é uma boa aposta supor que qualquer seqüência predita para ter uma fita $\beta$ relativamente apolar seguida por uma $\alpha$-hélice, repetida oito vezes, formará um barril TIM (Petsko and Ringe, 2004).

O segundo caso, consiste de estruturas com uma torção paralela ou mista de folhas $\beta$ com $\alpha$-hélices em ambos os lados da folha $\beta$, conhecida como trança $\alpha / \beta$. Neste motivo fitas $\beta$ paralelas formam uma folha aberta que é trançada em uma estrutura de formato de "sela". A ordem das fitas na folha não é consecutiva pois a folha é construída em duas ou mais metades. A primeira fita na sequência primária, em geral, forma uma fita no meio da folha. Fitas adicionais são colocadas consecutivamente para fora formando uma aresta, em seguida a cadeia retorna para o meio da folha e forma a fita que liga hidrogênios do lado de fora da primeira fita (ver Figura 3.14(b)). A partir dela a cadeia continua para fora formando a outra aresta. As hélices são inseridas em um lado para o meio da folha e no outro lado para o outro meio da folha. Novamente, as hélices tendem a ser anfipáticas enquanto que a folha é predominantemente hidrofóbica. Em sua forma clássica, o motivo trança $\alpha / \beta$ tem seis fitas $\beta$ paralelas e cinco hélices conectando como mostrado na Figura 3.14(b). Sempre que esta dobra ocorre em enzimas, a região de transferência é sempre parte do local catalítico da proteína. Outro nome para esta estrutura é dobra de ligação nucleotídica, que é indicativo da função exercida em muitas proteínas (Petsko and Ringe, 2004).

Este é o maior e mais regular de todos os domínios de estrutura, compreendendo cerca de 250 aminoácidos. Existem mais de 15 tipos de proteínas diferentes que apresentam o domínio $\alpha / \beta$, com seqüências de aminoácidos completamente diferentes. Apesar de possuírem vários arranjos diferentes, o sítio ativo nestas estruturas é na ligação do carboxi da folha $\beta$ e são alinhados pela região de loop que conecta a folha $\beta$ a $\alpha$ hélice (Branden and Tooze, 1991).

\subsubsection{Domínios $\beta$}

Domínios $\beta$ compreendem a segunda maior classe de estruturas protéicas. Contém somente folhas $\beta$, voltas apertadas e estruturas de loop irregulares. Proteínas que pertencem ao domínio $\beta$ incluem imunoglobulinas, diversas enzimas, por exemplo, Dismutase 
Superóxida e proteínas que ligam-se aos açúcares na superfície das células. Como não existem hélices para formar longas conexões entre fitas adjacentes de folha $\beta$, todas as proteínas do domínio $\beta$ contêm essencialmente estruturas $\beta$ antiparalelas, as fitas são conectadas com voltas $\beta$ e grandes loops (Petsko and Ringe, 2004).

Os padrões de conexões entre as fitas origina folhas $\beta$ com duas topologias distintas. A direção da cadeia polipeptídica determina que uma fita em uma folha $\beta$ antiparalela pode somente ligar-se a outra fita em número ímpar de fitas distante. As conexões mais comuns são com uma fita imediatamente adjacente ou um-três fitas distantes, uma fita com a terceira fita distante. Se todas as conexões ligarem fitas adjacentes, a folha $\beta$ tem um motivo estrutural up-down. Em up-down uma fita de folha $\beta$ é conectada a outra por uma curta região de loop (ver Figura 3.15(a)). O modelo mais comum deste tipo de estrutura contém oito folhas arranjadas de forma a construir o centro de uma superfamília de proteínas. Pelo menos 20 membros dessa família são atualmente conhecidos (Branden and Tooze, 1991).

A conexão com a terceira fita leva ao motivo chamado Chave-Grega (ver Figura 3.15(b)), pois lembra com o desenho de Chave-Grega em vasos antigos. Este inclue proteínas de várias funções diversas, onde a variabilidade funcional é ativada por diferentes regiões de loop que conectam as folhas $\beta$ (Branden and Tooze, 1991). Um exemplo deste motivo é a proteína pré-albumina, que contém dois motivos de Chave-Grega. Uma dobra característica das imunoglobulinas, que é também encontrada em um número de proteínas que interagem com outras na superfície da célula, é um motivo de Chave-Grega central ladeado em ambos os lados por fitas antiparalelas adicionais.

Quando folhas $\beta$ antiparalelas podem empacotar-se umas contra as outras, existem dois caminhos estrututurais, os barrils $\beta$ e sanduíches $\beta$. Em um motivo barril $\beta$, uma única folha $\beta$ forma uma estrutura cilíndrica fechada na qual todas as fitas possuem pontes de hidrogênio com outra; a última fita forma pontes de hidrogênio com a primeira. Ambos os tipos de conectividade folha $\beta$ são compatíveis com um barril $\beta$ : pré-albumina é um exemplo de barril $\beta$ construído usando motivo de Chave-Grega (ver Figura 3.15(b)), e a proteína verde fluorescente da Vitória Aequorea é um exemplo de barril $\beta$ formado de um motivo up-down (ver Figura 3.15(c)) (Petsko and Ringe, 2004).

Em um sanduíche $\beta$ duas folhas $\beta$ separadas empacotam juntas face a face como duas fatias de um pão. Este arranjo difere do barril por que a fita final de cada segmento folha não possui pontes de hidrogênio com outro. Suas potenciais ligações de hidrogênio são satisfeitas principalmente pelas interações com aas cadeias laterais e com moléculas de água. Novamente, ambos os tipos de conectividade de folhas antiparalelas podem 


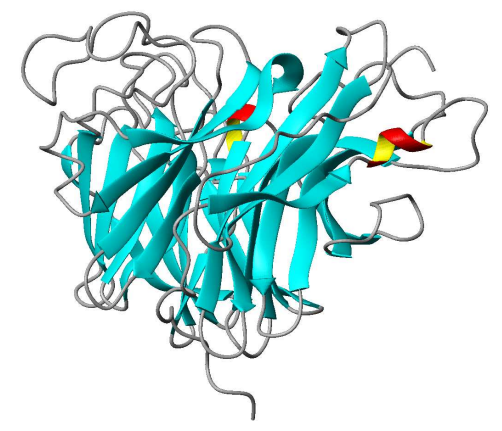

(a) Propulsor- $\beta$ Neurominidase: Motivo up-down (PDB 1A4Q).

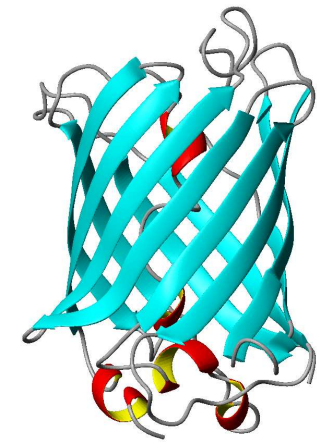

(c) Verde Fluorescente: Motivo Barril $\beta$ (PDB 1EMA).

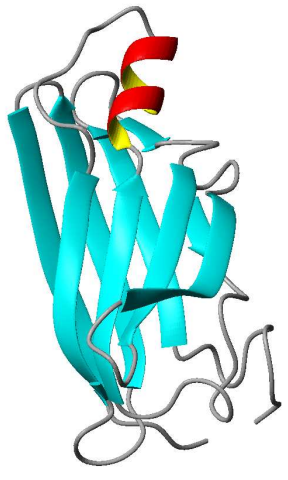

(b) Pré-Albumina: Motivo de Chave-Grega (PDB 1TTA).

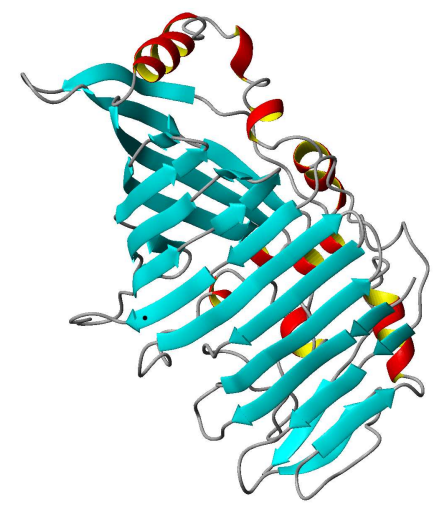

(d) Bacteroclorofila A: Motivo Rocambole (PDB 1KSA).

Figura 3.15: Motivos Estruturais de Proteínas do Domínio $\beta$.

ser acomodados nesse arranjo. A dobra da imunoglobulina é um exemplo de sanduíche $\beta$ construído com dois motivos de Chave-Grega. Uma variação desse tema é a dobra rocambole que compreende o principal domínio de proteínas de camada de virús esféricos. A proteína Bacterioclorofila A contém um sanduíche $\beta$ antiparalelo com topologia updown (ver Figura 3.15(d)).

\subsection{Determinação da Estrutura Terciária}

A estrutura terciária da proteína pode ser determinada experimentalmente por meio de dois métodos diferentes: cristalografia de raio-X e ressonância nuclear magnética (RNM). A interação dos raios-X com os elétrons em moléculas arranjadas em um cristal é utilizada 
para obter um mapa de densidade de elétrons da molécula, o qual pode ser interpretado em termos de um modelo atômico. Avanços técnicos atuais, tais como computadores poderosos incluindo trabalhos gráficos, detectores de áreas eletrônicas e muitas fontes fortes de raios-X de radiação sincontron, têm facilitado extremamente o uso de cristalografia de raio-X.

A cristalização de proteínas pode ser difícil de obter e, geralmente, requer muitos experimentos diferentes variando um número de parâmetros, tais como $\mathrm{pH}$, temperatura, concentração da proteína e a natureza do solvente. Cristais de proteínas contém vários canais e furos preenchidos com solventes, os quais podem ser utilizados para difusão de metais pesados no cristal. A adição de metais pesados é necessária para a fase da difração de raios (Branden and Tooze, 1991).

Estruturas de raio-X são determinadas em diferentes níveis de resolução. Na resolução mais baixa somente a forma da molécula é obtida, enquanto que na alta resolução a maioria das posições atômicas pode ser determinada com alto grau de exatidão. Na resolução intermediária a dobra da cadeia polipeptídica é, geralmente, revelada corretamente, bem como as posições aproximadas das cadeias laterais, incluindo seus sítios ativos. A qualidade do modelo tridimensional final da proteína depende da resolução dos dados do raio-X e do grau de refinamento (Branden and Tooze, 1991).

No método de RNM as propriedades de spin magnético do núcleo atômico da molécula são utilizadas para obter uma lista das restrições de distância entre os átomos na molécula, a partir da qual a estrutura tridimensional da molécula da proteína pode ser obtida. Este método não requer cristais de proteína e pode ser utilizado em moléculas protéicas em soluções concentradas. No entanto, sua utilização é restrita a pequenas moléculas de proteína (Branden and Tooze, 1991).

\subsection{Considerações Finais}

Como foi visto, proteínas são compostos orgânicos formados por compostos mais simples denominados aminoácidos, os quais possuem um carbono central, $C_{\alpha}$, que possui quatro grupos ligados diferentes: um grupo amino, um grupo carboxila, um hidrogênio e um radical ou cadeia lateral. Os aminoácidos são diferenciados por mudanças no radical. Pequenas seqüencias de aminoácidos são chamados polipeptídeos.

As proteínas são moléculas hierarquicamente estruturadas, ou seja, possuem uma estrutura primária, seqüência linear dos aminoácidos, estrutura secundária, conformações locais repetidas em quase todas as proteínas e a estrutura terciária, arranjo tridimensional 
da molécula protéica.

Existem três classes principais de proteínas classificadas de acordo com os tipos de motivos de estrutura secundária encontrados: domínio $\alpha$, domínio $\beta$ e o domínio $\alpha / \beta$. A estrutura terciária da proteína pode ser determinada experimentalmente por meio de dois métodos: cristalografia de raio-X e ressonância nuclear magnética.

A determinação da estrutura terciária da proteína é muito importante para que se possa determinar qual a função da proteína no organismo ao qual pertence. O conhecimento da função protéica auxilia no estudo para o desenvolvimento de novos fármacos pois, ao se conhecer a estrutura tridimensional, pode-se determinar quais compostos podem ser ligados ao sítio ativo da proteína mais adequadamente. 


\section{Capítulo 4 \\ Predição da Estrutura Terciária de Proteínas}

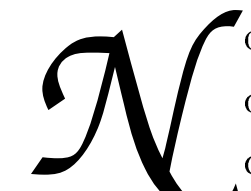

o Capítulo 3 mostrou-se que os métodos experimentais para determinação da estrutura terciária das proteínas requerem uma série de restrições para que estes possam ser utilizados. Devido a essas restrições, a investigação de métodos computacionais eficientes para a determinação da estrutura terciária é uma linha de pesquisa importante denominada predição de estrutura terciária de proteínas.

Sabe-se que as proteínas globulares (ver Seção 3.3) possuem estrutura terciária única e que essa estrutura depende unicamente da estrutura primária protéica, ou seja, da seqüência de aminoácidos (McGarrath and Judson, 1993). O processo de formação da estrutura terciária é denominado dobramento e existem algumas propriedades físicas que determinam este processo (Karplus and Shakhnovich, 1992):

- rigidez da cadeia principal (cadeia que contém todos os carbonos $\alpha$, ver Seção 3.1);

- interações entre os aminoácidos incluindo interações eletrostáticas;

- forças de Van der Waals ${ }^{1}$;

- restrições de volume;

- pontes de hidrogênio e dissulfeto;

\footnotetext{
${ }^{1}$ Forças de van der Waals são forças de atração intermoleculares capazes de mantê-las unidas.
} 
- interações dos aminoácidos com o meio aquoso.

Diversas pesquisas têm buscado elucidar o processo de como ocorre o dobramento das proteínas (Karplus and Shakhnovich, 1992), porém não existe ainda uma teoria que explique adequadamente este processo. Devido a dificuldade de se compreender o processo de dobramento de uma proteína em sua estrutura terciária, a qual é necessária para a determinação da sua função, uma alternativa tem sido a determinação da estrutura da proteína (DEP), ou seja, da proteína "dobrada". O problema de DEP pode ser visto como um problema de otimização. Vários métodos de otimização têm sido investigados para esse problema, destacando-se métodos baseados em homologia (Hilbert et al., 1993; Doolittle, 1986), threading (Baxevanis and Ouellette, 2001; Lemer et al., 1995), Ab initio (Vullo, 2002; Bonneau, 2001; Simons et al., 1999; Cui et al., 1998; Khimasia and Coveney, 1997) e semi Ab initio (Inbar et al., 2005, 2003; Ishida et al., 2003; Bowie and Eisenberg, 1994).

Devido ao grande número de graus de liberdade, relativos aos ângulos principais $\phi$ e $\psi$ (que determinam a forma da proteína) para cada valor atribuído a um desses ângulos de um aminoácido, uma nova estrutura tridimensional é obtida. Considerando que os ângulos $\phi$ e $\psi$ possam assumir $m$ valores cada um e que para cada par de valores em um resíduo obtém-se uma configuração espacial, cada resíduo pode estar em somente uma de $m^{2}$ configurações espaciais existentes. Assim, para uma proteína com $n$ resíduos têm-se $m^{2 n}$ prováveis configurações espaciais. Portanto, a determinação da estrutura de uma proteína por meio de um mecanismo de busca pelo espaço de soluções é um problema analiticamente intratável (Meidanis and Setubal, 1997).

Ao contrário de alguns problemas físicos com crescimento exponencial que têm sido resolvidos por meio de suas simetrias e leis de conservação, nas proteínas não se consegue definir claramente se existem simetrias suficientes devido às suas interações muito complexas. Além disso, apesar de serem macromoléculas, as proteínas não possuem $\sim 10^{23}$ átomos ou $1 \mathrm{~mol}$, característica necessária para garantir os mecanismos estatísticos e o tratamento termodinâmico de moléculas, os quais tornariam o problema tratável (Khimasia and Coveney, 1997).

Este Capítulo apresenta uma visão geral dos métodos computacionais para a predição da estrutura terciária de proteínas. A Seção 4.1 aborda a modelagem por homologia e seus princípios. A seguir a Seção 4.2 apresenta uma visão geral sobre a modelagem por threading. A Seção 4.3 discute os métodos Ab initio destacando as abordagens com AEs. A Seção 4.5 apresenta as considerações finais sobre este Capítulo. 


\subsection{Modelagem por Homologia}

O termo modelagem por homologia possui várias definições. Algumas restringem a frase "proteínas homólogas" somente a seqüências que possuem um ancestral comum (Doolittle, 1986). Porém, como é difícil provar ou não um ancestral para proteínas com menos de $30 \%$ de resíduos idênticos na mesma posição (ver Seção 3.1), uma alternativa, utilizada neste trabalho é definir homologia de maneira mais geral, como sendo uma similaridade estrutural.

A Modelagem por homologia, mais rigorosamente, significa predizer a estrutura terciária de uma proteína desconhecida com base em uma estrutura conhecida de uma outra proteína (homóloga). Neste contexto, é importante descobrir a quantidade de similaridade com a seqüência conhecida necessária para predizer a estrutura com exatidão. Para determinar essa similaridade, Hilbert et al. (1993), estudaram superposições de alinhamento de um grande número de estruturas conhecidas de diferentes formas e classes funcionais com diferentes graus de homologia. Com base neste estudo, Hilbert et al. sugeriram as seguintes relações entre seqüências homólogas e diferenças estruturais:

- o tamanho do núcleo da região comum diminui conforme diminui a identidade na seqüência. Alinhamentos com mais de 50\% de similaridade possuem acima de $90 \%$ de seus resíduos em regiões estruturalmente conservadas. Se a identidade na seqüência fica abaixo de 20\%, o núcleo da região comum contém cerca de $65 \%$ dos aminoácidos;

- a diferença do r.m.s (medida de desvio da distância entre as posições dos átomos da proteína com estrutura conhecida e a predita, ver Seção 7.4) dos carbonos- $\alpha$ correspondentes nas duas proteínas aumenta quando decresce a similaridade na seqüência, variando de $0.32 \AA$, com valores próximos de $100 \%$ de similaridade, até 3.66 A com similaridade em torno de $20 \%$;

- regiões estruturalmente divergentes (loops ver Seção 3.4) com mais de $50 \%$ de similaridade na seqüência possuem conformação estrutural parecida. Grandes desvios estruturais podem acontecer nas regiões de loop se a similaridade for baixa;

- a diminuição da correlação de similaridade na seqüência implica em aumento no número de inserções e/ou remoções em uma das seqüências para que se tornem iguais. Identificou-se que para um número máximo de 16 inserções e remoções, em geral, a similaridade é abaixo de 20\%. Por outro lado, praticamente nenhuma inserção e remoção é verificada com mais de $60 \%$ de similaridade. 
Embora existam exceções para essas relações gerais entre seqüência homóloga e diferenças estruturais, as observações acima são utilizadas por algumas ferramentas de predição para avaliar a exatidão em um dado nível da seqüência homóloga.

Outra questão importante para determinar a similaridade entre seqüências é "Quão grande deve ser a seqüência de resíduos idênticos ou similares para implicar em uma estrutura similar?" Kabsch and Sander (1983) demonstraram que até mesmo uma similaridade exata, em pequenos segmentos, não fornece indicação de estrutura, apresentando exemplos de pentapeptídeos idênticos que participam de diferentes estruturas em diferentes proteínas. Wilson et al. (1985) extendeu essa idéia para hexapeptídeos. No entanto, Cohen et al. (1993) examinando os hexapeptídeos concluiu que, dentro de uma classe estrutural de proteína ou domínio (ver Seção 3.5), a similaridade na estrutura de um hexapeptídeo seqüencialmente idêntico é preservada. Este último estudo motivou o desenvolvimento de algoritmos para predizer as estruturas terciária e secundária de proteínas com domínio conhecido (Boldt et al., 1995; Cohen and Cohen, 1994; Barton et al., 1993; Peitsch, 2002).

Portanto, as técnicas de modelagem por homologia têm como base o fato de que proteínas com similaridade na seqüência de aminoácidos possuem dobramento e função similares. Um dobramento desconhecido é produzido utilizando a estrutura homóloga como modelo. No entanto, é freqüente encontrar duas proteínas com baixa identidade na seqüência com estrutura terciária e função similares.

\subsection{Modelagem por "Threading"}

As abordagens de threading e modelagem por homologia são baseadas na observação de que muitas proteínas no Protein Data Bank (PDB)2 são muito similares. Como resultado disso, muitos cientistas têm conjeturado que há somente um número limitado de dobramentos de proteínas diferentes na natureza. As estimativas variam consideravelmente, mas considera-se que existam menos de 1000 dobras de proteínas. Assim, uma abordagem para a predição de estrutura terciária de proteínas é determinar a estrutura de uma nova proteína pela procura de seu melhor ajuste para alguma estrutura particular na biblioteca de estruturas. A abordagem de threading é utilizada quando a proteína não tem nenhuma proteína homóloga, mas pode ter uma estrutura tridimensional similar (Lemer et al., 1995).

O processo de determinação dos métodos de threading pode ser descrito assim: o método obtém uma seqüência de busca e tenta alinha-lá em um modelo de estrutura

\footnotetext{
${ }^{2} \mathrm{O}$ PDB é uma das principais bases de dados de proteínas com estrutura terciária determinada por meio dos métodos experimentais.
} 
escolhido aleatoriamente do conjunto das principais estruturas tridimensionais determinadas de proteínas. A seqüencia de busca é a estrutura primária de uma proteína que tem estrutura tridimensional desconhecida. As estruturas tridimensionais que compõem a biblioteca de estruturas foram obtidas por cristalografia de raio-X ou por ressonância nuclear magnética. O alinhamento da seqüência de busca com o modelo de estrutura pode ocorrer das seguintes formas:

- Alinhamento seqüência-seqüência: busca encontrar o melhor alinhamento entre a seqüência de busca e a seqüência de aminoácidos do modelo de estrutura por meio de inserções e remoções;

- Alinhamento seqüência-estrutura: a seqüência de busca é movimentada sobre a estrutura tridimensional sujeita a restrições físicas pré-determinadas referentes ao tamanho dos elementos da estrutura secundária, às regiões de loop que podem ser fixas ou variáveis dentro de um intervalo, entre outras restrições.

Para cada posicionamento da seqüência contra a estrutura, interações de pareamento e hidrofóbicas entre resíduos não locais são determinadas. Esses cálculos (termodinâmicos) são usados para determinar o alinhamento mais favorável, da seqüência questionada contra o modelo de estrutura selecionado (Baxevanis and Ouellette, 2001).

\subsection{Modelagem "Ab initio"}

Em abordagens $A b$ initio, nenhuma homologia na seqüência é necessária em relação às proteínas de estrutura conhecida. Técnicas computacionais como modelos de Cadeia de Markov, RNAs, Inteligência Artificial baseada em regras e Monte Carlo (Simons et al., 1999; Bastolla et al., 1998; O’Toole and Panagiotopoulos, 1992) têm sido utilizadas para mapear os modelos de seqüência em uma estrutura. Em alguns casos, dinâmicas moleculares podem ser utilizadas como parte de um algoritmo Ab initio. Tais dinâmicas moleculares envolvem simulações de forças atuando nas proteínas para reproduzir o processo de dobramento in silico ${ }^{3}$ (Karplus and Shakhnovich, 1992).

$\mathrm{Na}$ maioria dos casos, a estrutura tridimensional das novas proteínas necessita ser determinada por meio de técnicas $A b$ initio na qual o processo de determinação não depende da proteína ter uma dobra similar conhecida. As abordagens computacionais $A b$ initio típicas computam a estrutura tridimensional realizando buscas no espaço de conformações adequado (Vullo, 2002). Alguns modelos computacionais são baseados em

\footnotetext{
${ }^{3} \mathrm{O}$ termo in silico refere-se a processos que simulam processos naturais no computador.
} 
métodos de otimização. Este problema envolve dois aspectos: (1) a especificação da função de minimização e (2) a escolha do algoritmo de busca (Khimasia and Coveney, 1997).

As Funções de Minimização são baseadas em leis físicas de movimentação em campos potenciais cuidadosamente planejados (dinâmicas moleculares) (Vullo, 2002). Na maioria dos casos a função procura minimizar a energia livre da molécula, pois sabe-se que a estrutura nativa das proteínas tem sua energia mínima (Khimasia and Coveney, 1997).

No entanto, cálculos numéricos exatos estão além das possibilidades dos computadores no presente, limitando os resultados a somente pequenas proteínas. Outro obstáculo é representado pela diferença extremamente pequena de energia entre a estrutura nativa e a estrutura não dobrada (aproximadamente $1 \mathrm{Kcal} / \mathrm{mol}$ ).

Resumindo os principais obstáculos para esses métodos $A b$ initio são: avaliar a função de minimização para proteínas grandes e o fato de que o espaço de busca cresce exponencialmente conforme aumenta o número de resíduos da proteína. Deve-se observar também que outras informações confiáveis sobre estrutura de proteínas podem ser utilizados no processo de determinação de estrutura terciária (Cui et al., 1998):

1. Estruturas nativas de proteínas são compactas e têm um centro bem acondicionado que é altamente enriquecido com resíduos hidrofóbicos;

2. A força de interação hidrofóbica dirige o processo de dobra; dificilmente resíduos não-polares são encontrados na superfície externa da proteína;

3. Proteínas globulares (ver Seção 3.3) são organizadas com uma estrutura hierárquica; isto é, estrutura secundária, estrutura terciária e estrutura quaternária;

4. As proteínas empregam caminhos de dobra evitando extensivas buscas no espaço conformacional.

\subsubsection{Abordagens com Algoritmos Evolutivos}

Como visto, o problema de predição de estrutura é analiticamente intratável, isto é, a princípio, necessita-se de um tempo exponencial para buscar em todo o espaço para encontrar estrutura de energia mínima. Assim, são necessários algoritmos de busca computacionalmente eficientes entre os quais se destacam os AEs (Kolinski, 2004; Braden, 2002; Krasnogor et al., 1999; Khimasia and Coveney, 1997; Unger and Moult, 1993; Judson, 1993; Schulze-Kremer, 1993). 
Os Algoritmos Evolutivos (AEs) percorrem o espaço de busca, independente dos locais derivativos. O processo de seleção foca a busca nas áreas de energia mínima, enquanto que o estágio de recombinação mantém a exploração do espaço de busca (Khimasia and Coveney, 1997).

Os modelos de energia nos quais os AEs têm sido aplicados variam desde modelos lattice ${ }^{4}$ (Kolinski, 2004; Braden, 2002; Krasnogor et al., 1999; Khimasia and Coveney, 1997; Unger and Moult, 1993) até modelos de proteínas contínuas simplificadas (Judson, 1993; Judson et al., 1992; Judson, 1992; Sun, 1992), cadeia principal fixa (Schulze-Kremer, 1993; Tuffery et al., 1991), modelos full-atom de polipeptídeos específicos (McGarrath and Judson, 1993; Legrand and Kenneth, 1991) e modelos full-atom gerais (Schug and Wenzel, 2006; Cui et al., 1998; Gates, 1995). A principal diferença desses modelos consiste na forma utilizada para codificar os indivíduos no Algoritmo Evolutivo (AE).

Desses modelos pode-se destacar como mais utilizados os modelos lattice e full-atom, os quais serão discutidos a seguir, assim como uma aplicação dos mesmos.

\section{Modelos Lattice}

O modelo lattice para o problema de DEP foi proposto primeiramente por Unger e Moult (1993), sendo seguido por diversos outros grupos de pesquisa nos anos seguintes (Kolinski, 2004; Braden, 2002; Krasnogor et al., 1999; Khimasia and Coveney, 1997).

O principal motivo da utilização de modelos lattice é o de simplificar o processo de busca no AE para Determinação da Estrutura da Proteína (DEP). Porém estudos computacionais mostraram que mesmo utilizando modelos lattice o problema de DEP é intratável (Krasnogor et al., 1999). Nesses modelos cada resíduo é posicionado em um ponto de uma lattice e as mudanças de posição são de comprimento fixo (geralmente, no máximo, uma unidade em cada eixo da lattice) (Braden, 2002). As lattices utilizadas nos AEs com esse modelo são, em geral, quadrada ou cúbica. Esta simplificação torna mais fácil lidar com a complexidade computacional do problema. Apesar da simplificação, muitas características do sistema real são preservadas como, por exemplo, as interações entre os resíduos (Khimasia and Coveney, 1997).

Nos AEs para DEP com modelo lattice o cromossomo representa as posições de cada resíduo na lattice. Estas podem ser representadas por coordenadas internas ou por coordenadas cartesianas:

- Coordenadas internas: a posição do resíduo atual depende da posição do resíduo anterior, na determinação da posição de cada aminoácido na lattice. O cromossomo

\footnotetext{
${ }^{4} \mathrm{O}$ termo lattice denota uma malha quadricular, que pode ser cúbica ou quadrada.
} 
armazena qual o deslocamento dentro da lattice do resíduo atual em relação ao anterior (Khimasia and Coveney, 1997). Por exemplo, em um modelo de lattice cúbica a representação será uma seqüência de $n-1$ deslocamentos do tipo $\{U, D, L, R, F, B\}$ que correspondem, respectivamente, aos seus possíveis movimentos em um cubo para cima, baixo, esquerda, direita, frente e trás (para uma proteína de comprimento $n$ ) (Krasnogor et al., 1999);

- Coordenadas cartesianas: a posição de cada resíduo é determinada de forma absoluta, não dependendo de cálculos em relação a posição do resíduo anterior (Krasnogor et al., 1999). O cromossomo, neste caso, representará as coordenadas absolutas de cada aminoácido.

Independente da representação escolhida, geralmente, os cromossomos são strings binárias (0s e 1s) o que permite a utilização de um Algoritmo Genético (AG) simples (ver Seção 2.3), com seus operadores de crossover e mutação padrões, proposto por Holland (1975). Sendo este um dos motivos que tem impulsionado o desenvolvimento de AEs para o problema de DEP com modelos lattice.

Um exemplo de AE para DEP modelado por lattice é o proposto por Braden (2002), que utiliza um modelo de lattice cúbica. O cromossomo é uma string binária onde cada resíduo é representado por grupos de cinco bits, o comprimento total do cromossomo é dado por $n * 5$, onde $n$ é o número de resíduos. Cada grupo de cinco bits é decodificado em um inteiro entre 0 e 31 . Cada um dos 32 inteiros representa uma localização para o resíduo em relação ao anterior. Esta representação garante que cada resíduo será transladado em uma única posição, em cada eixo, comparado com o anterior. As translações podem ser observadas na Tabela 4.1, onde verifica-se que as translações em um único eixo (acima, abaixo, direita, esquerda, frente e trás) são representadas por dois inteiros.

No AE também são mantidas quatro strings constantes, ou seja, não são alteradas pelos operadores de mutação e crossover, para representar outras características da proteína no processo de otimização. As características são cadeia lateral pequena, resíduo hidrofóbico, resíduo com carga positiva e resíduo com carga negativa. É construída uma string para cada característica, onde 1 representa a presença da característica no $i$-ésimo resíduo e 0 a ausência da característica. Estas strings são utilizadas no cálculo do fitness do indivíduo (Braden, 2002).

Em geral, AEs para DEP utilizando modelos lattice tem apresentado resultados com precisão adequada e tempo de computação relativamente pequeno para proteínas pequenas compostas por dezenas ou até centenas de aminoácidos. Nas proteínas com centenas de 


\begin{tabular}{||c|c|c|c|c|c||}
\hline \hline Binário & Inteiro & Translação & Binário & Inteiro & Translação \\
\hline \hline 00000 & 0 & Acima & 10000 & 16 & Abaixo-frente \\
\hline 00001 & 1 & Direita & 10001 & 17 & Abaixo-atrás \\
\hline 00010 & 2 & Esquerda & 10010 & 18 & Abaixo-direita-frente \\
\hline 00011 & 3 & Abaixo & 10011 & 19 & Abaixo-direita-trás \\
\hline 00100 & 4 & Trás & 10100 & 20 & Abaixo-esquerda-frente \\
\hline 00101 & 5 & Frente & 10101 & 21 & Abaixo-esquerda-trás \\
\hline 00110 & 6 & Acima-direita & 10110 & 22 & Direita-frente \\
\hline 00111 & 7 & Acima-esquerda & 10111 & 23 & Direita-trás \\
\hline 01000 & 8 & Acima-frente & 11000 & 24 & Esquerda-frente \\
\hline 01001 & 9 & Acima-trás & 11001 & 25 & Esquerda-trás \\
\hline 01010 & 10 & Acima-direita-frente & 11010 & 26 & Acima \\
\hline 01011 & 11 & Acima-direita-trás & 11011 & 27 & Direita \\
\hline 01100 & 12 & Acima-esquerda-frente & 11100 & 28 & Esquerda \\
\hline 01101 & 13 & Acima-esquerda-trás & 11101 & 29 & Abaixo \\
\hline 01110 & 14 & Abaixo-direita & 11110 & 30 & Trás \\
\hline 01111 & 15 & Abaixo-esquerda & 11111 & 31 & Frente \\
\hline \hline
\end{tabular}

Tabela 4.1: Exemplo de codificação do modelo lattice. (Braden, 2002)

aminoácidos o desempenho tende a diminuir. Novos métodos tem sido propostos com o objetivo de melhorar o desempenho desses AEs.

\section{Modelos Full-atom}

Nesses modelos o cromossomo representa cada resíduo que compõem a proteína por meio de seus ângulos diedrais $\left(\phi\right.$ e $\psi$ ) e de seus ângulos da cadeia lateral $\left(\chi_{i}\right)$ (Cui et al., 1998; Merkle et al., 1996; Schulze-Kremer, 1993). As abordagens mais simples, em geral, utilizam somente os ângulos diedrais ( $\phi$ e $\psi$ ) (Schulze-Kremer, 1993).

Nos AEs utilizando esses modelos, geralmente, são necessárias propostas de novos operadores de mutação e crossover devido as seguintes características:

- o número de ângulos das cadeias laterais não é fixo (Cui et al., 1998), podendo então cada gene possuir um tamanho variável;

- os ângulos possuem intervalo de valores fixo [-180, 180];

- na maioria das abordagens, a representação binária não é utilizada para codificar os ângulos no cromossomo (Cui et al., 1998; Schulze-Kremer, 1993). 
Diversas funções de avaliação, baseadas em modelos de energia potencial, têm sido utilizadas com esses modelos. Por exemplo, Cui (1998) utiliza uma função de energia potencial que leva em consideração as interações hidrofóbicas e as interações de forças de Van der Waals. Por outro lado, Merkle (1996) utilizou uma função baseada na função de energia de CHARMM (Brooks et al., 1983).

Como exemplo de abordagem utilizando o modelo full-atom, tem-se o AE desenvolvido por Cui (1998) e seus colaboradores que utilizam uma rede neural artificial para predizer a estrutura supersecundária ${ }^{5}$. O cromossomo possui um número fixo de genes, porém os genes possuem tamanho variável de acordo com o número de ângulos de torção do aminoácido $\left(\phi, \psi\right.$ e $\left.\chi_{i} \operatorname{com} i=1 . .4\right)$. As restrições impostas pela estrutura supersecundária são utilizadas para conduzir o processo de busca do AE (Cui et al., 1998).

O tamanho da população inicial é de 500 indivíduos e esta é gerada com base nas restrições impostas pela estrutura supersecundária para os ângulos $\phi$ e $\psi$, e para os ângulos da cadeia lateral as restrições foram baseadas em uma biblioteca de rotâmeros de cadeia lateral. No operador de crossover, o corte sempre ocorre entre os genes, nunca no meio de um gene, esta restrição foi imposta para preservar as relações entre os ângulos $\phi$ e $\psi$ e entre os ângulos de torção da cadeia lateral (Cui et al., 1998). Foram propostos dois operadores de mutação, o primeiro operador pode provocar mudanças drásticas na estrutura, pois todos os ângulos da cadeia principal e lateral de um gene aleatoriamente selecionado são re-selecionados dentro de suas respectivas regiões de restrição. O segundo operador de mutação é para uma busca mais local do espaço conformacional. Quando este operador é aplicado os ângulos de torção de alguns genes são perturbados por um ângulo aleatório entre $-5^{\circ}$ e $5^{\circ}$. Utiliza-se como função objetivo uma função de energia simples que possui dois termos: um de energia de interação hidrofóbica e um de energia de força de Van der Waals (Cui et al., 1998).

Durante o processo iterativo do AE proposto por Cui et al (1998) foi utilizado um processo de fitness scaling para evitar que o melhor indivíduo domine a população e ocorra a convergência prematura do AE. O valor do fitness scaling foi utilizado para selecionar os indivíduos pais que irão reproduzir. Os 500 indivíduos pais são copiados e as cópias são perturbadas pelo primeiro operador de mutação $M 1$ vezes, podendo um mesmo indivíduo ser pertubado mais de uma vez. Uma outra cópia dos indivíduos pais e novamente as cópias são perturbadas, desta vez, pelo segundo operador de mutação, no qual $M 2$ resíduos do indíviduo é perturbado. No processo de seleção têm-se uma população intermediária com os 500 indivíduos pais, 500 indivíduos descendentes obtidos

\footnotetext{
${ }^{5}$ Motivos de estrutura secundária unidos por pequenas regiões de loop.
} 
pelo crossover e os 1000 indivíduos perturbados pelos operadores de mutação, totalizando uma população com 2000 indivíduos dos quais os 500 indivíduos com menor função de energia são selecionados para a próxima geração.

Ainda para evitar a convergência prematura e random walk (ver Capítulo 2), M1 e M2 decrescem conforme a busca procede:

$$
\begin{aligned}
& M 1=1+P * \exp \left(-g n / N_{\text {eff }}\right) \\
& M 2=1+\frac{N}{4} * \exp \left(-g n / N_{\text {eff }}\right)
\end{aligned}
$$

onde $P$ é igual a 500, $N$ é o número de resíduos na proteína, gn é a geração e $N$ eff é uma constante igual a 150 .

Este trabalho apresentou resultados satisfatórios para proteínas com dezenas de aminoácidos. Um problema observado é que, se a estrutura supersecundária é predita erroneamente para uma parte seqüencial da cadeia, ocorrem erros no processo de predição da estrutura terciária pelo AE (Cui et al., 1998).

As abordagens utilizando modelo full-atom, de uma forma geral, tem apresentado resultados com precisão e eficiência para pequenas proteínas de classes de proteínas específicas, ou seja, para determinados domínios ou famílias de proteínas.

\subsubsection{Abordagens com Algoritmos Evolutivos Multi-Objetivo}

Algoritmos Evolutivos Multi-Objetivo (AEMO), têm sido aplicados para alguns problemas de dobramento de proteínas, por exemplo, reconhecimendo da dobra de proteínas multi-classe (Shi et al., 2004), redesenho e estabilização de estruturas de peptídeos (Hohm and Hoffman, 2005) e predição de estrutura terciária de proteínas (Cutello et al., 2005; Day et al., 2002).

Na abordagem proposta por Cutello et al (2005) para o problema de predição de estrutura de proteína foi conjecturado e verificado por experimentos computacionais ser mais apropriado utilizar um modelo de otimização multi-objetivo, ou seja, modelando o problema DEP com mais de uma função objetivo. Naturalmente o problema de DEP envolve múltiplos objetivos. Com base, nestes princípios Cutello et al (2005) formularam um AEMO, onde o cromossomo é composto pelos ângulos de torção da cadeia principal e da cadeia lateral de cada resíduo que forma a proteína, a função de energia potencial utilizada é a função energia do Chemistry at HARvard Macromolecular Mechanics (CHARMM), que é formado por dois principais grupos de equações moleculares ligadas e não-ligadas (Cutello et al., 2005). O AEMO utilizado nesta abordagem é o PAES, que foi 
proposto por Knowles e Corne em 1999. A função de energia do CHARMM foi dividida em dois objetivos, o primeiro composto pelo grupo de equações moleculares ligadas e o segundo pelas equações moleculares não-ligadas.

Os resultados apresentados por esta abordagem mostram que utilizar um AEMO para o problema de Predição de Estrutura de Proteína (PSP) é uma estratégia que tem apresentado resultados relevantes. Como o AEMO produz um conjunto de soluções entre as quais não se pode dizer ${ }^{6}$ qual é a melhor, é necessário um procedimento para escolher uma solução. Nesta abordagem foi utilizado na fase de decisão uma estratégia baseada no método proposto por Branke et al (2004) (Cutello et al., 2005).

\subsection{Modelagem Semi Ab inito}

Técnicas de modelagem semi $A b$ inito utilizam bancos de dados de estruturas de proteína para fazer uma busca conformacional baseada em conhecimento. Estas abordagens são baseadas na observação que estruturas podem ser reconstruídas utilizando bibliotecas relativamente pequenas de estruturas modelo de curtos segmentos (Unger et al., 1989). De acordo com o modelo hirárquico de dobramento de proteínas proposto por Rose (1979) e por Lesk e Rose (1981), no primeiro estágio do processo de dobramento, interações de intervalo curto ocorrem e formam sub-estruturas de fragmentos locais. Então, estruturas locais relativamente estáveis unem-se a grandes unidades estruturais por meio de interações não locais. Essas interações seguem o caminho de dobramento da proteína que leva para a estrutura nativa. Uma linha de evidências experimentais sugere a existência de unidades de dobramento autonômas em domínios de proteínas, que executam um importante papel no caminho de dobramento da proteína (Inbar et al., 2003).

Abordagens que utilizam a técnica de modelagem semi $A b$ initio propõem a predição da estrutura tridimensional das proteínas com base no conceito acima, recuperando de bases de dados de pequenos segmentos ou por meio do alinhamento de sequências selecionando o segmentos consecutivos, as estruturas estáveis dos peptídeos que compõem a proteína. A próxima etapa do processo, nessas abordagens, é combinar as sub-unidades estruturais para se obter a estrutura da proteína completa. Neste processo leva-se em conta o sentido do amino terminal para o carboxi terminal para fazer a combinação das sub-estruturas (Inbar et al., 2003)

Na abordagem proposta por Inbar et al (2003) o algoritmo é divido em três etapas. Na primeira etapa a proteína alvo é quebrada em segmentos disjuntos e um modelo de

\footnotetext{
${ }^{6}$ Não se pode dizer qual é a melhor solução à partir dos multi-objetivos utilizados.
} 
estrutura é atribuído a esses segmentos. Na próxima etapa é feita montagem combinatorial dos modelos de estrutura (saída da primeira etapa), por meio de um algoritmo de docking. Na terceira etapa é realizada a complementação e refinamento do modelo completo obtido na segunda etapa. Neste estágio, o problema é reduzido ao problema de árvore geradora mínima em grafos e não se permite ajustes nas sub-unidades estruturais, somente é permitida a rotação das sub-unidades. É aplicodo um algoritmo de busca pela árvore geradora mínima para encontrar a estrutura terciária da proteína completa.

Outra abordagem semi $A b$ Initio é a proposta por Bowie e Eisenberg (1994) também utiliza a montagem combinatória de sub-unidades estruturias. Nesta abordagem as sub-unidades estruturais são recuperadas de uma base de dados de estruturas de proteínas conhecidas. Esta abordagem utiliza uma estratégia evolutiva, onde a população inicial é contruída da combinação das sub-unidades estruturais que possuem duas origens: peptídeos de tamanho fixo nove e peptídeos de tamanho entre 15 e 25 resíduos, que foram encontrados pelo melhor alinhamento da estrutura sem gaps (Bowie and Eisenberg, 1994). Primeiramente os indivíduos da população são construídos somente com peptídeos de tamanho nove sem sobreposição. Na próxima etapa dois fragmentos de tamanho nove são aleatoriamente selecionados e substituídos por um fragmento grande de tamanho entre 15-25 resíduos. Esta população de estruturas testes foi otimizada por um AE. Esta abordagem foi utilizada somente para proteínas do domínio $\alpha$.

Essas abordagens mostram que a partir de sub-unidades estruturais, obtidas por meio da recuperação de bases de estruturas ou mesmo predizendo a estrutura dos segmentos, é possível predizer a estrutura terciária de grandes proteínas.

\subsection{Considerações Finais}

Nesse Capítulo foram discutidas as principais técnicas e métodos computacionais utilizados para a predição da estrutura terciária de proteínas. Os quais têm sido desenvolvidos com o objetivo de diminuir o intervalo entre a quantidade de seqüencias de proteínas conhecidas e a quantidade de estruturas determinadas. As principais técnicas são a modelagem por homologia, a modelagem por threading e modelagem Ab initio.

Os primeiros métodos a serem desenvolvidos foram os baseados em homologia obtendo resultados satisfatórios para proteínas com alta similaridade. Porém nem sempre é possível obter uma proteína de estrutura conhecida com alta similaridade com a proteína cuja estrutura deve ser determinada. Esse fato tem limitado bastante o avanço das pesquisas nessa área, além disso, estes métodos requerem um alto esforço computacional. 
Estudos posteriores revelaram que algumas proteínas com baixa similaridade na seqüência possuíam estruturas terciárias similares, esta descoberta motivou o surgimento dos métodos de modelagem por threading. Com base em uma biblioteca de estruturas, busca-se determinar por meio de cálculos termodinâmicos, se certa seqüência de aminoácidos pode se ajustar a uma estrutura terciária conhecida. Esses métodos possuem sua relevância, mas não tem sido explorados significativamente devido a grande quantidade de cálculos necessários.

Por último, os métodos $A b$ initio, que independente de qualquer homologia ou estrutura tridimensional, buscam predizer a estrutura terciária de proteínas com base nos conhecimentos inclusos na seqüência de aminoácidos da proteína e nos conhecimentos sobre as interações bioquímicas (pontes de hidrogênio, pontes de dissulfeto e interações hidrofóbicas, entre outras). Esses métodos estão tornando-se mais importantes por estarem alcançando resultados relevantes conseguindo predizer estruturas de proteínas com relativa exatidão. Apesar dos avanços com essas técnicas, o universo de proteínas que se resolve com esses métodos restringe-se a algumas classes de proteínas. Além disso o tamanho, ou seja o número de resíduos das proteínas resolvidas também é relativamente pequeno.

Este projeto tem como objetivo desenvolver uma abordagem que busca explorar as vantagens de modelos $A b$ initio incorporando também características de modelos semi $A b$ initio para predizer a estrutura terciária de proteínas independentemente de sua classe ou tamanho. 


\section{Capítulo \\ 5 \\ AEs para Predição de Estruturas de Proteínas}

$\mathcal{U}$ m grande número de abordagens $A b$ initio utilizando AEs para a determinação da estrutura terciária de proteínas tem sido desenvolvidas nos últimos anos (Braden, 2002; Cui et al., 1998; Khimasia and Coveney, 1997; SchulzeKremer, 1993; Tuffery et al., 1991). Essas abordagens, apesar dos resultados obtidos, não conseguem solucionar o problema de predição da estrutura terciária de proteínas para todos as classes (ver Seção 3.5.1) e comprimentos de proteínas.

Por outro lado, as estruturas terciárias de pequenos polipeptídeos têm sido eficientemente determinadas por métodos $A b$ initio e a estrutura terciária de proteínas completas pode ser obtida por meio da combinação da estrutura terciária dos polipeptídeos que a compõem (Inbar et al., 2003; Ishida et al., 2003; Park, 2005).

Esta dissertação de mestrado propõem a investigação de uma nova abordagem para a predição da estrutura terciária de proteínas utilizando AEs (método Ab initio) com o objetivo de determinar a estrutura terciária de proteínas.

A abordagem proposta para o problema de DEP é composta de duas etapas. Na primeira etapa decompõe-se a proteína em polipeptídeos menores e investiga-se a aplicação de um AE para a predição das estruturas terciárias dos polipeptídeos. Nesta etapa foram utilizadas duas abordagens: um AE Mono-Objetivo (ver Seção 5.1) e um AE Multi-Objetivo (ver Seção 5.2). Na segunda etapa é proposta a investigação de um AE para fazer a montagem (ver Seção 5.3) das estruturas terciárias preditas para os polipeptídeos, obtidas 
na primeira etapa, compondo a estrutura terciária da proteína inteira. Como função de avaliação dos AEs de ambas as etapas foram utilizadas funções de energia potencial (ver Seção 5.4) baseadas nas funções disponíveis no pacote de modelagem molecular TINKER (Ponder, 2001).

Este Capítulo tem por objetivo apresentar as abordagens para predição de estruturas terciárias investigadas durante o mestrado. A Seção 5.1 apresenta o AE Mono-Objetivo desenvolvido. A Seção 5.2 discute a abordagem do AE multi-objetivo aplicado para o problema de DEP. A Seção 5.3 é abordado o AE desenvolvido para a combinação das estruturas dos peptídeos para obter a estrutura terciária da proteína. Na Seção 5.4 são discutidas as funções de energia potencial utilizadas como função de avaliação dos AEs desenvolvidos. A Seção 5.5 apresenta considerações finais.

\subsection{AE Mono-Objetivo}

Na abordagem proposta um AE Mono-Objetivo é utilizado para fazer a busca no espaço conformacional por estruturas tridimensionais de baixa energia a partir da cadeia peptídica fornecida.

No AE investigado é utilizado o modelo full-atom, no qual a estrutura terciária da proteína é representada pelos ângulos diedrais $(\phi$ e $\psi)$ e pelos ângulos principais das cadeias laterais dos aminoácidos $(\chi)$. Os resíduos presentes em proteínas possuem um, dois, três, quatro ou nenhum ângulo de torção da cadeia lateral, então o comprimento do cromossomo é no máximo de $4 N$, onde $N$ é o número de resíduos do polipeptídeo. Os ângulos foram codificados utilizando a representação de ponto flutuante, em vez de utilizar representação binária, com o objetivo de garantir maior precisão das estruturas representadas pelo cromossomo (ver Seção 2.3.1).

A seguir são apresentadas os principais componentes do AE investigado.

\subsubsection{População Inicial}

O tamanho da população inicial é de 500 indivíduos (ver Artigo (Cui et al., 1998) e Seção 5.1.4). As estruturas representadas pelos indivíduos da população inicial são construídas pela seleção aleatória dos ângulos de torção da cadeia principal $(\phi$ e $\psi)$ e da cadeia lateral $(\chi)$ nas regiões de restrição de cada resíduo. As 500 estruturas terciárias obtidas pelo processo descrito a seguir são os indivíduos pais da primeira geração do AE.

As regiões de restrição de cada resíduo para os ângulos da cadeia principal foram mapeadas utilizando o banco de dados CADB-2.0 (Mohan et al., 2005) para ângulos de 
conformação, que foi construído a partir das estruturas tridimensionais não-homólogas disponíveis nos bancos de dados de estruturas terciárias de proteínas determinadas por Ressonância Nuclear Magnética e Cristalografia de Raio-X. No processo de construção da população é selecionado aleatoriamente um par de ângulos $\phi$ e $\psi$ do conjunto de pares que mapeiam da área de restrição do resíduo, repetindo o processo para todos os resíduos que compõem o polipeptídeo.

Para os ângulos de torção das cadeias laterais as regiões de restrição são determinadas com base na biblioteca de rotâmeros desenvolvida por Tuffery et al. (2003). Esta biblioteca contém os principais conjuntos de ângulos para as cadeias laterais de cada resíduo com a sua frequência e desvio padrão. A biblioteca foi formada com base em 2926 cadeias proteícas do PDB com mais de 30 resíduos em novembro de 2003, obtidas por cristalografia de raio-X e com resolução maior do que $2.5 \AA$. Outra característica importante é que essas sequências apresentam menos de $30 \%$ de similaridade (Tuffery, 2003). Os ângulos laterais de cada resíduo são escolhidos aleatoriamente de acordo com a freqüência de ocorrência de cada conjunto nas proteínas utilizadas para construir a biblioteca.

\subsubsection{Operação de Crossover}

Pares de indivíduos pais são selecionados utilizando a seleção por torneio com três indivíduos para a aplicação da operação de crossover. Todos os indivíduos da população podem ser selecionadas para a aplicação do crossover. Três operadores de crossover foram desenvolvidos. Na aplicação da operação de crossover um dos três operadores desenvolvidos é escolhido aleatoriamente de acordo com a probabilidade pré-definida para a aplicação de cada operador.

O primeiro operador de crossover desenvolvido é um operador específico para representações utilizando números reais chamado de BLX- $\alpha$ (ver Seção 2.3.3). O Algoritmo 5.1 apresenta o pseudo-código do operador de crossover utilizado. Este operador foi desenvolvido para permitir a exploração de estruturas que não possam ser determinadas exclusivamente com os ângulos mapeados utilizados para a construção da população inicial.

Outro operador de crossover utilizado é o crossover uniforme ou de multi-pontos (ver Seção 2.3.3). Dados dois indivíduos pais um novo indivíduo é obtido com cada gene sendo escolhido de um dos indivíduos pais aleatoriamente (ver Algoritmo 5.2). Cada gene representa um resíduo, independentemente do número de ângulos que representam o resíduo.

O último operador de crossover desenvolvido aplica o crossover de dois pontos (ver Seção 2.3.3). Na aplicação deste operador dois indivíduos pais geram dois novos indivíduos 

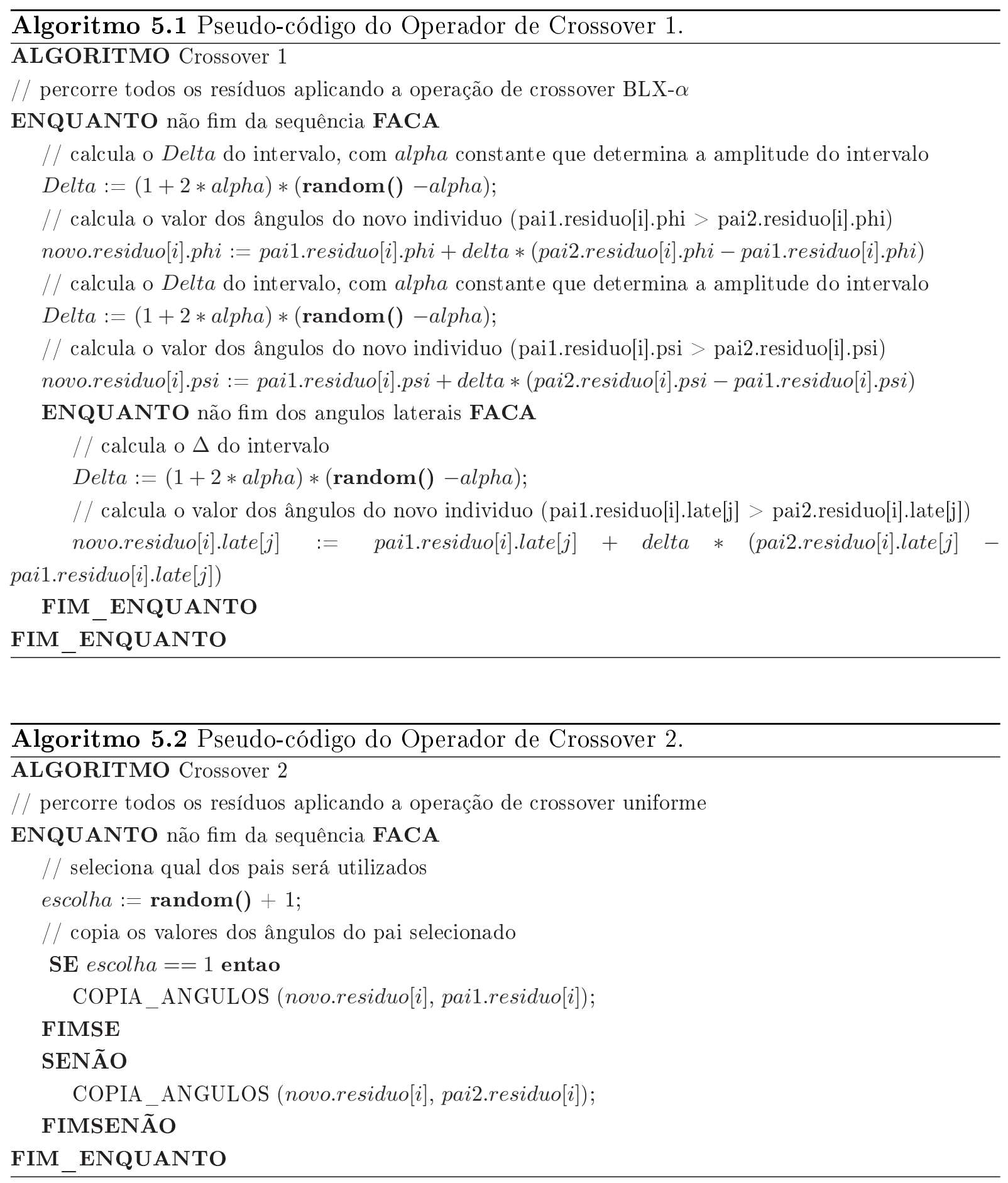

(ver Algoritmo 5.3). Os pontos de aplicação do crossover são selecionados entre os resíduos e não no meio da sequência de ângulos que representam um mesmo resíduo. Esta restrição é imposta para preservar a correlação existente entre os ângulos $\phi$ e $\psi$ nas regiões de restrição e a correlação dos ângulos das cadeias laterais na biblioteca de rotâmeros. 


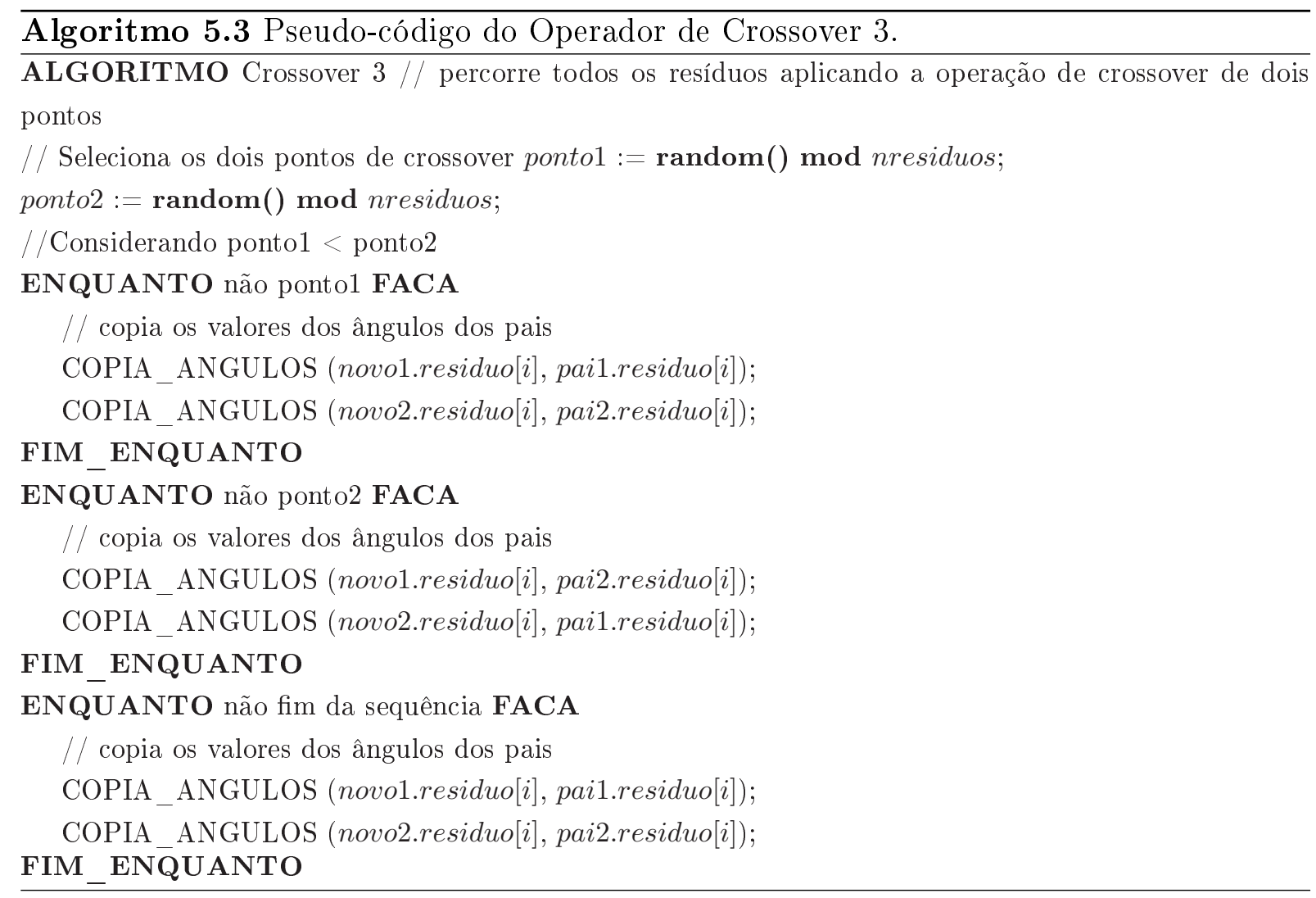

\subsubsection{Operação de Mutação}

São utilizados três operadores de mutação baseados no trabalho de Cui et al. (1998). Para a aplicação da mutação são feitas duas cópias de cada um dos indivíduos pais.

O primeiro operador de mutação utilizado pode alterar a conformação representada pelo indivíduo drásticamente. Quando este operador é aplicado todos os ângulos de torção da cadeia principal e da cadeia lateral de um resíduo aleatoriamente selecionado são reselecionados de suas correspondentes regiões de restrição. O primeiro operador de mutação é aplicado a primeira cópia feita dos 500 indivíduos pais e modifica esta população $M_{1}$ vezes, podendo o mesmo indivíduo ser modificado mais de uma vez. Em cada uma das aplicações desse operador de mutação somente um resíduo em um cromossomo é alterado, assim, somente quando o indivíduo é selecionado mais de uma vez este pode ter mais de um resíduo modificado. No Algoritmo 5.4 é apresentado o pseudo-código do operador do primeiro operador de mutação utilizado.

O segundo e terceiro operadores de mutação são similares, ambos provocam uma perturbação nos valores dos ângulos de torção da cadeia principal e da cadeia lateral de alguns resíduos do indivíduo utilizando uma distribuição uniforme. Estes operadores são 


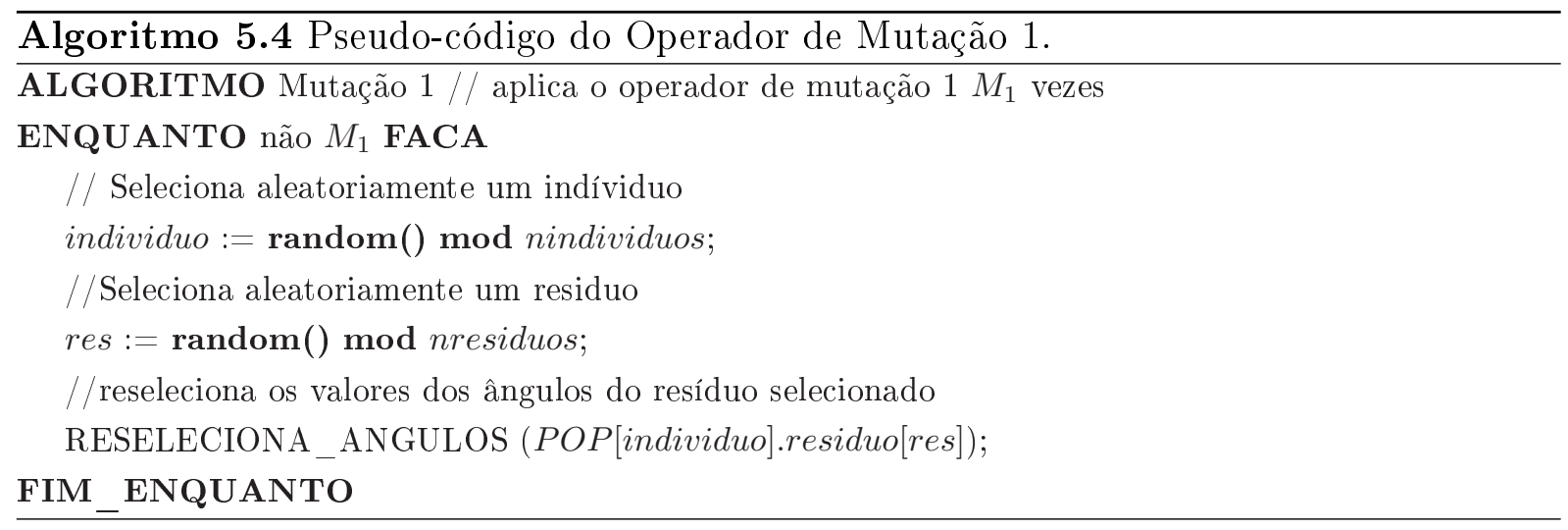

aplicados na segunda cópia dos indivíduos pais. O número de resíduos perturbado de cada indivíduo é $M_{2}$. O segundo operador provoca uma perturbação de $(r-0.5) * \Delta$, onde $r$ tem distribuição uniforme entre $[0,1]$ e $\Delta$ é diferença entre o valor do ângulo e o valor máximo em módulo permito para os ângulos $\left(180^{\circ}\right)$, no caso dos ângulos $\phi$ e $\psi$. Para os ângulos da cadeia lateral $\Delta$ é o desvio padrão para o conjunto de ângulos selecionados da biblioteca de rotâmeros.

No terceiro operador de mutação a distribuição uniforme de $r$ é alterada para o intervalo $[0,0.1]$ e a perturbação fica então alterada para $(r-0.05) * \Delta$. O valor de $\Delta$ no terceiro operador de mutação é o mesmo utilizados no segundo operador.

O segundo operador pela sua definição provoca uma perturbação maior nos valores dos ângulos e o terceiro operador uma perturbação menor. A escolha de qual dos dois operadores será aplicada é feita aleatoriamente de acordo com a taxa de aplicação definida para cada um. Quando um dos operadores é escolhido, este é aplicado para todos os $M_{2}$ resíduos do indivíduo. O processo de aplicação destes operadores pode ser visto no Algoritmo 5.5, que mostra o pseudo-código desses operadores de mutação.

Com o objetivo de evitar a convergência prematura, os parâmetros $M_{1}$ e $M_{2}$ decrescem conforme a busca procede (Cui et al., 1998):

$$
\begin{aligned}
& M_{1}=1+P * \exp \left(-g n / N_{e f f}\right) \\
& M_{2}=1+\frac{N}{4} * \exp \left(-g n / N_{\text {eff }}\right)
\end{aligned}
$$

onde $P$ é igual a 500, $N$ é o número de resíduos na proteína, gn é a geração e $N_{e f f}$ é uma constante igual a 150 (Cui et al., 1998). 


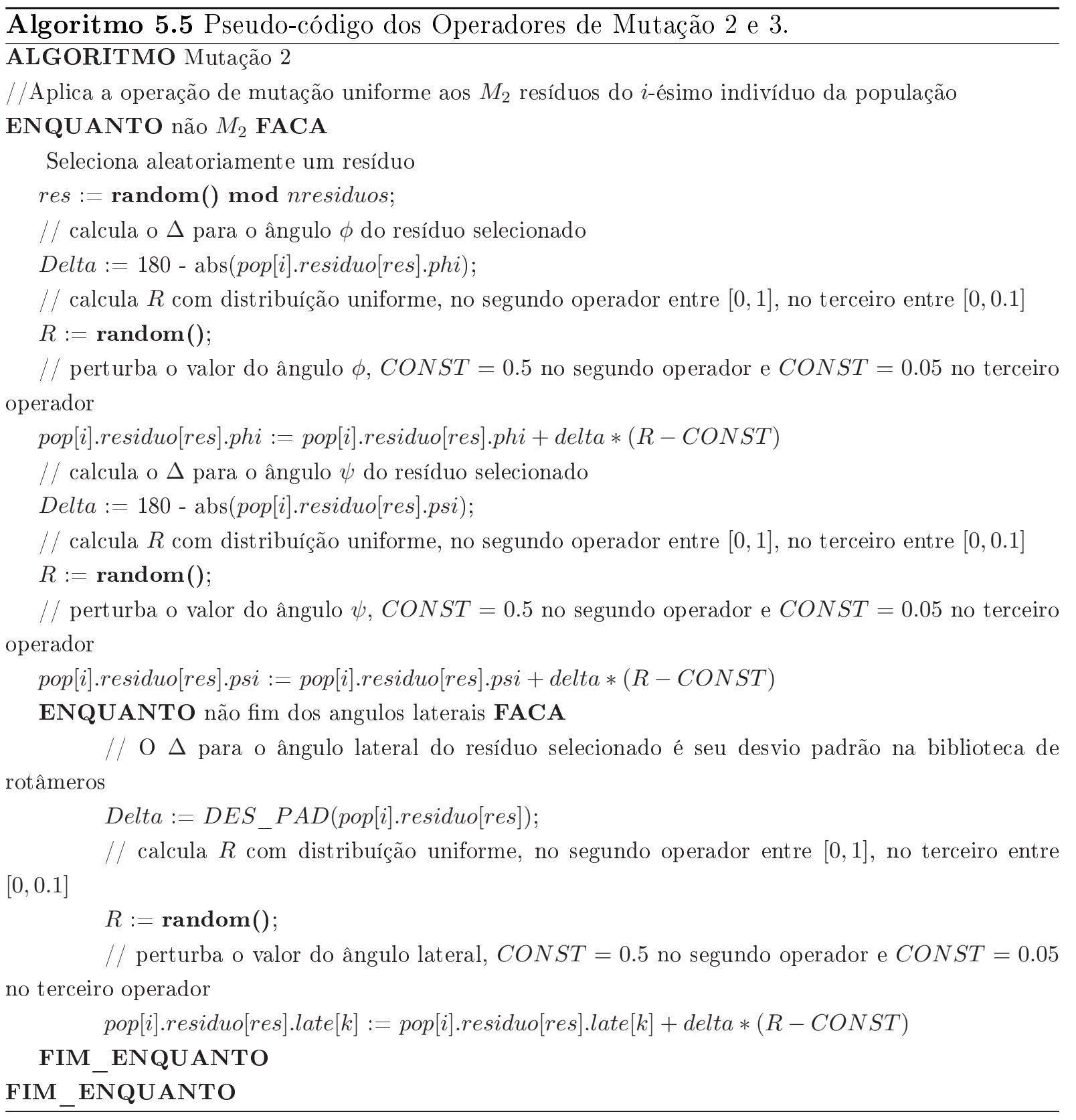

\subsubsection{Seleção}

A população ao término da aplicação dos operadores de reprodução (crossover e mutação) consiste de 500 indivíduos pais, 500 indivíduos obtidos pelo crossover e 1000 indivíduos obtidas pela mutação, formando um total de 2000 indivíduos. A aptidão de cada um desses indivíduos é calculada e os indivíduos são então ordenadas de forma crescente de acordo com valor da sua aptidão. Somente os 500 indivíduos com a melhor aptidão, ou seja, com o menor valor de energia potencial, são selecionados para passar para a próxima 
geração como indivíduos pais. Essa estratégia de seleção é a mesma utilizada por Cui et al. (1998).

\subsubsection{Convergência}

Para determinar a estrutura terciária de pequenos peptídeos o AE investigado foi executado durante 100 gerações para atingir a convergência do algoritmo com um valor de energia potencial adequado da estrutura terciária representada pelo melhor indivíduo da população.

\section{$5.2 \quad$ AE Multi-Objetivo}

Além do AE apresentado na Seção 5.1 para fazer a busca no espaço conformacional por estruturas terciárias de baixa energia potencial, propõem-se nesta Seção um AE MultiObjetivo (AEMO) para o mesmo fim. As abordagens AEMO tem como solução um conjunto de indivíduos soluções para o problema, denominada fronteira de Pareto (ver Seção-2.5).

O algoritmo NSGA-II (ver Seção 2.5.1) é utilizado nesta abordagem como AEMO base para o desenvolvimento do AEMO para o problema de DEP dos peptídeos que compõem a estrutura primária da proteína. No algoritmo NSGA-II a partir uma população de indivíduos pais, obtém-se uma população indivíduos filhos, ambas com $M$ indivíduos cada, neste caso 500 indivíduos cada uma, ambas as populações são unidas em uma população intermediária e são, então, classificadas por não-dominância obtendo as fronteiras $F_{i}$ (ver Seção 2.5). Somente 500 indivíduos sobreviverão para a próxima geração que é preenchida primeiramente com os indivíduos da fronteira $F_{1}$, se a população não está completa o processo contínua com a próxima fronteira desde que esta possa ser inteiramente copiada para a população sobrevivente. Caso contrário, é aplicado um método de distância de multidão (crowding distance) sobre os indivíduos que compõem a fronteira, ordenando os indivíduos de forma decrescente da distância de multidão. Os indivíduos de menor distância são utilizados para completar a população de sobreviventes.

No AEMO proposto são utilizados a mesma representação para codificar as estruturas no cromossomo e os mesmos operadores de crossover e mutação desenvolvidos para a abordagem proposta para o AE mono-objetivo descrito na Seção 5.1.

Um ponto importante para a aplicação do AEMO para o problema de DEP é a definição quantos objetivos serão utilizados e quais serão esses objetivos. Nesta abordagem são utilizados três objetivos que são componentes da energia potencial utilizada na AE 
mono-objetivo:

$$
\begin{gathered}
\text { Energia }_{1}=E_{\text {vdw }} \\
\text { Energia }_{2}=E_{\text {bond }}+E_{\text {angle }}+E_{\text {tors }}+E_{\text {urey }}+E_{\text {improp }} \\
\text { Energia }_{3}=E_{\text {charge }}
\end{gathered}
$$

Para uma adequada convergência do AEMO foram utilizadas 500 gerações avaliando 500 indivíduos em cada uma, obtendo ao final da execução de todas as gerações um conjunto de indivíduos soluções representando a fronteira de Pareto ótima para o problema de DEP com três objetivos.

\subsection{AE Combinatório}

Esta abordagem utiliza um AE mono-objetivo para executar a busca no espaço conformacional de estruturas tridimensionais pela estrutura terciária da proteína fazendo a combinação das estruturas tridimensionais de baixa energia encontradas pelo AE propostos nas Seções 5.1 e 5.2 para os peptídeos que compõem a proteína que se deseja predizer a estrutura tridimensional (proteína alvo).

O modelo utilizado para representar a proteína é o modelo full-atom conforme proposto para os AEs para a primeira etapa (ver Seções 5.1 e 5.2). A codificação de ponto flutuante para os valores dos ângulos no cromossomo também é a mesma dos AEs da primeira etapa.

A seguir são descritas as principais etapas do processo evolutivo do AE investigado para esta abordagem.

\subsubsection{População Inicial}

A população inicial é composta de 500 indivíduos que são construídos a partir da combinação das estruturas obtidas para os peptídeos que formam a proteína alvo. A proteína é dividida em peptídeos com tamanho de 20 aminoácidos. Caso a proteína não tenha tamanho múltiplo de 20, o último polipeptídeo conterá os aminoácidos restantes. Se a quantia de aminoácidos faltando for menor do que cinco estes aminoácidos são incluídos no último polipeptídeo construído.

Para cada polipeptídeo são recuperados os indivíduos que formam a população final do processo de predição da estrutura terciária dos peptídeos. É considerado que cada polipeptídeo pode ter um número $d_{i}$ variável de soluções finais disponíveis, sendo utilizado no processo de combinação $d$ indivíduos, onde $d=\min \left\{d_{i}\right\}$. 


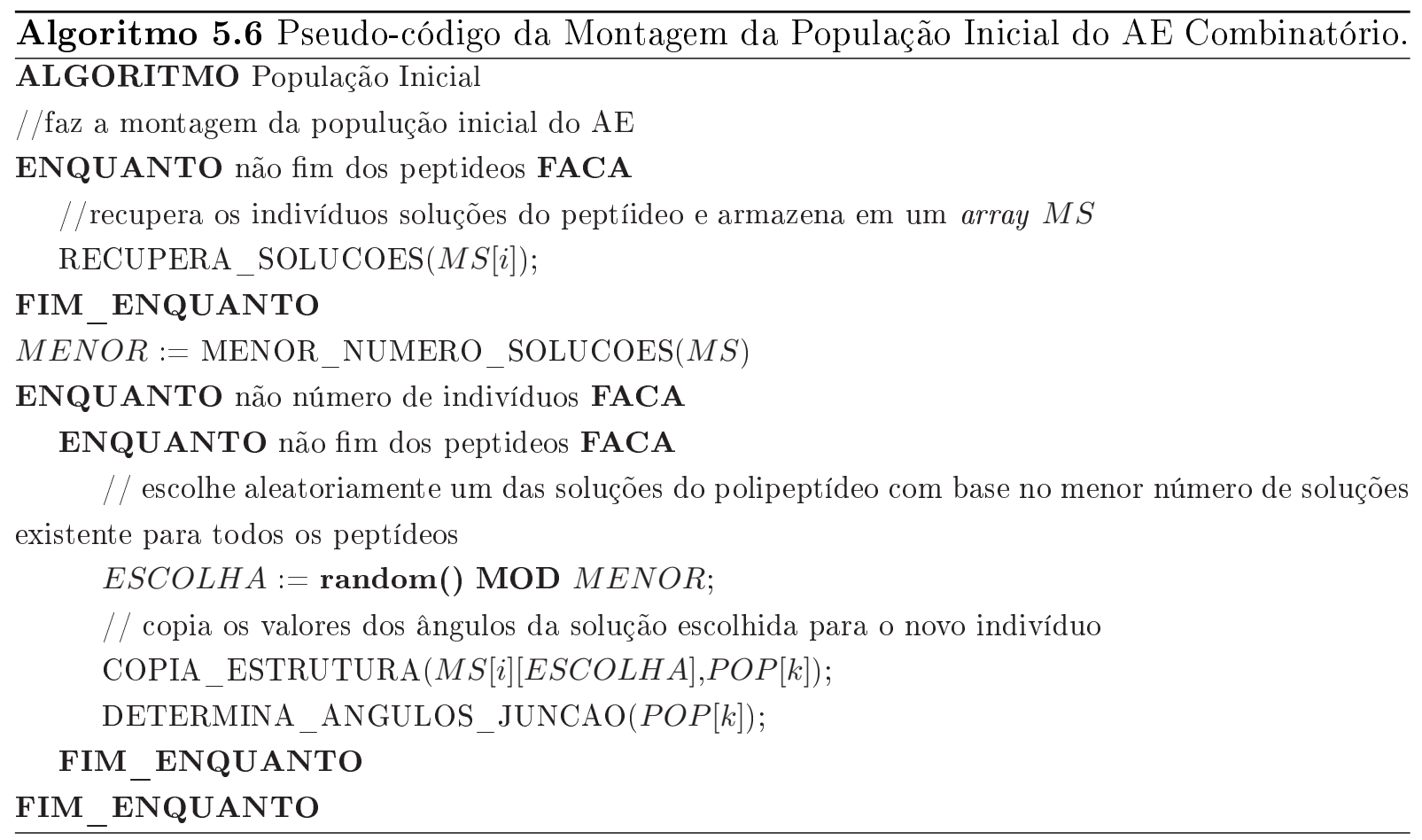

Concluída a recuperação das soluções para todos os peptídeos é iniciado o processo de combinação das estruturas tridimensionais de baixa energia de cada polipeptídeo. Nesse processo é escolhido aleatoriamente para cada polipeptídeo um número entre zero e $d$ que representa qual a estrutura representada por um indivíduo recuperado será utilizada para compor a estrutura terciária da proteína. Os ângulos $\phi$ e $\psi$ da junção de dois peptídeos adjacentes são selecionados aleatoriamente no intervalo $[-180,180]$. O processo de combinação das estruturas dos peptídeos repete-se até que tenham sido obtidos todos os indivíduos que constituíram a população inicial do AE proposto. O Algoritmo 5.6 apresenta o pseudo-código do processo de montagem da população inicial do AE proposto.

\subsubsection{Operação de Crossover}

Para aplicação da operação de crossover, pares de indivíduos pais são selecionados por torneio entre três indivíduos, podendo qualquer um dos indivíduos da população ser selecionado para reproduzir. Foram desenvolvidos dois operadores de crossover para serem utilizados nesta abordagem. O operador de crossover que será aplicado para o par de indivíduos selecionados e determinado aleatoriamente de acordo com a probabilidade de aplicação de cada um dos operadores.

O primeiro operador de crossover desenvolvido aplica o crossover para representações de ponto flutuante BLX- $\alpha$ para os ângulos de torção da cadeia principal, para os principais 
ângulos de torção da cadeia lateral de cada um dos resíduos da proteína e para os ângulos $\phi$ e $\psi$ da junção dos peptídeos aplica o crossover uniforme, ou seja, escolhe aleatoriamente um dos dois pais para copiar os valores dos ângulos para o novo indíviduo. O algoritmo 5.7 apresenta o pseudo-código deste operador de crossover desenvolvido.

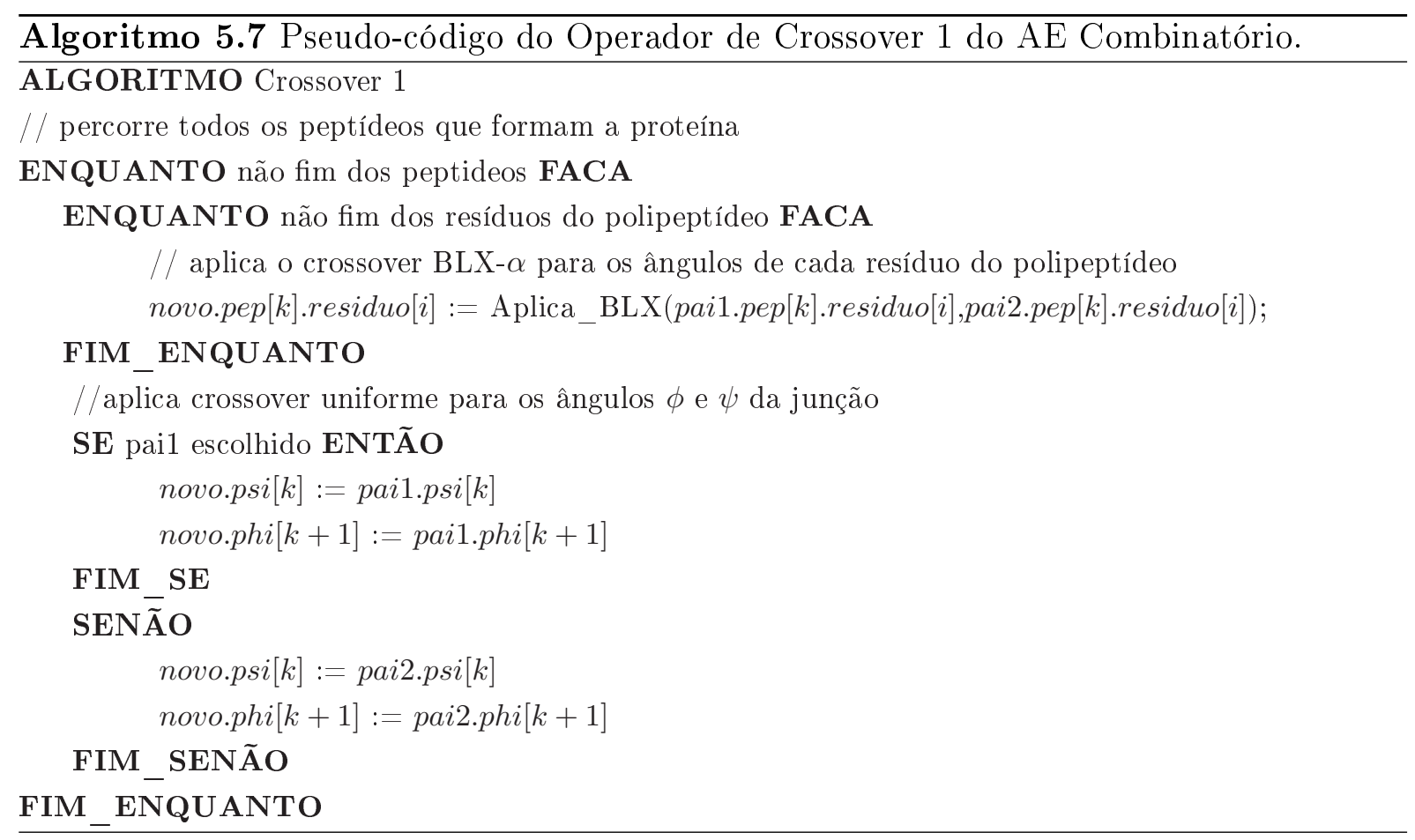

O segundo operador de crossover desenvolvido, ao contrário do primeiro, aplica o crossover BLX- $\alpha$ para os ângulos $\phi$ e $\psi$ das junções, crossover uniforme para os ângulos de torção da cadeia principal e para os principais ângulos da cadeia lateral dos aminoácidos que compõem a proteína. O pseudo-código da aplicação deste operador pode ser visto no Algoritmo 5.8.

\subsubsection{Operação de Mutação}

A operação de mutação é aplicada nos novos indivíduos obtidos após à aplicação da operação de crossover. Foram desenvolvidos dois operadores de mutação que são aplicados aleatoriamente de acordo com a probabilidade de aplicação associada a cada um. Ambos os operadores desenvolvidos aplicam a mutação uniforme que é um operador de mutação utilizado para representações de ponto flutuante.

O primeiro operador de mutação utilizado perturba somente os ângulos das junções dos peptídeos com distribuição uniforme. Definida uma taxa de mutação é determinado se os ângulos de uma junção serão perturbados ou não. Para os ângulos que são selecionados 

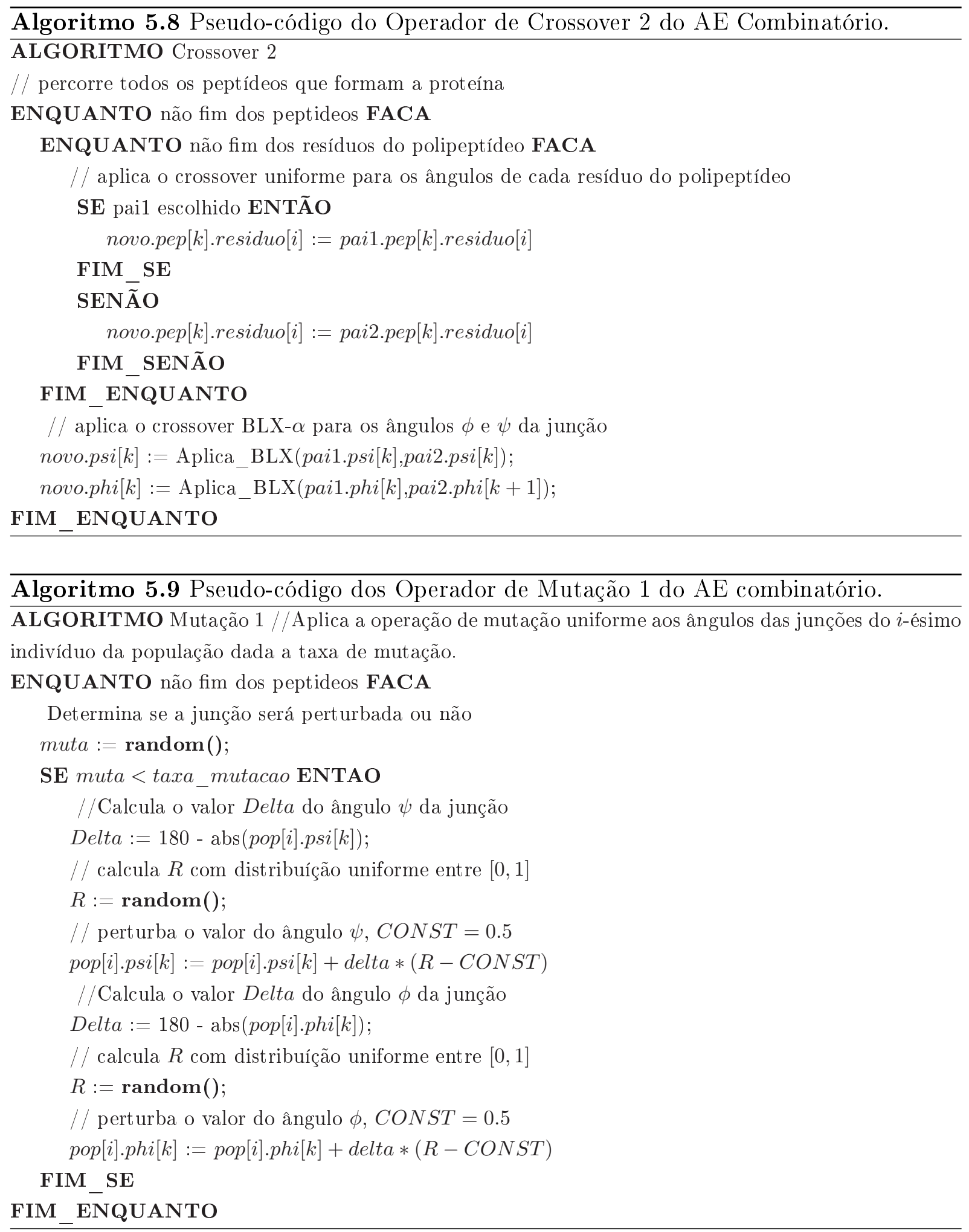

é calculada a máxima perturbação permitida, $\Delta$, observando que o maior valor permitido para um ângulo no caso das proteínas é de $180^{\circ}$ em módulo. Então é calculado o valor da 
perturbação com distribuição uniforme entre $[0,1]$, e assim o valor do ângulo é alterado. O algoritmo 5.9 apresenta o pseudo-código deste operador.

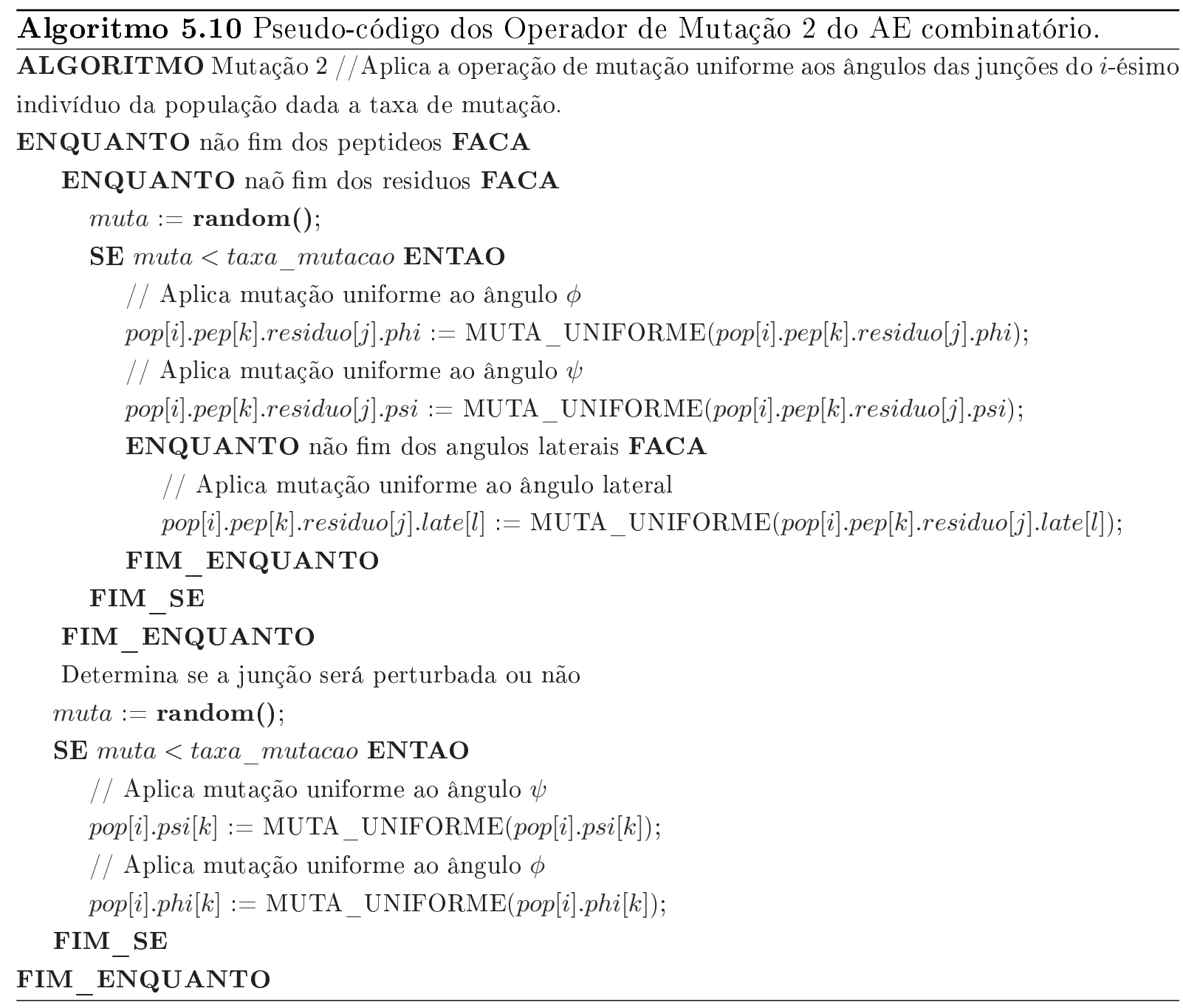

O segundo operador de mutação utilizado nesta abordagem aplica a mutação uniforme a todos os ângulos do cromosso que representa a estrutura da proteína, obedecendo a taxa de mutação definida para à aplicação da perturbação para o resíduo e para a junção. Como no operador anterior também são calculadas a máxima perturbação permitida e o valor da perturbação que será aplicado ao ângulo com distribuição uniforme. No Algoritmo 5.10 pode ser visto o pseudo-código da aplicação deste operador.

\subsubsection{Seleção}

No processo de seleção dos indivíduos que formarão a população de indivíduos pais da próxima geração é calculado o fitness dos indivíduos utilizando a função de avaliação 
(ver Seção 5.4) dos novos indivíduos obtidos pelas operações da crossover e mutação. Após os novos indivíduos terem sido avaliados é construída uma população intermediária composta pelos indivíduos pais da geração atual e pelos novos indivíduos obtidos. Esta população é ordenada de forma crescente de acordo com o seu valor de fitness. São então selecionados os 500 primeiros indivíduos da população intermediária para formar a população de indivíduos pais da próxima geração. Na última geração do AE, os 500 indivíduos selecionados formam a população final do AE.

\subsection{Função de Avaliação}

Nos AEs apresentados nas Seções 5.1, 5.2, 5.3 é utilizado como função de avaliação o somatório de sete funções de energia potencial. As funções de energia utilizadas são: energia de comprimento de ligação, energia de ângulo de ligação, energia Urey-Bradley, energia imprópria, energia de torção, energia de van der Waals e energia de carga.

A implementação das funções de energia utilizadas foi realizada com base nas implementações disponíveis no sistema de modelagem molecular TINKER, que é um pacote geral e completo para dinâmicas e mecânicas moleculares com algumas características especiais para biopolímeros. As funções disponíveis no TINKER foram desenvolvidas para utilizar diversos dos conjuntos de parâmetros comuns como, por exemplo, AMBER, CHARMM, OPLS entre outros (Ponder, 2001).

Além disso, TINKER reconhece os formatos de arquivo em coordenadas internas, onde são apresentados os ângulos de ligação, torção e comprimentos das ligações dos átomos; formato XYZ, que contém as coordenadas cartesianas da cada átomo; e o formato PDB amplamente utilizado para representar as estruturas de proteínas, ácidos nucleicos e nucleotídeos (Ponder, 2001). Com o objetivo de trabalhar adequadamente com esses formatos são disponibilizadas no pacote algoritmos de conversão de um formato para outro, que nesta abordagem foram utilizadas como base para converter a estrutura representada por ângulos no cromossomo em coordenadas cartesianas que é o formato utilizado para o cálculo da função de avaliação.

A seguir serão apresentadas as modelagens matemáticas e a interação entre os átomos representada por cada uma das funções de energia utilizadas para avaliar as estruturas representadas pelos cromossomos dos AEs desenvolvidos nesta dissertação. 


\subsubsection{Energia de Comprimento de Ligação}

As interações de comprimento de ligação são melhor compreendidas de forma funcional analisando como a energia de ligação muda de acordo com o comprimento da ligação. A energia de ligação é menor em um particular comprimento natural ou de referência $\left(r_{0}\right)$. Se a ligação é comprimida então a nuvem de elétrons dos dois átomos será gradualmente sobreposta. Se a ligação é afastada do equilíbrio a energia começa a aumentar. Eventualmente, no entanto, a ligação é disassociada, ou seja deixa de existir. A Figura 5.1 mostra o comportamento da energia em relação ao comprimento da ligação. A linha cheia mostra a aproximação harmônica por uma expansão de Taylor para pequenas variações no comprimento da ligação em relação ao valor de referência. A linha pontilhada mostra o comportamente da energia utilizando o potencial de Morse (Morse, 1929) que mais se aproxima do comportamento real da energia potencial de ligação, havendo a disassociação da ligação após um certo afastamento do comprimento de ligação ideal.

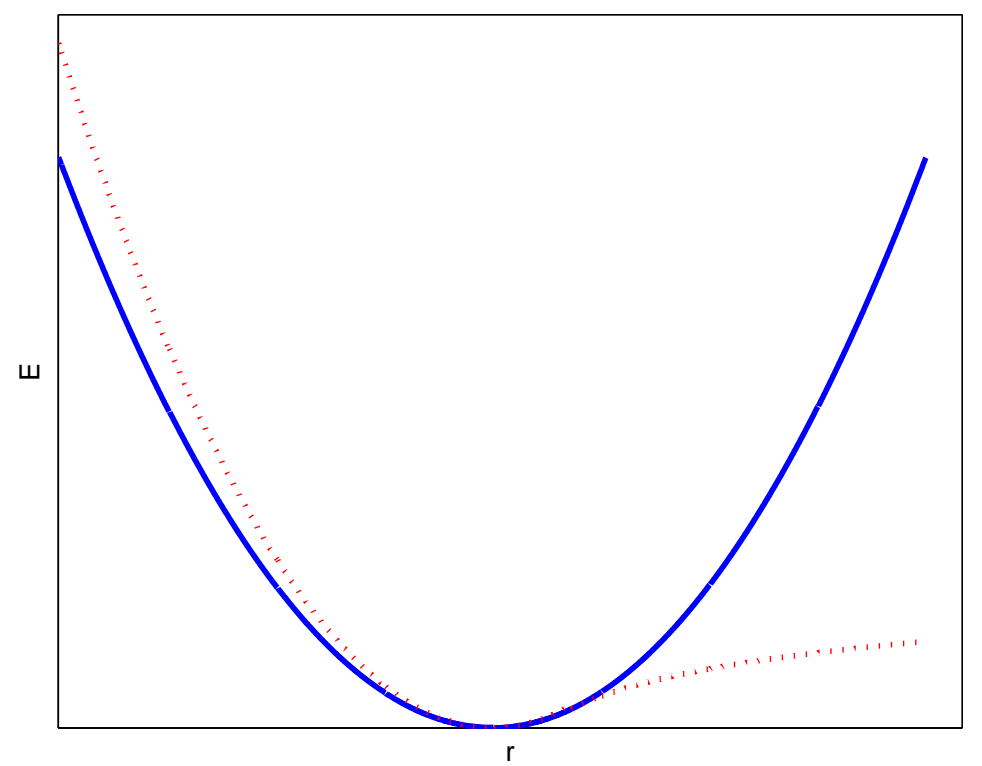

Figura 5.1: Gráfico da função de energia potencial de comprimento de ligação.

A expansão de Taylor é aplicado em $\left(r-r_{0}\right)$, onde, como mencionado, $r_{0}$ é a distância de referência e $r$ é a distância real. A equação 5.6 apresenta a expansão de Taylor utilizada para o cálculo da energia potencial de ligação. 


$$
E(r)=E\left(r_{0}\right)+\left.\frac{d E}{d r}\right|_{r=r_{0}}\left(r-r_{0}\right)+\left.\frac{1}{2} \frac{d^{2} E}{d r^{2}}\right|_{r=r_{0}}\left(r-r_{0}\right)^{2}+\left.\frac{1}{6} \frac{d^{3} E}{d r^{3}}\right|_{r=r_{0}}\left(r-r_{0}\right)^{3}+\ldots
$$

Em sua forma simplificada da equação 5.6 é concluída no termo $\left(r-r_{0}\right)^{2}$, sendo conhecida como aproximação harmônica. Considerando $E\left(r_{0}\right)=0$ e que em $r=r_{0}$ a energia é nula, assim a primeira derivada da energia é zero, e assumindo $k_{r}=\left.\frac{d^{2} E}{d r^{2}}\right|_{r=r_{0}}$ tem-se:

$$
E_{\text {bond }}(r)=\frac{1}{2} k_{r}\left(r-r_{0}\right)^{2}
$$

O comprimento de ligação de referência $r_{0}$ é freqüentemente denominado de comprimento de ligação de equilíbrio.

A energia de comprimento de ligação de referência é ligeiramente equivocada a medida que o comprimento de ligação de referência é o comprimento da ligação quando todos os termos do campo de força são atribuídos como zero. Enquanto o comprimento de ligação de equilíbrio é o comprimento da ligação para a configuração da molécula com energia mínima (i.e. quando $E_{c f}=0$ ).

As forças entre átomos ligados são muito fortes em comparação com outras forças relativas as interações entre os átomos. Esta é uma justificativa para utilizar uma aproximação harmônica. É importante lembrar que esta é uma aproximação para o potencial de comprimento de ligação real e que para grandes desvios de $r_{0}$ a aproximação harmônica não reflete o comportamento verdadeiro do potencial de comprimento de ligação. Para situações onde o comprimento de ligação pode desviar para longe de $r_{0}$ ou para exatamente calcular estruturas moleculares e frequências vibracionais, é necessário passar pela aproximação harmônica e incluir termos de ordem maior geralmente até $\left(r-r_{0}\right)^{4}$. Mesmo aumentando o intervalo de validação da equação 5.6, $E$ ainda tenderá a $\infty$ quando $r \rightarrow \infty$, que corresponde a um resultado não físico. Um potencial que satisfaz as condições exatas descritas anteriormente é o potencial de Morse (Morse, 1929):

$$
E_{\text {bond }}(r)=D\left(1-\exp \left(-\alpha\left(r-r_{0}\right)\right)\right)^{2}
$$

onde D é a energia de disassociação da ligação e $\alpha=\sqrt{\frac{k}{2 D}}$.

Nos AE proposto é utilizada como energia de comprimento de ligação o somatório da aproximação harmônica do potencial de comprimento de ligação para todas as interações de comprimento de ligação da estrutura analisada. Os valores de $r_{0}$ e de $k$, necessários para o cálculo da aproximação harmônica, são recuperados do arquivo de parâmetros charmm27 (ver Apêndice A). 


\subsubsection{Energia de ângulo de Ligação}

O ângulo de ligação $\theta$ é obtida da interação de três átomos ( $A, B$ e $C$ ) e é definido como o ângulo de ligação $A-B$ e $B-C$. Como os ângulos de ligação são encontrados (experimental e teóricamente) variando em torno de um simples valor é suficiente em muitas aplicações utilizar uma representação harmônica (ver equação 5.9), similar a energia de comprimento de ligação.

$$
E_{\text {angle }}(\theta)=\frac{1}{2} k_{\theta}\left(\theta-\theta_{0}\right)^{2}
$$

onde $\theta_{0}$ é o valor de ângulo típico, $k_{\theta}$ é a constante de força de ângulo de ligação e $\theta$ é o ângulo de ligação atual. A energia necessária para alterar o caminho de um ângulo do equilíbrio é muito menor do que a necessária para distorcer o comprimento de ligação, então, conseqüêntemente as constantes de força de ângulo de ligação são proporcionalmente menores do que as constantes de força de comprimento de ligação. Assim como no caso da energia de comprimento de ligação, quando mais termos são adicionados a equação 5.9 mais exatidão é obtida no resultado.

Nos AEs propostos é utilizada a equação 5.9 para compor função de avaliação dos indivíduos. Os valores dos parâmetros $k_{\theta}$ e $\theta_{0}$ utilizados são os disponíveis no arquivo de parâmetros charmm27 (ver Apêndice A). O termo de energia de ângulo de ligação que compõem a função de avaliação do AE é o somatório de todas as interações de ângulo de ligação da estrutura que está sendo avaliada.

\subsubsection{Energia de ângulo de torção}

Os ângulos de torção de rotação são argumentados como o mais importante dos termos intramoleculares em um campo de força. Como tal é surpreendente que alguns campos de força omitam as interações de ângulo de torção e em vez disso, tentem modelar barreias rotacionais por uma combinação de interações não ligadas. Interações de ângulo de torção são diferentes das interações de comprimento de ligação e ângulo de ligação em dois importantes caminhos. O primeiro é que as barreiras de rotação internas são baixas comparadas as outras interações, significando que mudanças nos ângulos diedrais podem ser grandes, e segundo o potencial de torção, $E_{\text {tors }}$ é periódico por meio de uma rotação de $360^{\circ}$. O primeiro implica que seria inapropriado aproximar $E_{\text {tors }}$ por uma série de Taylor. Além disso, $E_{\text {tors }}$ pode ser utilizada em muitas diferentes formas dependendo dos átomos formando-o. Assim a forma funcional escolhida deve ser capaz de modelar amplamente diferentes potenciais. 
É comum modelar as interações de torção utilizando uma série de Fourier:

$$
E_{\text {tors }}(\phi)=\sum_{n} \frac{1}{2} V_{n} \cos (n \phi)
$$

onde $n$ é o número de fases utilizadas, $V_{n}$ são as constantes de força de rotação de torção e $\phi$ é o ângulo de torção atual. É costume mover o zero do potencial e incluir fatores de fase ficando a equação como segue:

$$
E_{\text {tors }}(\phi)=\sum_{n} \frac{1}{2} V_{n}\left(1+\cos \left(n \phi-\gamma_{n}\right)\right)
$$

Os ângulos de fase $\gamma_{n}$ são geralmente escolhidos de forma que termos com $V_{n}$ positivo tenham energia mínima em $180_{o}$.

Na Figura 5.2 podem ser vistas as três primeiras fases da equação 5.11, a linha cheia apresenta o gráfico da equação para $n=1$, a linha pontilhada para $n=2$ e a linha tracejada o gráfico da equação para $n=3$. A equação 5.11 é utilizada para compor a função de avaliação do AEs desenvolvidos sendo o termo de energia de torção o somatório de todas as interações de torção da estrutura da proteína que está sendo avaliada. Os parâmetros $V_{n}$ e o ângulo de fase utilizados estão disponíveis no arquivo de parâmetros charmm27 (ver Apêndice A).

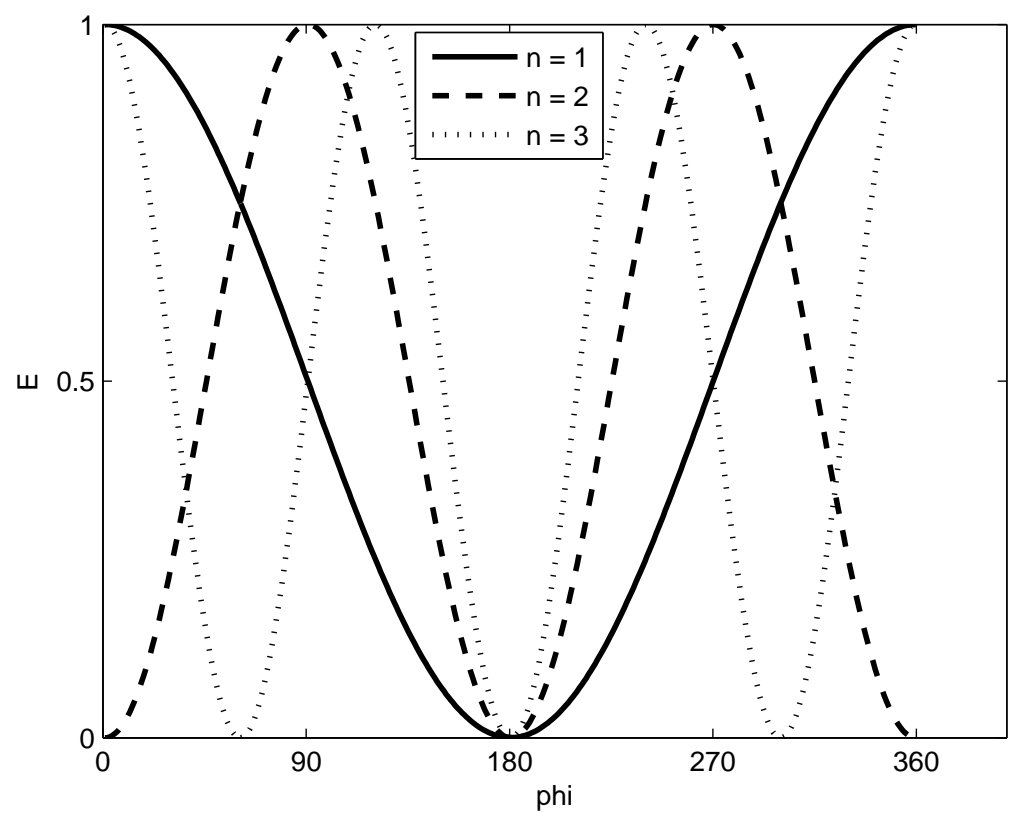

Figura 5.2: Gráfico da função de energia potencial de torção. 


\subsubsection{Energia Urey-Bradley}

Os campos de força mais elaborados incluem o termo de energia Urey-Bradley, que refere-se as interações entre pares de átomos separados por duas ligações atômicas, conhecida como interação $1: 3$ átomos. Estas interações são calculados utilizando um termo de aproximação harmônica da distância entre os àtomos $i, j$, como o utilizado para energia de comprimento de ligação e energia de ângulo de ligação.

A expressão utilizada para a energia de interação Urey-Bradley é dada pela sequinte equação:

$$
E_{\text {urey }}(s)=\frac{1}{2} k_{\text {urey }}\left(s-s_{0}\right)^{2}
$$

onde, $k_{\text {urey }}$ é a constante de força da interação Urey-Bradley e $s_{0}$ é a distância ideal entre os átomos $i$ e $j$.

Na função de avaliação dos AEs desenvolvidos é utilizado o termo de interação UreyBradley fazendo-se o somatório de todas as interações presentes na estrutura analisada. Os parâmetros $k_{\text {urey }}$ e $s_{0}$ utilizados estão disponíveis no arquivo de parâmetros charmm27 (ver Apêndice A).

\subsubsection{Energia Imprópria}

Energia imprópria está associada com deformações dos ângulos de torção impróprios. Estes ângulos de torção referem-se a átomos com hibridização $s p 2$, que geram deformações fora do plano. O termo de interações impróprias, também só é utilizado é campos de força mais elaborados.

Para o cálculo da energia referente as interações de ângulos de torção impróprios é utilizada uma aproximação harmônica dada pela equação seguinte:

$$
E_{\text {improper }}(\omega)=\frac{1}{2} k_{\text {improper }}\left(\omega-\omega_{0}\right)^{2}
$$

onde $k_{\text {improper }}$ é a constante de força imprópria e $\omega_{0}$ é o ângulo de torção impróprio ideal. Os valores utilizados para estes parâmetros na função de avaliação dos AEs desenvolvidos está disponível no arquivo de parâmetros charmm27 (ver Apêndice A). Para o cálculo da energia imprópria da estrutura que está sendo avaliada é utilizado o somatório de todas as interações de impróprias da molécula. 


\subsubsection{Energia de van der Waals}

Van der Waals é uma força elétrica relativamente fraca, que atrai moléculas neutras em gases nos estados gasoso, sólido e líquido, e na maioria dos líquidos e sólidos orgânicos (Service., 2006). A interação de van der Waals entre dois átomos faz o balanceamento entre forças de atração e repulsão. A força de repulsão aparece em curtas distâncias, onde a interação elétron-elétron é forte. A força de atração, também conhecida como força de dispersão, aparece das flutuações na distribuíção de carga da nuvem de elétrons. A flutuação na distribuíção de elétrons em um átomo ou molécula origina um dipolo instantâneo que, em volta, induz um dipolo em um segundo átomo ou molécula originando uma interação atrativa. Cada um desses dois efeitos é igual a zero quando a separação atômica $r$ é infinita e torna-se significante conforme a distância diminui. A interação atrativa possui alcance maior do que a repulsão, mas conforme a distância torna-se curta, a interação repulsiva torna-se dominante. O posicionamento dos átomos em distâncias ótimas estabiliza o sistema. Ambos os valores de energia mínima $E^{*}$ e separação ótima dos átomos $r^{*}$ (que é aproximadamente igual a soma dos raios de van der Waals dos átomos) depende do tipo químico desses átomos.

A interação de van der Waals é freqüêntemente modelada utilizando o potencial de Leonnard-Jones 6-12 que expressa a energia de interação utilizando constantes $A$ e $C$ dependentes do tipo do átomo. Os valores de $A$ e $C$ podem ser determinados por uma variedade de métodos, como distância dos não ligados em cristais e medidas de dispersão na fase gasosa. A equação 5.14 é a forma geral do potencial de Leonnard-Jones, onde $r=\frac{r_{i, j}}{R_{i}+R_{j}}$.

$$
E_{v d w}=\sum_{i, j} \frac{A_{i, j}}{r^{12}}-\frac{C_{i, j}}{r^{6}}
$$

As interações de van der Waals são uma das mais importantes para a estabilidade de macromoléculas biológicas. Estas interações são calculadas sobre pares de átomos. Em princípio, todas as interações de todos os pares de átomos deveriam ser avaliados; neste caso, o número de interações aumenta com o quadrado do número de átomos para o modelo da equação 5.14. Com o objetivo de aumentar a velocidade de computação, a interação entre dois átomos separados por uma distância maior do que a distância previamente definida, distância de corte no nosso caso $r_{i, j}>8$, são ignoradas. Outro valor de corte estabelecido é quando a distância entre os átomos se torna menor que uma distância pré-definida, conhecido como corte de diminuição, pois neste caso $E_{v} d w \rightarrow \infty$, como pode ser observado na figura 5.3 que mostra o gráfico da função de van der Waals 
em sua forma padrão.

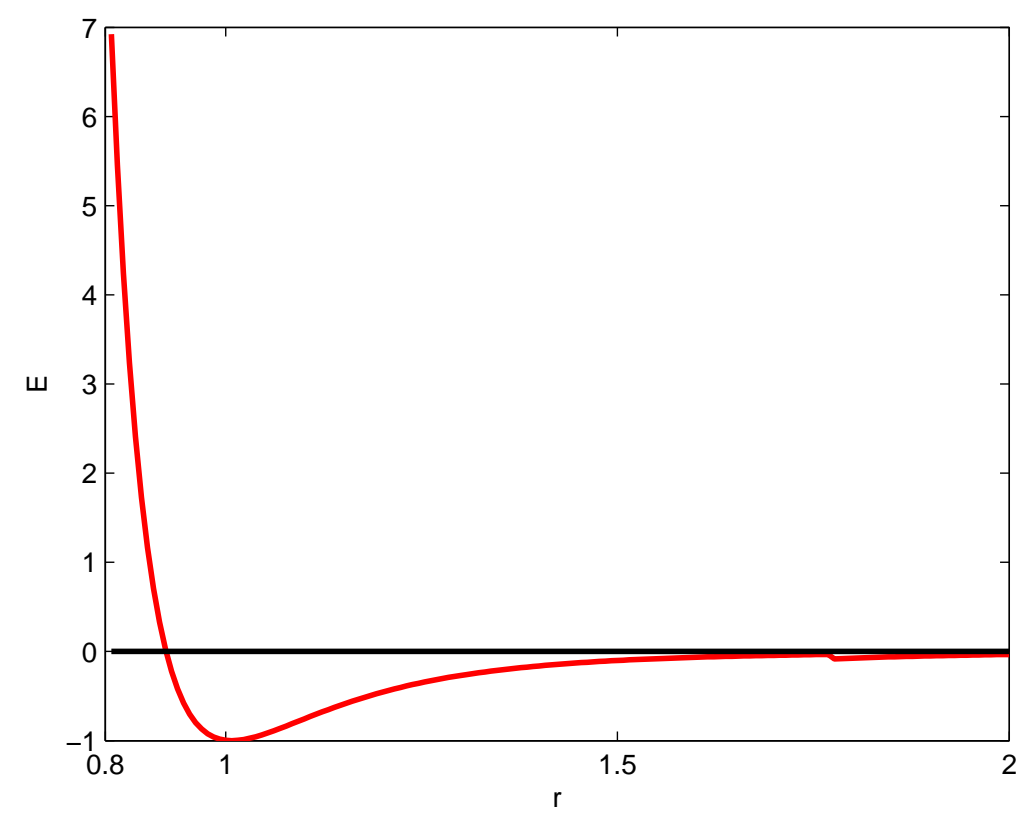

Figura 5.3: Gráfico da função de van der Waals na forma padrão.

Nos AEs desenvolvidos utilizou-se como termo de van der Waals o potencial de Leonnard-Jones com duplo loop e com corte de $8 \AA$ para as interações de van der Waals. A equação a seguir é a formulá utilizada para o cálculo das interações de van der Waals:

$$
E_{v d w}=\sum_{i=1}^{i=n-1} \sum_{j=i+1}^{j=n} f_{v} d w\left(\frac{R_{i}+R j}{r_{i, j}}\right)
$$

onde, $n$ é o número de átomos da molécula, $R_{i}$ e $R_{j}$ são os raios de van der Waals dos átomos $i$ e $j$, e $r_{i, j}$ é a distância entre os átomos $i$ e $j$. A função $f_{v d w}$ é o potencial de van der Waals com um valor de corte de diminuição em curtas distâncias (ver Figura 5.4), dada por:

$$
f_{v d w}=\left\{\begin{aligned}
1 r^{12}-2 r^{6} & \text { se } r<1.25 \\
C & \text { se } r \geq 1.25
\end{aligned}\right.
$$

onde, $r=\frac{R_{i}+R j}{r_{i, j}}$ e $C$ dado pelo valor de $1 r^{12}-2 r^{6}$ com $r=1.25$. Esta função de van der Waals com valor de diminuição impede que o potencial de van der Waals tenda a infinito quando a distância entre os dois átomos for pequena, nesse caso $25 \%$ menor do da soma dos raios de van der Waals dos átomos. 


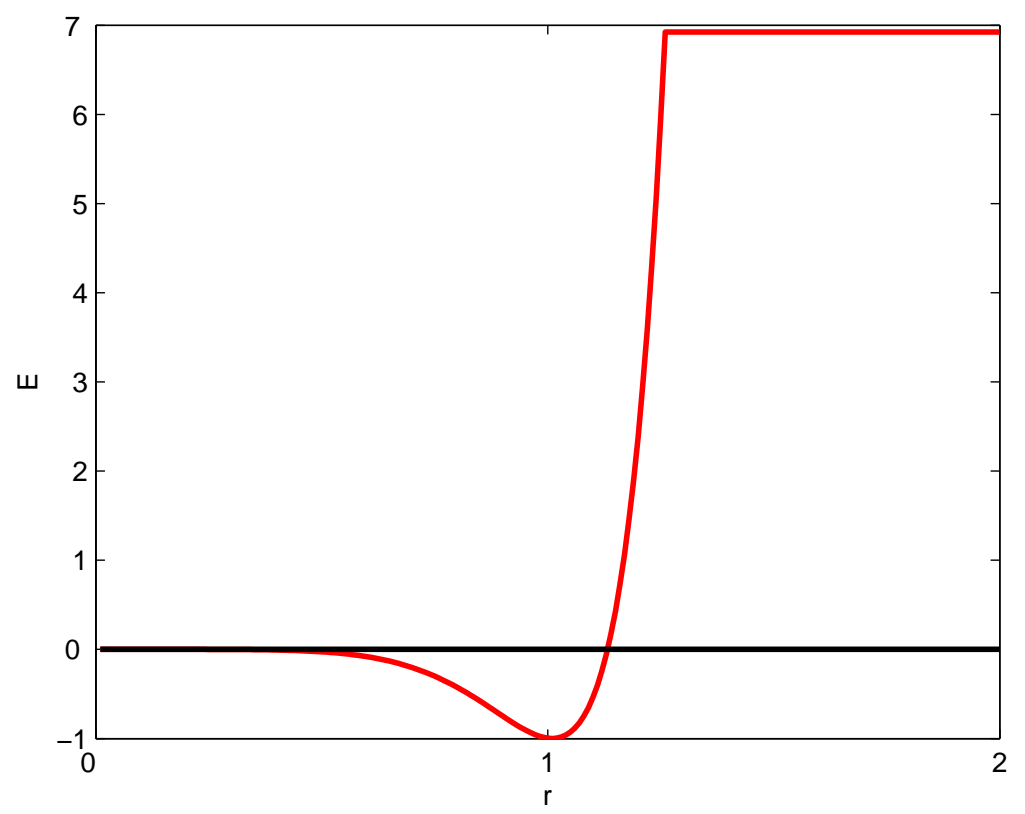

Figura 5.4: Gráfico da função de van der Waals aplicada nos AEs.

\subsubsection{Energia Eletrostática ou de Carga}

A interação eletrostática entre um par de átomos é representada pelo potencial de Coulomb apresentado na equação 5.17, onde $D$ é a função dielétrica efetiva para a média e $r$ é a distância entre dois átomos tendo cargas $q_{i}$ e $q_{j}$.

$$
E_{\text {charge }}=\sum_{i, j} \frac{q_{i} q_{j}}{D r_{i, j}}
$$

Considerando que as cargas $\left(q_{i}\right.$ e $\left.q_{j}\right)$ dos átomos não varia tem-se que a energia eletrostática varia de acordo com a distância entre os átomos. Assim, ficando-se o produto das cargas $q_{i}$ e $q_{j}$ como positivo, e variando o tamanho da distância entre os átomos obtêm-se o gráfico apresentado na figura 5.5. Neste gráfico observa-se que conforme a distância entre os átomos diminui a energia tende a infinito e que quando a distância aumenta a energia tende a zero. Como no caso da energia de van der Waals para a energia eletrostática com o objetivo de aumentar a velocidade computacional é interessante estabelecer um valor de corte determinando a maior distância em que a interação eletrostática será considerada. Caso sejam consideradas todas as interações tem-se um crescimento de acordo com o quadrado do número de átomos da molécula. Também é interessante analisando o comportamento da função eletrostática estabelecer um valor de diminuição da energia 


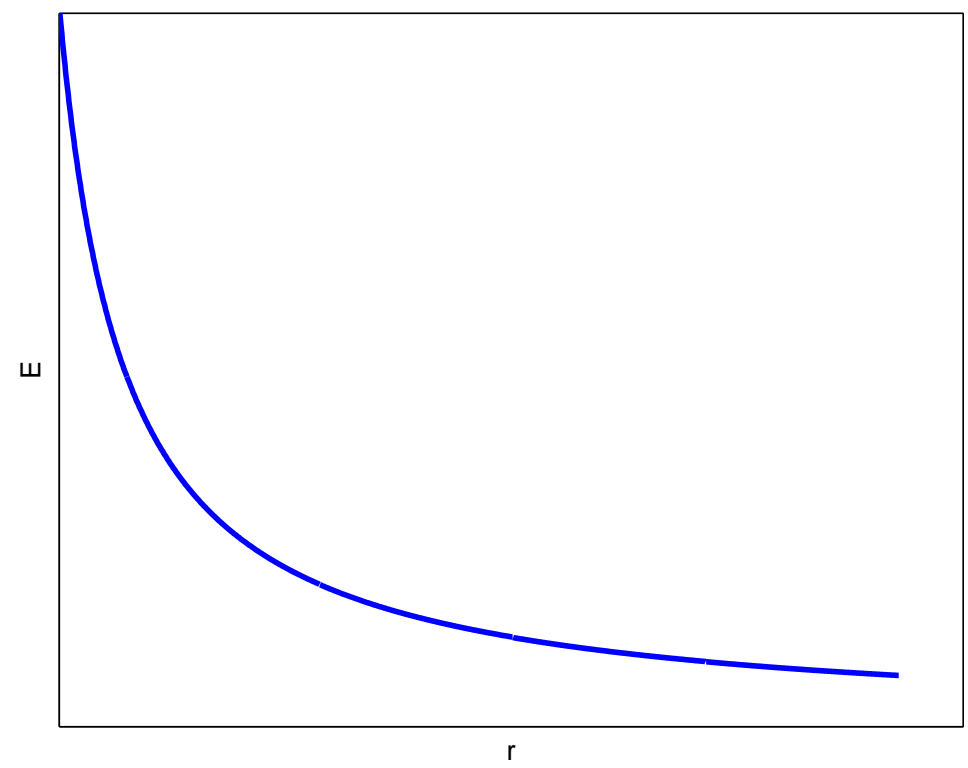

Figura 5.5: Gráfico da função de energia eletrostática.

potencial. Estes dois valores de corte foram adotados no cálculo do termo de energia eletrostática da função de avaliação dos AEs desenvolvidos, sendo a distância máxima considerada de $13 \AA$ entre os átomos e o corte de diminuição é o mesmo considerado para a energia de van der Waals, ou seja, a distância entre os átomos deve ser maior do que $75 \%$ da soma dos raios de van der Waals do par de átomos.

\subsection{Considerações Finais}

Nesse Capítulo foi apresentada a proposta de trabalho desenvolvida no Mestrado pela candidata. Este trabalho tem como objetivo explorar e investigar abordagens utilizando AES para a predição da estrutura terciária de proteínas. Para tanto foram utilizados três AEs, um AE mono-objetivo e um ae multi-objetivo para modelagem dos pequenos polipeptídeos e um AE para a combinação das estruturas dos peptídeos formando a estrutura terciária da proteína. O processo de predição da estrutura terciária da proteína se divide em duas etapas. Na primeira etapa são modelados os peptídeos que compõem a proteína e na segunda etapa é feita a combinação das estruturas resultantes para os peptídeos na primeira etapa do processo.

Foi apresentada neste capítulo a função de avaliação dos AEs propostos composta por funções de energia potencial e utilizada para avaliar as estruturas representadas pelos 
cromossomos com o objetivo de buscar pelas estruturas de baixa energia potencial. As funções utilizadas são energia de comprimento de ligação, energia de ângulo de ligação, energia de ângulo de torção, energia de Urey-Bradley, energia imprópria, energia de van der Waals e energia eletrostática. 


\section{Capítulo \\ 6 \\ Resultados Experimentais}

Neste Capítulo são apresentados os casos de teste e os resultados obtidos pelas abordagens utilizando algoritmos evolutivos (AEs) aplicadas ao problema de determinação de estrutura terciária de proteínas (DEP) descritas no Capítulo 5. Para avaliação dos resultados são utilizados dois critérios que medem a capacidade preditiva dos algoritmos.

Durante as etapas iniciais de desenvolvimento dos AEs foram realizados diversos conjuntos de testes com polipolipeptídeos sintéticos utilizados na literatura (Cutello et al., 2005) como casos de teste dos algoritmos propostos para o problema de DEP. Esses testes preliminares foram importantes para o refinamento e adequação das implementações desenvolvidas, principalmente para as implementações das funções de energia potencial, utilizadas como fitness nos AEs. Porém, na ausência da estrutura real desses polipeptídeos, optou-se por aplicar a versão atual dos AEs para um segundo conjunto de teste composto por proteínas reais, os resultados com este conjunto de teste são apresentados neste Capítulo.

A Seção 6.1 apresenta o critério de avaliação da capacidade preditiva dos algoritmos utilizados na literatura para validação das abordagens propostas. Na Seção 6.2 são apresentados os casos de teste e os resultados obtidos pela abordagem investigada nesta dissertação. Essa Seção é dividida em quatro sub-seções que descrevem separadamente os testes para cada a um dos algoritmos propostos. A Seção 6.2.1 apresenta os testes aplicados ao AE mono-objetivo e seus resultados. A Seção 6.2.2 relata os testes efetuados no AE combinatório utilizando as saídas do AE mono-objetivo. Os testes efetuados para o AE multi-objetivo podem ser vistos na Seção 6.2.3. A Seção 6.2.4 apresenta os teste 
aplicados ao AE combinatório com as saídas do AE multi-objetivo.

\subsection{Avaliação dos Resultados}

A capacidade preditiva dos AEs descritos no Capítulo 5 para a determinação da estrutura terciária de proteínas é medida pela comparação das coordenadas dos átomos da estrutura correta com a estrutura predita. Um critério de comparação das coordenadas utilizada para avaliar a exatidão da predição da estrutura terciária da proteína é o erro da matriz de distância (DME, do inglês Distance Matrix Error). Seja $X$ a matriz das distâncias de uma estrutura (possivelmente conhecida), onde $x_{i, j}$ é a distância do átomo $i$ ao átomo $j$ na estrutura, e $Y$ a matriz das distâncias da segunda estrutura (possivelmente predita), onde $y_{i, j}$ é a distância do átomo $i$ ao átomo $j$ na segunda estrutura. $D M E$ é definido como a média da diferença das matrizes de distância $X$ e $Y$ (ver equação 6.1).

$$
D M E=\sqrt{\frac{\sum_{i=1}^{n-1} \sum_{j=i+1}^{n}\left(x_{i, j}-y_{i, j}\right)^{2}}{\frac{n(n-1)}{2}}}
$$

onde $n$ é o número total de átomos da estrutura. Quanto mais baixo for o valor do $D M E$ mais exata é a predição da estrutura terciária da proteína. O $D M E$ verifica a similaridade do enovelamento entre as estruturas real e predita.

\subsection{Casos de Teste e Resultados}

Os algoritmos propostos no Capítulo 5 são aplicados a três proteínas selecionadas na literatura como exemplos de cada um dos principais domínios de proteínas. Uma proteína do domínio $\alpha$, uma do domínio $\beta$ e uma do domínio $\alpha / \beta$. As proteínas utilizadas são:

- Domínio $\alpha$ : proteína DNA/RNA ligante com código PDB 1ENH, possui 54 resíduos e é composta por três $\alpha$-hélices. Esta proteína tem como função molecular ser DNAligante;

- Domínio $\beta$ : modelo molecular do inibidor $\alpha$-amilase tendamistat com código PDB 1HOE, possui 74 resíduos e é composta por cinco fitas de folha- $\beta$. Esta proteína tem como função molecular a atividade de inibidor $\alpha$-amilase;

- Domínio $\alpha / \beta$ : proteína domínio C-terminal do ribossomo L7-L12 $50 \mathrm{~S}$ com código PDB 1CTF possui 68 resíduos e é composta por três $\alpha$-hélices e três folhas- $\beta$. Tem 
como função molecular ser uma estrutura constituinte do ribossomo.

A abordagem proposta para o problema de DEP utiliza para a predição da estrutura terciária da proteína a montagem combinatória a partir das estruturas determinadas dos polipeptídeos que compõem a proteína. Nos casos de teste, convencionou-se dividir a proteína em trechos de tamanho fixo e sem sobreposição. O tamanho dos trechos utilizado é de 20 resíduos, independente se a quebra ocorrerá no meio de uma estrutura secundária. No caso do número de resíduos da proteína não ser múltiplo de 20 admite-se um trecho com menos de 20 resíduos. Utilizando este procedimento as proteínas utilizadas tiveram a seguinte divisão:

- 1ENH foi dividida em dois polipeptídeos de tamanho 20 e um de tamanho 14. As estruturas primárias dos polipeptídeos que compõem a proteína são:

1. 1ENH_P1: RPRTAFSSEQLARLKREFNE;

2. 1ENH_P2: NRYLTERRRQQLSSELGLNE;

3. 1ENH_P3: AQIKIWFQNKRAKI.

- 1HOE foi dividida em três polipeptídeos de tamanho 20 e um de tamanho 14. Os polipeptídeos tem como estrutura primária as seguintes:

1. 1HOE_P1: DTTVSEPAPSCVTLYQSWRY;

2. 1HOE_P2: SQADNGCAETVTVKVVYEDD;

3. 1HOE_P3: TEGLCYAVAPGQITTVGDGY;

4. 1HOE_P4: IGSHGHARYLARCL.

- 1CTF foi dividida em três polipeptídeos de tamanho 20 e um de tamanho 8. As estruturas primárias dos polipeptídeos que compõem a proteína são:

1. 1CTF_P1: EFDVILKAAGANKVAVIKAV;

2. 1CTF_P2: RGATGLGLKEAKDLVESAPA;

3. 1CTF_P3: ALKEGVSKDDAEALKKALEE;

4. 1CTF_P4: AGAEVEVK.

As Seções a seguir apresentam os testes e os resultados iniciais obtidos para cada um dos AEs propostos para a predição da estrutura terciária das proteínas. Na Seção 6.2.1 são abordados e analisados os testes realizados para o AE mono-objetivo. A Seção 6.2.3 


\begin{tabular}{||c||c|c|c|c||}
\hline \hline Cod. PDB & $\begin{array}{c}\text { DME } \\
\text { Médio }\end{array}$ & $\begin{array}{c}\text { DME } \\
\text { Mínimo }\end{array}$ & $\begin{array}{c}\text { Desvio } \\
\text { Padrão } \\
\text { DME }\end{array}$ & $\begin{array}{c}\text { Mediana } \\
\text { DME }\end{array}$ \\
\hline \hline 1ENH_P1 & 6,20 & 5,22 & 0,58 & 6,32 \\
\hline 1ENH_P2 & 3,71 & 2,63 & 0,73 & 3,71 \\
\hline 1ENH_P3 & 2,96 & 1,74 & 0,68 & 3,11 \\
\hline \hline 1HOE_P1 & 5,82 & 4,63 & 0,76 & 5,73 \\
\hline 1HOE_P2 & 3,34 & 1,78 & 1,03 & 3,3 \\
\hline 1HOE_P3 & 2,74 & 2,03 & 0,35 & 2,8 \\
\hline 1HOE_P4 & 6,07 & 3,27 & 1,34 & 6,90 \\
\hline \hline 1CTF_P1 & 6,11 & 4,69 & 0,81 & 6,11 \\
\hline 1CTF_P2 & 4,45 & 3,68 & 0,72 & 4,45 \\
\hline 1CTF_P3 & 3,82 & 3,04 & 0,64 & 3,71 \\
\hline 1CTF_P4 & 5,54 & 4,51 & 0,58 & 5,91 \\
\hline \hline
\end{tabular}

Tabela 6.1: DME das estruturas dos polipeptídeos das proteínas selecionadas.

apresenta os testes para o AE multi-objetivo e a análise dos resultados obtidos. As Seções 6.2.4 e 6.2.2 apresentam os testes e resultados relativos ao AE combinatório com suas diferentes entradas, bem como a análise dos resultados.

\subsubsection{Testes e Resultados do AE Mono-Objetivo}

O AE mono-objetivo foi aplicado para a modelagem das estruturas terciárias dos polipeptídeos que compõem cada uma das proteínas alvo selecionadas. Foram efetudas diversas execuções utilizando diferentes tamanhos para os comprimentos máximos de distância (ver Seções 5.4.6 e 5.4.7) para o cálculo das energias potenciais eletrostática e de van der Waals. Os comprimentos de distância máxima investigados foram de:

- $8 \AA$ para ambas as funções de energia;

- $13 \AA$ para ambas as energias;

- $13 \AA$ para a energia eletrostática e $8 \AA$ para a energia de van der Waals.

Como não houve grandes diferenças nos valores de $D M E$ para os resultados obtidos com os diferentes comprimentos de distância serão apresentados e discutidos os resultados obtidos para as distâncias em $8 \AA$ e $13 \AA$. Durante as execuções com os diferentes comprimentos de distância máxima é observado que, quanto maior a distância maior é o gasto computacional para executar os cálculos das energias. Visto que a distância máxima determina se a interação entre os átomos será calculada ou não, ao aumentarmos o 
valor da distância, mais interações serão calculadas sem oferecer grandes constribuições ao valor da energia, pois quanto maior a distância, menor a energia da interação (ver Seções 5.4.6 e 5.4.7).

A Tabela 6.1 apresenta os valores de $D M E$ mínimo, médio, mediana e desvio padrão da estruturas obtidas para os polipeptídeos das proteínas. Observa-se que houve pouca variação dos valores de $D M E$ dos casos de teste efetuados.

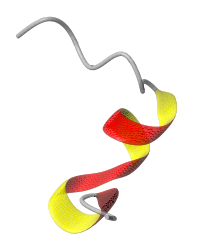

(a) Estrutura predita do polipeptídeo $1-1 \mathrm{ENH}$.

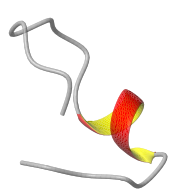

(c) Estrutura predita do polipeptídeo 2 $-1 \mathrm{ENH}$.

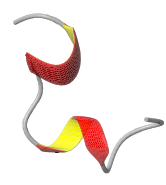

(e) Estrutura predita do polipeptídeo 3 $-1 \mathrm{ENH}$.

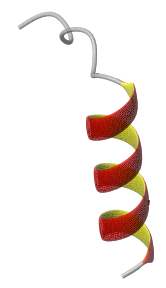

(b) Estrutura real do polipeptídeo 1 $1 \mathrm{ENH}$.

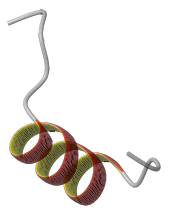

(d) Estrutura real do polipeptídeo 2 $1 \mathrm{ENH}$.

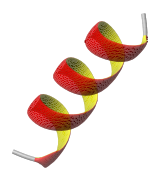

(f) Estrutura real do polipeptídeo 3 $1 \mathrm{ENH}$.

Figura 6.1: Estruturas dos polipeptídeos da proteína 1ENH.

A Figura 6.1 apresenta as estruturas com DME mínimo para os polipeptídeos da proteína 1ENH e as estruturas terciárias nativas obtidas por cristalografia de raio-X para cada um dos polipeptídeos. As estruturas nativas dos polipeptídeos foram extraídas da estrutura nativa da proteína. Na Figura 6.1(a) observa-se que a estrutura predita para o 


\begin{tabular}{||c||c|c|c|c||}
\hline \hline Cod. PDB & $\begin{array}{c}\text { Fitness } \\
\text { Médio }\end{array}$ & $\begin{array}{c}\text { Fitness } \\
\text { Mínimo }\end{array}$ & $\begin{array}{c}\text { Desvio Padrão } \\
\text { Fitness }\end{array}$ & $\begin{array}{c}\text { Mediana } \\
\text { Fitness }\end{array}$ \\
\hline \hline 1ENH_P1 & $-1052,31$ & $-1188,32$ & 97,05 & $-1051,30$ \\
\hline 1ENH_P2 & $-1265,22$ & $-1389,97$ & 114,34 & $-1193,63$ \\
\hline 1ENH_P3 & $-243,97$ & $-323,25$ & 38,28 & $-239,10$ \\
\hline \hline 1HOE_P1 & $-292,32$ & $-350,29$ & 49,09 & $-304,33$ \\
\hline 1HOE_P2 & $-273,76$ & $-375,10$ & 62,64 & $-278,98$ \\
\hline 1HOE_P3 & $-47,77$ & $-125,96$ & 40,06 & $-40,13$ \\
\hline 1HOE_P4 & $-487,73$ & $-581,56$ & 63,18 & $-455,07$ \\
\hline \hline 1CTF_P1 & $-161,12$ & $-216,08$ & 36,10 & $-146,78$ \\
\hline 1CTF_P2 & $-473,38$ & $-593,33$ & 82,04 & $-478,38$ \\
\hline 1CTF_P3 & $-564,91$ & $-644,12$ & 38,14 & $-557,05$ \\
\hline 1CTF_P4 & $-240,42$ & $-301,56$ & 29,58 & $-234,51$ \\
\hline \hline
\end{tabular}

Tabela 6.2: Função de avaliação do melhor indivíduo representando as estruturas dos polipeptídeos das proteínas selecionadas.

polipeptídeo 1 e sua estrutura nativa na Figura 6.1(b). Nota-se que na estrutura predita pelo AE ocorre a formação de uma $\alpha$-hélice que em relação a estrutura nativa possui um erro de torção na primeira volta da hélice. A estrutura predita e nativa do polipeptídeo 2 podem ser vistas nas Figuras 6.1(c) e 6.1(d) respectivamente. Observa-se na estrutura predita o início da formação de uma $\alpha$-hélice similar a da estrutura nativa, porém só com uma volta e uma tendência a formar a segunda volta. E as Figuras 6.1(e) e 6.1(f) apresentam a estrutura predita e a estrutura nativa para o polipeptídeo 3. Na estrutura predita observa-se a formação inicial de duas $\alpha$-hélices e uma tendência em formar uma terceira $\alpha$-hélice entre as duas primeiras que formaria uma $\alpha$-hélice semelhante a da estrutura nativa.

A Tabela 6.2 apresenta os valores de fitness (somatório das funções de energia) para o melhor indivíduo da população final do AE, os valores da média de fitness nas diferentes execuções do algoritmo, o valor mínimo, a mediana e o desvio padrão. Os valores de fitness mostram que os polipeptídeos possuem uma energia potencial relativamente baixa, a qual demonstra que as estruturas obtidas tendem a ser estáveis.

A Figura 6.2 apresenta a curva de convergência para a execução que obteve o menor valor de fitness de cada um dos polipeptídeos da proteína 1ENH. Observa-se que para todos os polipeptídeos, o AE teve uma queda acentuada no valor de fitness e após a queda houve uma tendência de estabilização no valor de fitness indicando que o AE não produzirá grande mudanças no valor do fitness. 


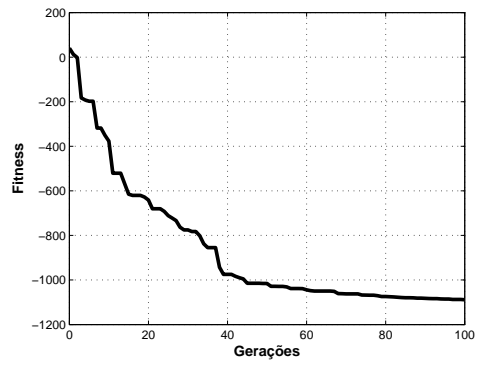

(a) Peptídeo 1 - 1ENH.

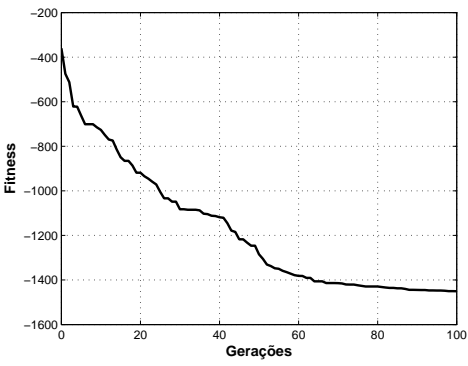

(b) Peptídeo 2 - 1ENH.

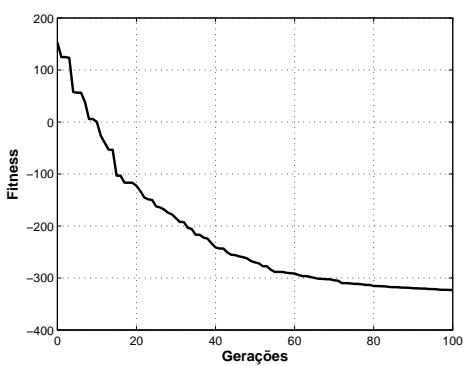

(c) Peptídeo 3 - 1ENH.

Figura 6.2: Convergência do AE para o melhor indivíduo dos polipeptídeos da 1ENH.

\begin{tabular}{||c||c|c|c|c||}
\hline \hline Cod. PDB & $\begin{array}{c}\text { DME } \\
\text { Médio }\end{array}$ & $\begin{array}{c}\text { DME } \\
\text { Mínimo }\end{array}$ & $\begin{array}{c}\text { Desvio } \\
\text { Padrão } \\
\text { DME }\end{array}$ & $\begin{array}{c}\text { Mediana } \\
\text { DME }\end{array}$ \\
\hline \hline 1ENH & 8,13 & 5,99 & 1,71 & 8,14 \\
\hline $1 \mathrm{HOE}$ & 9,23 & 7,98 & 1,19 & 8,81 \\
\hline $1 \mathrm{CTF}$ & 8,52 & 6,08 & 1,91 & 7,88 \\
\hline \hline
\end{tabular}

Tabela 6.3: DME das estruturas das proteínas selecionadas.

Além dos testes efetuados para os polipeptídeos das proteínas, o AE mono-objetivo proposto foi aplicado para a proteína completa a fim de avaliar seu desempenho e comparar com os resultados obtidos para o AE combinatório. A distância máxima pertimitida nas funções de energia eletrostática e de van der Waals foi a mesma utilizada para os testes dos polipeptídeos. A Tabela 6.3 apresenta os valores de DME mínimo, médio, mediana e desvio padrão da estruturas obtidas para as proteínas.

A Figura 6.3 apresenta a estrutura terciária predita com $D M E$ médio para a proteína $1 \mathrm{CTF}$ e a estrutura terciária nativa obtida por cristalografia de raio-X da proteína. Na Figura 6.3(a) pode ser observada na estrutura predita a formação inicial de três $\alpha$-hélices e uma tendência em formar folhas- $\beta$ na parte central da estrutura. 


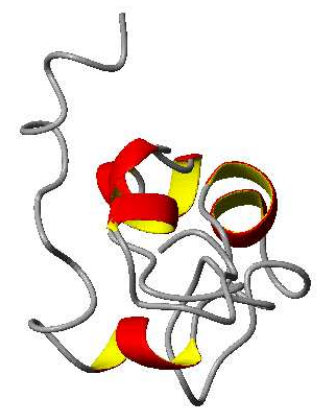

(a) Estrutura Predita.

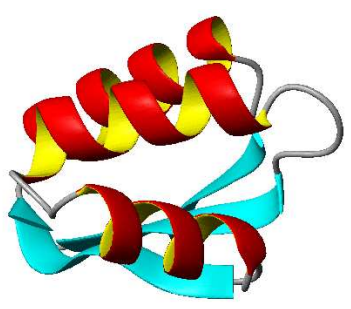

(b) Estrutura Nativa.

Figura 6.3: Estruturas terciárias da proteína 1CTF.

\begin{tabular}{||c||c|c|c|c||}
\hline \hline Cod. PDB & $\begin{array}{c}\text { Fitness } \\
\text { Médio }\end{array}$ & $\begin{array}{c}\text { Fitness } \\
\text { Mínimo }\end{array}$ & $\begin{array}{c}\text { Desvio Padrão } \\
\text { Fitness }\end{array}$ & $\begin{array}{c}\text { Mediana } \\
\text { Fitness }\end{array}$ \\
\hline \hline 1ENH & $-2263,07$ & $-2554,93$ & 224,35 & $-2241,24$ \\
\hline 1HOE & $-493,29$ & $-739,48$ & 177,64 & $-515,00$ \\
\hline 1CTF & $-818,11$ & $-1003,60$ & 118,14 & $-792,30$ \\
\hline \hline
\end{tabular}

Tabela 6.4: Fitness do melhor indivíduo representando as estruturas das proteínas selecionadas.

A Tabela 6.4 apresenta os valores de fitness para o melhor indivíduo da população final do AE contendo a média, menor valor, desvio padrão e mediana dos testes realizados. Os valores de fitness mostram que as estruturas das proteínas possuem uma energia potencial relativamente baixa, a qual demonstra que as estruturas obtidas tendem a ser estáveis. Além disso, observa-se, a partir dos resultados apresentados nas Tabelas 6.1, 6.2, 6.3 e 6.4, que não existe uma grande dispersão dos dados, concluindo que o $\mathrm{AE}$ desenvolvido não possui uma grande variância entre as diferentes execuções.

A Figura 6.4 apresenta a curva de convergência para a execução de menor fitness da proteína 1CTF. Observa-se que o AE teve uma queda acentuada no valor de fitness e após a queda houve uma tendência em estabilizar o valor da fitness indicando que o AE chegou próximo de um valor mínimo para o fitness.

Observa-se com base nos resultados obtidos a dificuldade no AE mono-objetivo em prever a formação de folhas- $\beta$. A dificuldade encontrada na predição de estruturas dessa natureza era esperado, uma vez que trabalhos semelhantes, como o de Cui (Cui et al., 1998), apresentaram a mesma dificuldade, ou até mesmo, não aplicam os algoritmos propostos a estruturas do domínio $\beta$ justificando que esse tipo de estrutura representa um caso muito complexo no problema de predição. 


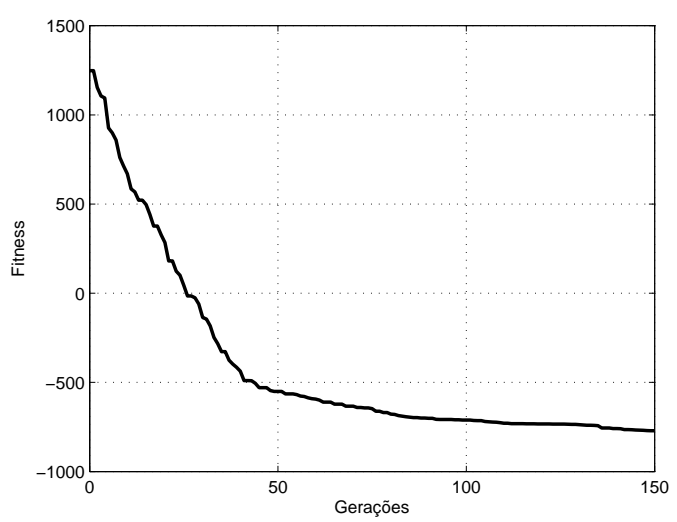

Figura 6.4: Convergência do AE para o melhor indivíduo da proteína 1CTF.

\subsubsection{Testes e Resultados do AE Combinatório com Saídas do AE Mono-Objetivo}

O AE combinatório foi testado com diferentes conjuntos de entrada obtidos da combinação das populações finais de cada execução do AE mono-objetivo para cada um dos polipeptídeos que formam as proteínas selecionadas para teste. Nos testes são consideradas somente combinações das saídas obtidas da execução do AE mono-objetivo com um mesmo valor de distância máxima permitida para as energias eletrostática e de van der Waals, ou seja, por exemplo somente as populações finais obtidas com distância máxima em $8 \AA$ e $13 \AA$ podem ser combinadas para gerar a população inicial do AE combinatório. No AE combinatório utilizou-se durantes os testes a distância máxima permitida para a energia da van der Waals em $8 \AA$ e para energia eletrostática em $13 \AA$.

A Tabela 6.5 apresenta os resultados obtidos das execuções do AE combinatório utilizando as saídas do AE mono-objetivo com a distância máxima considerada para cálculo das interações eletrostáticas e de van der Waals em $13 \AA$ e $8 \AA$ respectivamente. Os testes efetuados com as saídas do AE mono-objetivo utilizando os outros valores limitantes de distância máxima não serão apresentados pois não houve melhora significativa no desempenho do AE combinatório. Na Tabela 6.5 são apresentados os valores de $D M E$ médio, mínimo, desvio padrão e mediana das diversas execuções efetuadas com as diferentes combinações de saídas do AE mono-objetivo para o AE combinatório.

A Figura 6.5 apresenta a estrutura nativa e a estrutura predita com menor valor de $D M E$ da proteína 1ENH. Observa-se que a estrutura predita apresentada na Figura 6.5(a) apesar de possuir um $D M E$ baixo, possue uma similaridade visual pequena com a proteína real (ver Figura 6.5(b)). Por outro lado, observa-se em algumas partes a tendência em 


\begin{tabular}{||c||c|c|c|c||}
\hline \hline Cod. PDB & $\begin{array}{c}\text { DME } \\
\text { Médio }\end{array}$ & $\begin{array}{c}\text { DME } \\
\text { Mínimo }\end{array}$ & $\begin{array}{c}\text { Desvio } \\
\text { Padrão } \\
\text { DME }\end{array}$ & $\begin{array}{c}\text { Mediana } \\
\text { DME }\end{array}$ \\
\hline \hline 1ENH & 14,01 & 10,21 & 2,47 & 13,6 \\
\hline 1HOE & 21,19 & 13,17 & 4,94 & 20,64 \\
\hline 1CTF & 20,83 & 15,84 & 2,60 & 20,92 \\
\hline \hline
\end{tabular}

Tabela 6.5: DME das estruturas das proteínas selecionadas obtidos com o AE combinatório.

\begin{tabular}{||c||c|c|c|c||}
\hline \hline Cod. PDB & $\begin{array}{c}\text { Fitness } \\
\text { Médio }\end{array}$ & $\begin{array}{c}\text { Fitness } \\
\text { Mínimo }\end{array}$ & $\begin{array}{c}\text { Desvio Padrão } \\
\text { Fitness }\end{array}$ & $\begin{array}{c}\text { Mediana } \\
\text { Fitness }\end{array}$ \\
\hline \hline 1ENH & $-1224,52$ & $-1367,97$ & 132,35 & $-1256,36$ \\
\hline 1HOE & 388,87 & 134,19 & 144,25 & 372,91 \\
\hline 1CTF & 3,24 & $-132,86$ & 93,48 & 38,04 \\
\hline \hline
\end{tabular}

Tabela 6.6: Fitness do melhor indivíduo representando as estruturas das proteínas selecionadas para o AE combinatório.

formar a estrutura correspondente na estrutura nativa.

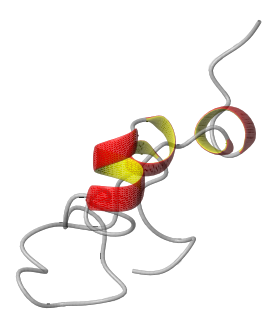

(a) Estrutura Predita.

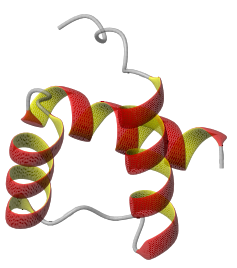

(b) Estrutura Nativa.

Figura 6.5: Estruturas terciárias da proteína 1ENH.

A convergência do AE combinatório pode ser vista na Figura 6.6 que mostra a execução desse para a proteína 1ENH que obteve o melhor valor de fitness das execuções realizadas durantes os testes. Observa-se que há uma grande queda no valor da fitness e após essa a função estabiliza não havendo grandes mudanças no valor da fitness. A Tabela 6.6 apresenta os valores de fitness obtidos para os testes efetuados trazendo a média, menor fitness, desvio padrão e a mediana. Analisando as Tabelas 6.5 e 6.6 nota-se que o AE combinatório, assim como o AE mono-objetivo, não apresenta uma grande dispersão dos 
resultados de uma execução em relação a outra pois a média e a mediana dos resultados possuem valores próximos, isto mostra que o AE possue tende a prever resultados similares nas diversas execuções.

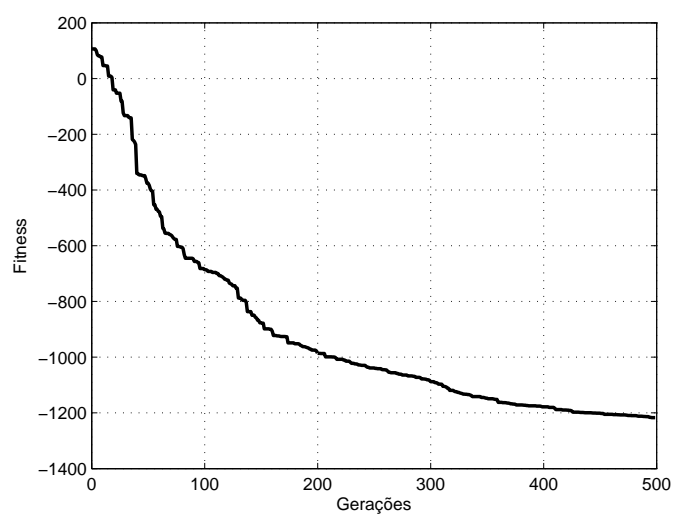

Figura 6.6: Convergência do AE para o melhor indivíduo da proteína 1ENH.

\subsubsection{Testes e Resultados do AE Multi-Objetivo}

Além dos testes efetuados para predição da estrutura terciária dos polipeptídeos que foram as proteínas alvo com o AE mono-objetivo também foram realizados testes utilizando a abordagem com o AE multi-objetivo. As distância máximas para calcular as energias de van der Waals e eletrostática consideradas para o AE multi-objetivo foram as mesmas do AE mono-objetivo. Os resultados apresentados são referentes aos testes efetuados com distâncias máximas em $8 \AA$ e $13 \AA$ para as energias de van der Waals e eletrostática respectivamente.

Para os cálculos de $D M E$ dos resultados apresentados pelo AE multi-objetivo foram selecionados alguns indivíduos da população final do algoritmo que representa a fronteira de Pareto. Para os indivíduos selecionados obteve-se a estrutura terciária que cada um deles representa e foi então calculado o $D M E$ de cada uma das estruturas terciárias obtidas em relação a estrutura nativa.

A Tabela 6.7 apresenta os valores de DME mínimo, médio, mediana e desvio padrão da estruturas terciárias obtidas para os polipeptídeos das proteínas para uma das populações obtidas das execuções do AE multi-objetivo.

A Figura 6.7 apresenta as estruturas com DME mínimo para os polipeptídeos da proteína $1 \mathrm{HOE}$ de um dos indivíduos aleatoriamente selecionadas da população final de uma das execuções do AE multi-objetivo e as estruturas terciárias nativas obtidas da estrutura nativa da proteína completa determinada por cristalografia de raio-X. Observa-se que 


\begin{tabular}{||c||c|c|c|c||}
\hline \hline Cod. PDB & $\begin{array}{c}\text { DME } \\
\text { Médio }\end{array}$ & $\begin{array}{c}\text { DME } \\
\text { Mínimo }\end{array}$ & $\begin{array}{c}\text { Desvio } \\
\text { Padrão } \\
\text { DME }\end{array}$ & $\begin{array}{c}\text { Mediana } \\
\text { DME }\end{array}$ \\
\hline \hline 1ENH_P1 & 6,04 & 4,04 & 1,45 & 6,22 \\
\hline 1ENH_P2 & 4,26 & 3,56 & 0,66 & 3,99 \\
\hline 1ENH_P3 & 2,94 & 1,67 & 0,84 & 2,96 \\
\hline \hline 1HOE_P1 & 5,46 & 2,50 & 1,31 & 5,66 \\
\hline 1HOE_P2 & 3,39 & 1,64 & 0,66 & 3,38 \\
\hline 1HOE_P3 & 1,35 & 0,32 & 0,57 & 1,66 \\
\hline 1HOE_P4 & 4,66 & 2,44 & 1,20 & 4,60 \\
\hline \hline 1CTF_P1 & 7,27 & 4,48 & 1,61 & 8,10 \\
\hline 1CTF_P2 & 3,76 & 2,58 & 1,18 & 3,22 \\
\hline 1CTF_P3 & 4,17 & 3,19 & 0,92 & 3,83 \\
\hline 1CTF_P4 & 5,32 & 3,17 & 0,98 & 5,76 \\
\hline \hline
\end{tabular}

Tabela 6.7: DME das estruturas dos polipeptídeos das proteínas selecionadas obtidas pelo AE multi-objetivo.

tanto para a estrutura predita quanto para a estrutura nativa dos polipeptídeos o software utilizado para visualizar as estruturas não conseguiu determinar a formação das folhas3. A Figura 6.7(a) apresenta a estrutura predita do polipeptídeo 1 da proteína 1HOE onde observa-se uma pequena semelhança na parte superior da estrutura com a estrutura nativa do polipeptídeo na Figura 6.7(b). A estrutura predita e nativa do polipeptídeo 2 podem ser observadas nas Figuras 6.7(c) e 6.7(d), respectivamente. Nas Figuras 6.7(e) e 6.7(f) são observadas a estrutura terciária predita e a estrutura terciária nativa para o polipeptídeo 3 da proteína 1HOE. E nas Figuras $6.7(\mathrm{~g})$ e $6.7(\mathrm{~h})$ são apresentadas as estruturas predita e nativa do polipeptídeo 4. Esses polipeptídeos representam estruturas do tipo folha- $\beta$ que são formadas pela interação entre muitos resíduos distantes, o que pelo processo de determinação da estrutura em pedaços foi um pouco prejudicado dificultando o processo dos AEs, tanto mono-objetivo quanto multi-objetivo.

Na Figura 6.8 pode ser vista a fronteira de Pareto obtida no AE multi-objetivo para o primeiro polipeptídeo da proteína $1 \mathrm{HOE}$, onde o eixo-X representa o objetivo composto pela energia de van der Waals, o eixo-Y representa a energia eletrostática e o eixo-Z representa o objetivo composto pelas energias associadas aos atómos ligados, denominadas energias de ligação. As cores dos indivíduos é determina pelo valor da energia eletróstática, onde as cores mais escuras indicam indivíduos com valor mais baixo e as cores mais claras valores mais altos, cada cor representa uma faixa de valores da energia eletrostática. Esta escala de cores é utilizada em todos os gráficos apresentados independente da energia 


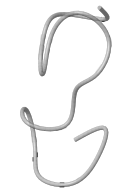

(a) Estrutura predita do polipeptídeo 1 - 1HOE.

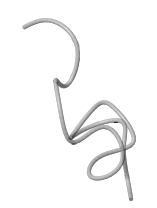

(c) Estrutura predita do polipeptídeo 2 - 1HOE.

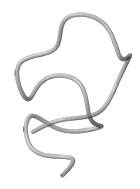

(e) Estrutura predita do polipeptídeo 3 - 1HOE.

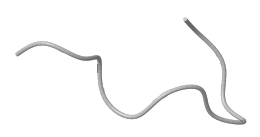

(g) Estrutura predita do polipeptídeo 4 - 1HOE.

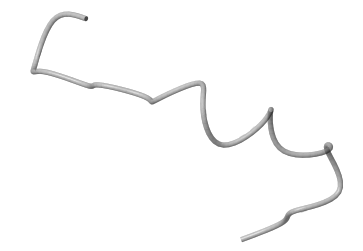

(b) Estrutura real do polipeptídeo 1 - 1HOE.

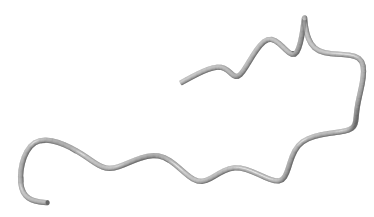

(d) Estrutura real do polipeptídeo 2 - 1HOE.

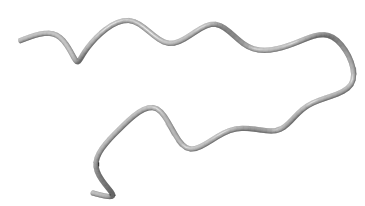

(f) Estrutura real do polipeptídeo 3 - 1HOE.

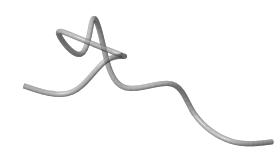

(h) Estrutura real do polipeptídeo 4 - $1 \mathrm{HOE}$.

Figura 6.7: Estruturas dos polipeptídeos da proteína 1HOE.

escolhida para determinar a cor. Observa-se que os indivíduos que representam a fronteira de Pareto formam um superfície que lembra o formato de uma bacia. Também pode ser observado que indivíduos com energia eletrostática mais baixa possuem a tendência de possuir energia de van der Waals e energias de ligação mais altas, e que ao diminuir-se 
muito as energias de van der Waals e de ligação tende-se a aumentar o valor da energia eletrostática, isto comprova o comportamento esperado dessas funções visto na seção 5.4.

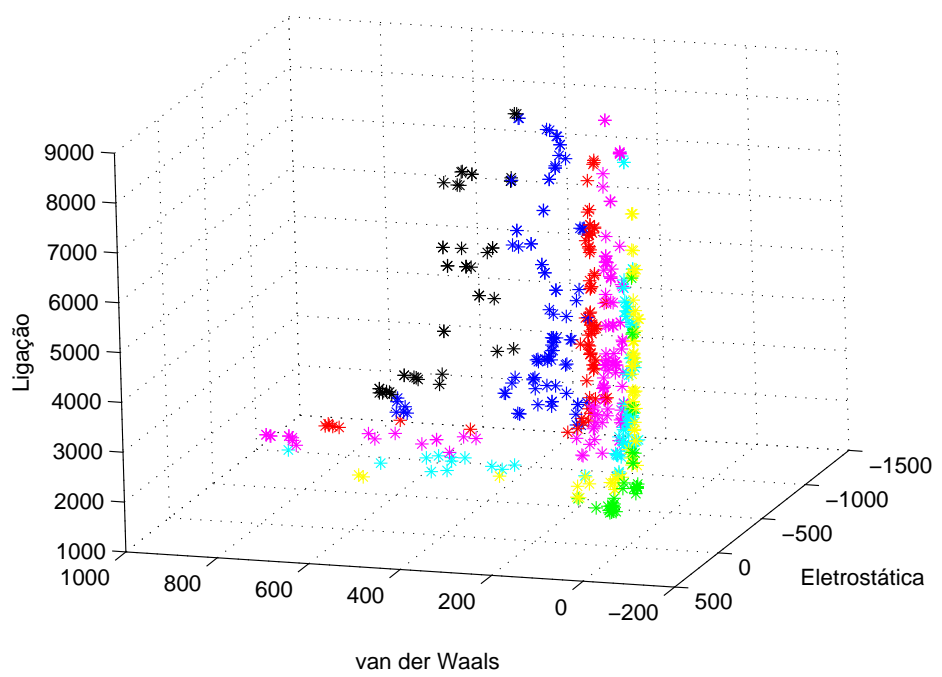

Figura 6.8: Fronteira de Pareto do primeiro polipeptídeo da proteína 1HOE.

A Figura 6.9 apresenta a distribuição dos indivíduos da fronteira de pareto com os três objetivos combinados dois a dois. Na Figura 6.9(a) observa-se a divisão dos indivíduos nos objetivos energia de van der Waals e energias de ligação onde a cor dos invidíduos é determinada pela energia eletrostática. Observando esta Figura fica bem claro evidenciase novamente que, quando se diminue as energias de van der Waals e de ligação, a energia eletróstática aumenta. A Figura 6.9(b) apresenta a distribuição dos indivíduos pelos objetivos de energia de van der Waals e energia eletrostática, as energias de ligação indicam a cor do indivíduo. Observa-se nesta Figura a formação de uma fronteira de pareto bem definida minimizando os dois objetivos e que os indivíduos da fronteira possuem energia de ligação mais alta do que os demais indivíduos. E na Figura 6.9(c) tem-se a distribuição dos indivíduos pelos objetivos energias de ligação e energia eletrostática, sendo a cor determinada pela energia de van der Waals. Observa-se a tendência de formar uma fronteira de pareto na região de minimização dos dois objetivos, mas que os indivíduos estão bem distribuídos e que, na região onde ocorre a minimização dos dois objetivos, o terceiro objetivo tende a ter um valor maior.

Além dos testes efetuados para os polipeptídeos das proteínas o AE multi-objetivo foi aplicado para predizer a estrutura terciária da proteína completa a fim de avaliar seu desempenho. A distância máxima permitida nas funções de energia eletrostática e de van 


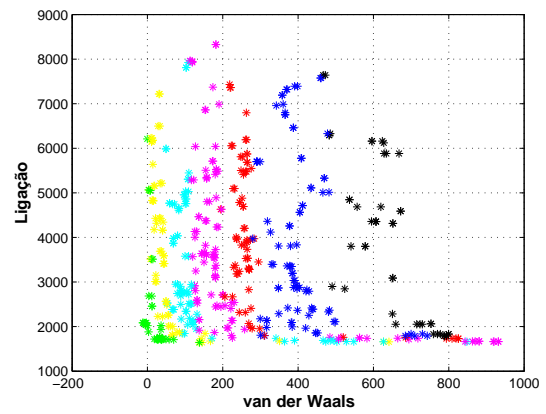

(a) Objetivos 1 e 2 .

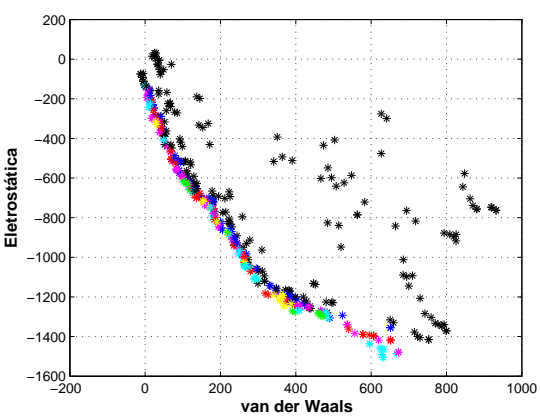

(b) Objetivos 1 e 3 .

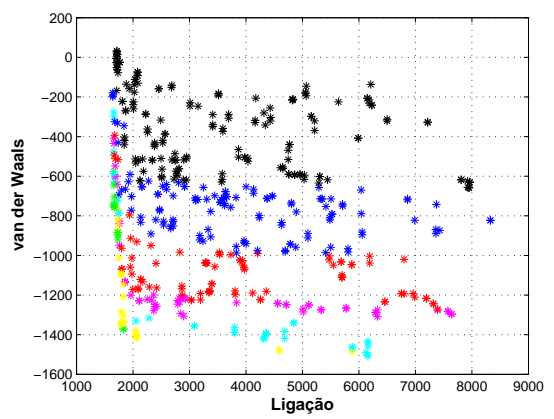

(c) Objetivos 2 e 3 .

Figura 6.9: Distribuição dos indivíduos na fronteira de Pareto dividos em 2 objetivos para o primeiro polipeptídeo da proteína 1HOE.

der Waals é a mesma utilizada para os testes dos polipeptídeos.

A Tabela 6.8 apresenta os valores de DME mínimo, médio, mediana e desvio padrão das estruturas obtidas para as proteínas de alguns indivíduos selecionados de uma execução do AE multi-objetivo.

A Figura 6.10 apresenta a estrutura com DME mínimo para a proteína $1 \mathrm{HOE}$ dos indivíduos selecionadas da população final de AE multi-objetivo que formam a fronteira de Pareto e a estrutura terciária nativa obtida por cristalografia de raio-X da proteína. Na Figura 6.10(a) apresenta a estrutura predita da proteína 1HOE onde pode ser observada

\begin{tabular}{||c||c|c|c|c||}
\hline \hline Cod. PDB & $\begin{array}{c}\text { DME } \\
\text { Médio }\end{array}$ & $\begin{array}{c}\text { DME } \\
\text { Mínimo }\end{array}$ & $\begin{array}{c}\text { Desvio } \\
\text { Padrão } \\
\text { DME }\end{array}$ & $\begin{array}{c}\text { Mediana } \\
\text { DME }\end{array}$ \\
\hline \hline 1ENH & 9,50 & 6,51 & 3,00 & 7,82 \\
\hline 1HOE & 11,38 & 8,11 & 3,28 & 10,49 \\
\hline 1CTF & 10,28 & 7,32 & 3,02 & 9,57 \\
\hline \hline
\end{tabular}

Tabela 6.8: DME das estruturas das proteínas selecionadas. 
a formação de quatro pequenas folhas- $\beta$ e a formação inicial de uma $\alpha$-hélice, que pode ser considerado um erro do processo de predição, visto que pela estrutura nativa (ver Figura 6.10(b)) não existem $\alpha$-hélices nesta proteína. Vale ressaltar que com base nesse resultado uma melhora em relação ao AE mono-objetivo do AE multi-objetivo em prever a formação de folhas- $\beta$.

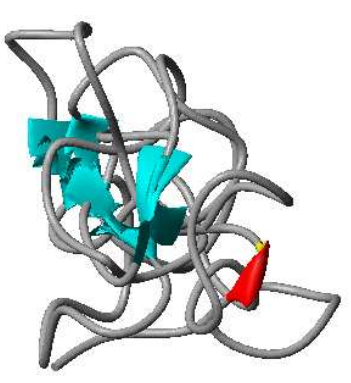

(a) Estrutura Predita.

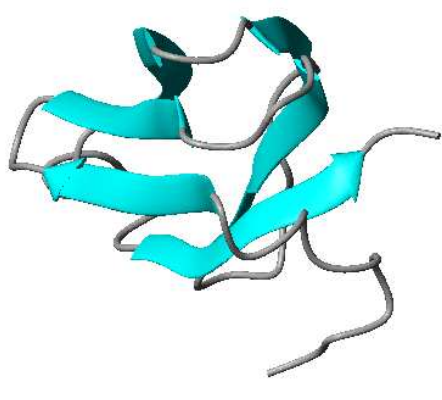

(b) Estrutura Nativa.

Figura 6.10: Estruturas terciárias da proteína 1HOE.

A Figura 6.11 apresenta a fronteira de Pareto para a execução da proteína 1HOE onde o eixo-X representa o objetivo composto pela energia de van der Waals, o eixo-Y representa a energia eletrostática e o eixo-Z representa o objetivo composto pelas energias associadas aos atómos ligados, denominadas energias de ligação. As cores dos indivíduos é a mesma da Figura 6.8. Observa-se que os indivíduos que representam a fronteira de Pareto formam um superfície que lembra o formato de uma bacia. Também pode ser observado que indivíduos com energia eletrostática mais baixa possuem a tendência de possuir energia de van der Waals e energias de ligação mais altas, e que ao diminuir-se muito as energias de van der Waals e de ligação tende-se a aumentar o valor da energia eletrostática, reforçando o comportamento esperado dessas funções visto na seção 5.4.

A Figura 6.12 apresenta a distribuição dos indivíduos da fronteira de pareto com os três objetivos combinados dois a dois. Assim como nas Figuras 6.9(a), 6.9(b) e 6.9(c) as Figuras 6.12(a), 6.12(b) e 6.12(c) representam os mesmos objetivos e apresentam comportamentos semelhantes para as distribuições dos indivíduos em relação aos valores das energias. 


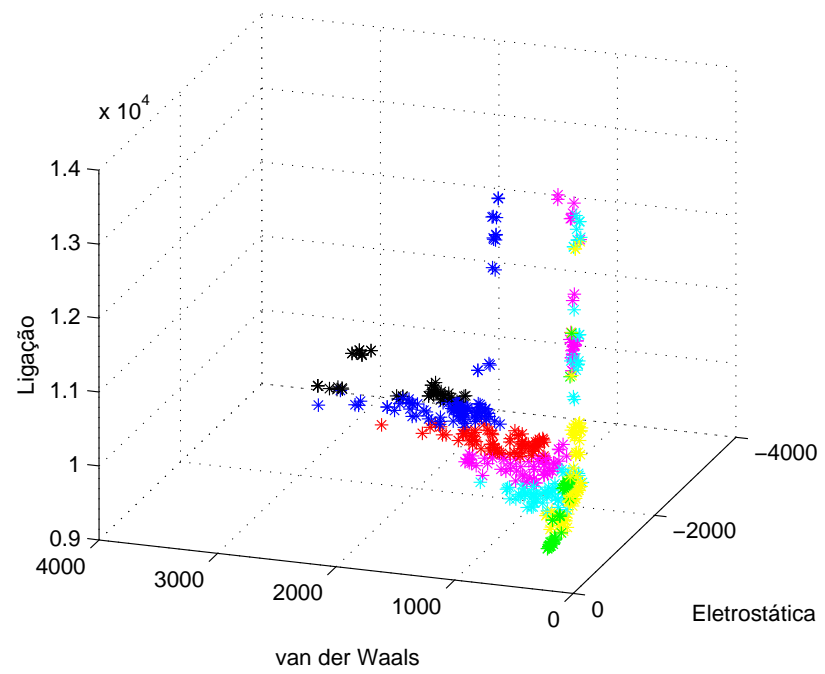

Figura 6.11: Fronteira de Pareto da proteína 1HOE.

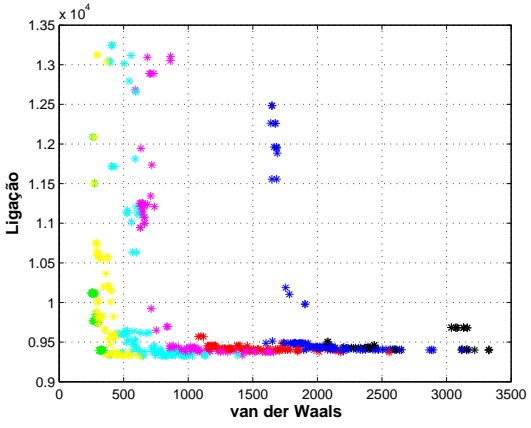

(a) Objetivos 1 e 2 .

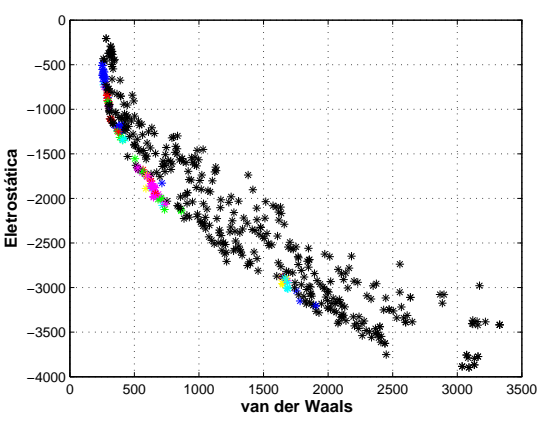

(b) Objetivos 1 e 3 .

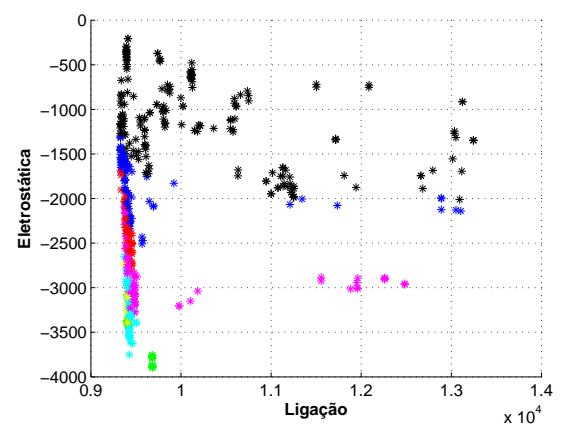

(c) Objetivos 2 e 3 .

Figura 6.12: Distribuição dos indivíduos na fronteira de Pareto dividos em 2 objetivos para a proteína $1 \mathrm{HOE}$.

\subsubsection{Testes e Resultados do AE Combinatório com Saídas do AE Multi-Objetivo}

O AE combinatório foi testado com diferentes conjuntos de entrada obtidos da combinação das populações finais de cada exectu̧̧ão do AE multi-objetivo para cada um dos 


\begin{tabular}{||c||c|c|c|c||}
\hline \hline Cod. PDB & $\begin{array}{c}\text { DME } \\
\text { Médio }\end{array}$ & $\begin{array}{c}\text { DME } \\
\text { Mínimo }\end{array}$ & $\begin{array}{c}\text { Desvio } \\
\text { Padrão } \\
\text { DME }\end{array}$ & $\begin{array}{c}\text { Mediana } \\
\text { DME }\end{array}$ \\
\hline \hline 1ENH & 12,48 & 6,39 & 5,20 & 11,48 \\
\hline 1HOE & 25,79 & 21,13 & 3,49 & 25,53 \\
\hline 1CTF & 24,37 & 23,02 & 1,24 & 24,09 \\
\hline \hline
\end{tabular}

Tabela 6.9: DME das estruturas das proteínas selecionadas obtidos com o AE combinatório.

polipeptídeos que formam as proteínas selecionadas para teste. As mesmas restrições utilizadas para os testes com as saídas do AE mono-objetivo são impostas para os testes efetuados com as saídas do AE multi-objetivo.

A Tabela 6.9 apresenta os resultados obtidos das execuções do AE combinatório utilizando as saídas do AE multi-objetivo com a distância máxima considerada para cálculo das interações eletrostáticas e de van der Waals em $13 \AA$ e $8 \AA$ respectivamente. Os testes efetuados com as saídas do AE multi-objetivo utilizando os outros valores limitantes de distância máxima não serão apresentados pois não houve melhora significativa no desempenho do AE combinatório. Na Tabela 6.9 são apresentados os valores de $D M E$ médio, mínimo, desvio padrão e mediana das diversas execuções efetuadas com as diferentes combinações de saídas do AE multi-objetivo para o AE combinatório.

A Figura 6.13 apresenta a estrutura nativa e a estrutura predita com menor valor de $D M E$ da proteína 1ENH. Observa-se que a estrutura predita apresentada na Figura 6.13(a) apesar de possuir um DME baixo possue uma similaridade visual pequena com a proteína real (ver Figura 6.5(b)), porém observa-se em algumas partes a tendência em formar a estrutura correspondente na estrutura nativa. Por conter uma maior diversidade de estruturas nas saídas do AE multi-objetivo os testes do AE combinatório utilizando-as apresentam resultados melhores do que os testes com as saídas do AE mono - objetivo. A convergência do AE combinatório pode ser vista na Figura 6.14 que mostra a execução desse para a proteína 1ENH que obteve o melhor valor da fitness das execuções realizadas durantes os testes. Pode-se observar pelo gráfico de convergência apresentado que o AE combinatório convergiu para um valor de energia potencial baixo porém o resultado ainda pode ser refinado.

A Tabela 6.10 apresenta os valores da função de avalição obtidos para os testes efetuados apresentando a média, menor fitness, desvio padrão e a mediana. Analisando as Tabelas 6.9 e 6.10, nota-se que o AE combinatório, assim como os AEs mono-objetivo, multi-objetivo e combinatório com as saídas do mono-objetivo, não apresenta uma grande 


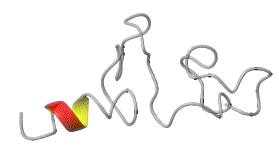

(a) Estrutura Predita.

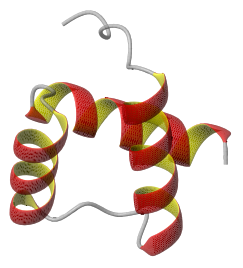

(b) Estrutura Nativa.

Figura 6.13: Estruturas terciárias da proteína 1ENH.

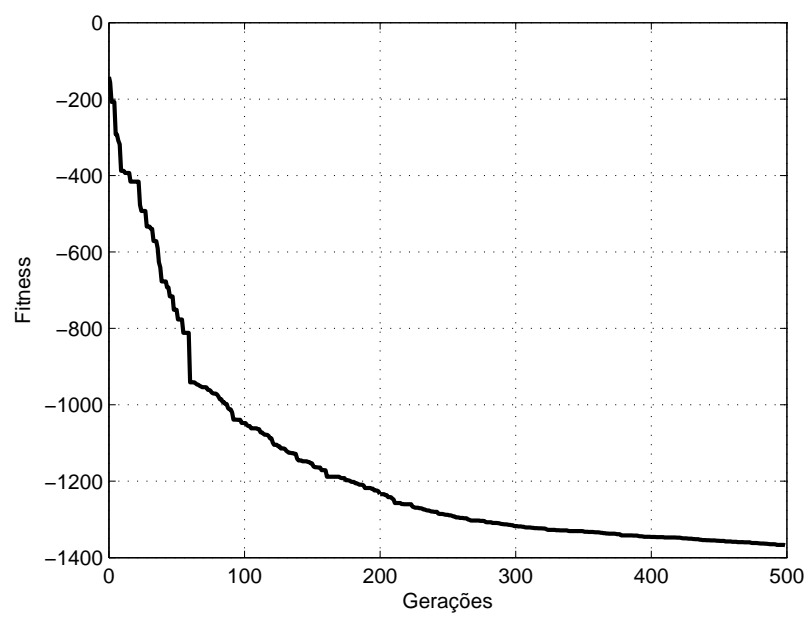

Figura 6.14: Convergência do AE para o melhor indivíduo da proteína 1ENH.

dispersão dos resultados de uma execução em relação a outra pois a média e a mediana dos resultados possuem valores próximos mostrando que os AEs propostos possuem a tendência de prever resultados similares nas diversas execuções. 


\begin{tabular}{||c||c|c|c|c||}
\hline \hline Cod. PDB & $\begin{array}{c}\text { Fitness } \\
\text { Médio }\end{array}$ & $\begin{array}{c}\text { Fitness } \\
\text { Mínimo }\end{array}$ & $\begin{array}{c}\text { Desvio Padrão } \\
\text { Fitness }\end{array}$ & $\begin{array}{c}\text { Mediana } \\
\text { Fitness }\end{array}$ \\
\hline \hline 1ENH & $-1136,17$ & $-1367,85$ & 147,01 & $-1108,55$ \\
\hline 1HOE & 1297,38 & 1085,85 & 239,46 & 1199,73 \\
\hline $1 \mathrm{CTF}$ & 99,29 & $-86,66$ & 170,59 & 66,16 \\
\hline \hline
\end{tabular}

Tabela 6.10: Função de avaliação do melhor indivíduo representando as estruturas das proteínas selecionadas para o AE combinatório. 


\section{Capítulo}

7

\section{Conclusões}

Este trabalho propõem a investigação de uma abordagem utilizando AEs para o problema de DEP. Neste trabalho, desenvolveram-se e analizaram-se um AE mono-objetivo e um AE multi-objetivo para DEP. Além disso, foi proposta e avaliada outra abordagem que consiste na aplicação de AEs mono-objetivo e multi-objetivo para a predição da estrutura dos polipeptídeos que formam uma proteína e da combinação da estrutura obtida para cada um dos polipeptídeos por um outro AE obtendo a estrutura terciária da proteína.

Os resultados da aplicação dos AEs propostos mostraram que as abordagens investigadas possuem potencial preditivo da estrutura terciária das proteínas. Entretanto, os resultados também indicam que o problema de DEP ainda não pode ser solucionado com uma precisão elevada pela abordagem investigada neste trabalho. Os AEs mono-objetivo e multi-objetivo conseguem prever com certa precisão a estrutura terciária dos polipeptídeos, necessitando de alguns ajustes para melhorar a predição de estruturas de folha- $\beta$, tendo sido adequados para prever as $\alpha$-hélices. O AE combinatório apresentou resultados pouco satisfatórios, sendo a abordagem que necessita de maiores ajustes. Uma justificativa para os resultados do AE combinatório é que este parte de polipeptídeos preditos com conformações diferentes das estruturas nativas.

Portanto, de um modo geral, a abordagem investigada nesta dissertação deve continuar sendo objeto de pesquisa, visto que os resultados apresentados demonstram que essa pode ser uma técnica com potencial preditivo da estrutura terciária das proteínas independente do tamanho da proteína. 


\subsection{Trabalhos Futuros}

Dentre as propostas de trabalhos futuros, sugere-se o refinamento dos AEs descritos no Capítulo 5, em especial, do AE combinatório. Um dos refinamentos sugeridos é a paralelização dos AEs propostos, na avaliação dos indivíduos, com populações evoluindo paralelamente com a aplicação do operador de migração, ou seja, com a troca de indivíduos entre as populações paralelas e a aplicação do AE para os diversos peptídeos da proteína simultâneamente. Outra proposta é a análise da convergência das AEs com a verificação do empacotamente excessivo que foi observado em alguns resultados dos testes realizados. Outro refinamento para os AEs é desenvolver novos operadores específicos para o problema de DEP para melhorar a performance dos algoritmos.

Algoritmos que auxiliem os AEs propostos neste trabalho também constituem-se em trabalhos futuros. Uma proposta é agregar aos AEs sistemas inteligentes (Fuzzy (Mamdami, 1974) e Raciocínio Baseado em Casos (RBC)(Leake, 1996),(Kolodner, 1993)) formando um sistema híbrido. Os sistemas Fuzzy seriam utilizados para manter a diversidade da população dos AES. No AE multi-objetivo o sistema Fuzzy poderia selecionar, dentre os indivíduos da fronteira de Pareto, aquele que representaria a melhor estrutura da proteína. O RBC auxiliaria os AEs propostos na formação da população inicial e na seleção dos indivíduos para reprodução e sobrevivência para a próxima geração.

Outra abordagem futura é explorar o caminho de evolução seguido pelo $\mathrm{AE}$ da população inicial até a população final obtida. A princípio, duas técnicas podem ser aplicadas na implementação dessa abordagem, RBC e Redes Neurais. Para a aplicação do RBC uma base de dados contendo os caminhos de evolução para cada execução dos AEs seria construída, então o RBC recuperaria possíveis alterações que poderiam ser aplicadas a um indivíduo em determinado estado da evolução, com o objetivo de melhorar a estrutura do invíduo. Além disso, sugere-se a análise da base de dados construída com as evoluções dos AEs com o objetivo de verificar do caminho de evolução seguido nas diversas execuções e assim obter um possível caminho de dobramento da proteína. A aplicação de Redes Neurais obteria regras de decaimento das funções de energia durante a evolução do AE, dados os valores de energia potencial dos indivíduos da população inicial e dos indivíduos da população final. 


\section{Referências Bibliográficas}

Aarts, E. and Korst, J. (1989). Simulated Annealing and Boltzmann Machines: A Stochastic Approach to Combinatorial Optimization and Neural Computing. John Wiley and Sons.

Barton, G., Cohen, P., and Bradford, D. (1993). Conservation analysis and structure prediction of the protein serine/threonine phosphatases. Eur. J. Biochem, 220:225237.

Bastolla, U., Frauenkron, H., Gerstner, E., Grassberger, P., and Nadler, W. (1998). Testing a new monte carlo algorithm for protein folding. Proteins: Structure, Function and Genetics, 32:52-66.

Baxevanis, A. and Ouellette, B. (2001). Bioinformatics - A practical guide to the analysis of genes and proteins. Lawrence Erlbaum Associates Publishers.

Blundell, T. and Mizuguchi, K. (2000). Structural genomics: an overview. Prog. Biophys. Mol. Biol., 73:289-295.

Boldt, Y., Sadowsky, M., Ellis, L., Que, L., and Wackett, L. (1995). A manganesedependent dioxygenase from arthrobacter globiforuis cm-2 belongs to the major extradiol dioxygenase family. J. Bacteriology, 177:1225-1232.

Bonneau, R. (2001). Ab initio protein structure prediction: Progress and prospects. Annual Review of Biophysics and Biomolecular Structure, 30(1):173-189.

Bowie, J. and Eisenberg, D. (1994). An evolutionary approach to folding small $\alpha$-helical proteins that uses sequence information and an empirical guiding fitness function. Proc. Natl. Acad. Sci. USA, 91:4436-4440. 
Braden, K. (2002). A simple approach to protein structure prediction using genetic algorithms.

Branden, C. and Tooze, J. (1991). Introduction to Protein Structure. Garland Publishing.

Brooks, B. et al. (1983). Charmm: A program for macromolecular energy, minimization, and dynamic calculations. Journal of Computacional Chemistry, 4:187-217.

Bäck, T. (1996). Evolutionary Algorithms in Theory and Practice. Oxford University Press.

Bäck, T., Fogel, D., and Michalewicz, Z. (1997). Handbook of Evolutionary Computation. Institute of Physics Publishing and Oxford University Press.

Campbell, D. (1956). Adaptive behavior from random response. Behavior Science, 1:105110.

Carvalho, A., Delbem, A., Simões, E., Telles, G., and Romero, R. (2004). Computação bioinspirada. In Anais XXIII Jornada de Atualização em Informárica.

Coello, C. and Pulido, G. (2001). Multiobjective optimization using a micro-genetic algorithm. In Spector, L., Goodman, E., Wu, A., Langdon, W., Voigt, H., Gen, M., Sen, S., Dorigo, M., Pezeshk, S., Garzon, M., and Burke, E., editors, Proceedings of the Genetic and Evolutionary Computation Conference (GECCO 2001), pages 274-281. Morgan Kaufmann Publishers.

Cohen, B. and Cohen, F. (1994). Predictions of protein secondary and tertiary structure. In Biocomputing: Informatics and Genome Projects, pages 203-232.

Cohen, B., Presnell, S., and Cohen, F. (1993). Origins of structural diversity within sequentially identical hexapeptides. Protein Science, 2:2134-2145.

Copeland, R. (1993). Methods for Protein Analysis - A pratical guide to laboratory protocols. M. Chapman e Hall.

Corne, D., Jerram, N., Knowles, J., and Oates, M. (2001). Pesa-ii: Region-based selection in evolutionary multiobjective optimization. In Spector, L., Goodman, E., Wu, A., Langdon, W., Voigt, H., Gen, M., Sen, S., Dorigo, M., Pezeshk, S., Garzon, M., and Burke, E., editors, Proceedings of the Genetic and Evolutionary Computation Conference (GECCO 2001), pages 283-290. Morgan Kaufmann Publishers. 
Corne, D., Knowles, J., and Oates, M. (2000). The pareto envelope-based selection algorithm for multiobjective optimization. In Deb, K., G. Rudolph, X. Y., Lutton, E., Merelo, J. J., and Schwefel, H. P., editors, Proceedings of the Parallel Problem Solving from Nature VI Conference, pages 839-848. Springer. Lecture Notes in Computer Science No. 1917.

Cui, Y., Chen, R., and Wong, W. (1998). Protein folding simulation with genetic algorithm and supersecondary structure constraints. Proteins, 31:247-257.

Cutello, V., Narzisi, G., and Nicosia, G. (2005). A multi-objective evolutionary approach to the protein structure predicition problem. J. R. Soc. Interface, 83:1-13.

Darwin, C. (1859). On the Origin of Species By Means of Natural Selection.

Davis, L. (1991). Handbook of Genetic Algorithms. Van Nostrand Reinhold.

Day, R., Zydallis, J., and Lamont, G. (2002). Solving the protein structure prediction problem through a multiobjective genetic algorithm. In Technical Proceedings of the 2002 International Conference on Computational Nanoscience and Nanotechnology, pages 32-35.

Deb, K. (2001). Multi-Objective Optimization using Evolutionary Algorithms. John Wiley and Sons, LTD.

Deb, K., Agrawal, S., Pratab, A., and Meyarivan, T. (2000). A Fast Elitist NonDominated Sorting Genetic Algorithm for Multi-Objective Optimization: NSGA-II. KanGAL report 200001, Indian Institute of Technology, Kanpur, India.

Doolittle, R. (1986). Of URFs and ORFs: A Primer on How to Analyze Derived Amino Acid Sequences. University Science Books.

Eshelman, L. and Schaffer, J. (1993). Real-coded genetic algorithms and interval schemata. In Foundations of Genetic Algorithms 2, pages 187-202.

Farmer, J., Toffoli, T., and Wolfram, S. (1983). Cellular automata. In Interdisciplinary Workshop at Los Alamos.

Fogel, D. (1994). An introduction to simulated evolutionary computation. IEEE Transactions on Neural Networks, 5:3-14.

Fogel, L. (1962). Autonomous automata. Industrial Research, 4:14-19. 
Fogel, L., Owens, A., and Walsh, M. (1966). Artificial Intelligence through Simulated Evolution. Willey and Sons.

Fonseca, C. and Fleming, P. (1993). Genetic Algorithms for Multiobjective Optimization: Formulation, Discussion and Generalization. In Forrest, S., editor, Proceedings of the Fifth International Conference on Genetic Algorithms, pages 416-423, San Mateo, California. University of Illinois at Urbana-Champaign, Morgan Kauffman Publishers.

Friedman, G. (1956). Selective Feedback Computers for Engineering Synthesis and Nervous System Analogy. PhD thesis, UCLA.

Friedman, G. (1959). Digital simulation of an evolutionary process. General Systems: Yearbook of the Society for General System Research, 4:171-184.

Gates, Jr., G. e. a. (1995). Parallel simple and fast messy gas for protein structure prediction. In Proceedings of the Intel Supercomputer Users' Group 1995 Annual North America Users Conference. Beaverton, Oregon: Intel Supercompurer Systems Division.

Goldberg, D. and Holland, J. (1988). Genetic algorithms and machine learning. Mach. Learn., 3(2-3):95-99.

Goldberg, D. E. (1989). Genetic Algorithms in Search, Optimization, and Machine Learning. Addison-Wesley Publishing Company, Inc., Reading, MA.

Gomes, J. and Saavedra, O. (1999). Optimal reactive power dispatch using ecolutionary computation: Extend aldorithms. In IEE Proc.-Gene. Tranmition. Distrib., Vol. 146.

Hajela, P. and Lin, C. Y. (1992). Genetic search strategies in multicriterion optimal design. Structural Optimization, 4:99-107.

Hilbert, M., Böhm, G., and Jaenicke, R. (1993). Structural relationships of homologous proteins as a fundamental principle in homology modeling. Proteins, 17:138-151.

Hohm, T. and Hoffman, D. (2005). A multi-objective evolutionary approach to peptide structure redesign and stabilization. In Proceedings of GECCO 2005, pages 423-429.

Holland, J. (1975). Adaptation in natural and artificial systems. University of Michigan Press.

Holland, J. (1992). Adaptation in natural and artificial systems. MIT Press. 
Horn, J., Nafpliotis, N., and Goldberg, D. (1994). A Niched Pareto Genetic Algorithm for Multiobjective Optimization. In Proceedings of the First IEEE Conference on Evolutionary Computation, IEEE World Congress on Computational Intelligence, volume 1, pages 82-87, Piscataway, New Jersey. IEEE Service Center.

Inbar, Y., Benyamini, H., Nussinov, R., and Wolfson, H. (2003). Protein structure prediction via combinatorial assembly of sub-structural units. Bioinformatics, 19:158-168i.

Inbar, Y., Wolfson, H., and Nussinov, R. (2005). Multiple docking for protein structure prediction. The International Journal of Robotics Research, pages 131-150.

Ishida, T., Nishimura, T., Nozaki, M., Inoue, T., Terada, T., Nakamura, S., and Shimizu, K. (2003). Development of an ab initio protein structure prediction system able. Genome Informatics, 14:228-237.

Jong, K. A. D. (1975). An analysis of the behavior of a class of genetic adaptive systems. PhD thesis.

Judson, R. (1992). Teaching polymers to fold. The Journal of Physical Chemistry, 96.

Judson, R. (1993). Reduced representation model of protein structure prediction: Statistical potential and genetic algorithms. Protein Science, 2:763-785.

Judson, R., Colvin, M., Meza, J., Huffer, A., and Gutierrez, D. (1992). Do intelligent configuration search techniques outperform random search for large molecules? International Journal of Quantum Chemistry, 44:277-290.

Kabsch, W. and Sander, C. (1983). Dictionary of protein secondary structure: pattern recognition of hydrogen bonded and geometrical features. Biopolymers, 22:2577-2637.

Karplus, M. and Shakhnovich, E. (1992). Protein Folding, chapter Protein Folding: Theorical Studies of Thermodynamics and Dynamics. W. H. Freeman and Company.

Khimasia, . and Coveney, . (1997). Protein structure prediction as a hard optimization problem: the genetic algorithm approach. In Molecular Simulation.

Kinnear, K. (1994). Advances in Genetic Programming. The MIT Press.

Kita, H., Yabumoto, Y., Mori, N., and Nishikawa, Y. (1996). Multi-Objective Optimization by Means of the Thermodynamical Genetic Algorithm. In Voigt, H.-M., Ebeling, W., Rechenberg, I., and Schwefel, H.-P., editors, Parallel Problem Solving from 
Nature-PPSN IV, Lecture Notes in Computer Science, pages 504-512, Berlin, Germany. Springer-Verlag.

Knowles, J. and Corne, D. (1999). The Pareto Archived Evolution Strategy: A New Baseline Algorithm for Multiobjective Optimisation. In 1999 Congress on Evolutionary Computation, pages 98-105, Washington, D.C. IEEE Service Center.

Kolinski, A. (2004). Reduced models of proteins and their applications. Polymer, $45(2): 511-524$.

Kolodner, J. (1993). Adaptation methods and strategies. In Case-Based Reasoning. Capitulo 11. Morgan Kaufmann.

Koza, J. (1992). Genetic Programming: On the Programming of Computers by Means of Natural Selection (Complex Adaptive Systems). MIT Press.

Krasnogor, N., Hart, W., Smith, J., and Pelta, D. (1999). Protein structure prediction with evolutionary algorithms. In Banzhaf, W., Daida, J., Eiben, A., Garzon, M., Honavar, V., Jakaiela, M., and Smith, R., editors, Genetic and Evolutionary Computation Conference.

Laumanns, M., Rudolph, G., and Schwefel, H.-P. (1998). A Spatial Predator-Prey Approach to Multi-Objective Optimization: A Preliminary Study. In Eiben, A. E., Schoenauer, M., and Schwefel, H.-P., editors, Parallel Problem Solving From Nature - PPSN $V$, pages 241-249, Amsterdam, Holland. Springer-Verlag.

Leake, D. (1996). CBR in context: The present and future. In Case-Based Reasoning: Experiences, Lessons and Future Directions. Capitulo 1. AAAI Press/MIT Press.

Legrand, S. and Kenneth, M. (1991). The application of the genetic algorithm to the minimization of potential energy functions. Journal of Global Optimization, 3:49-66.

Lehninger, A. (1976). Bioquímica. Edgard Blucher Ltda.

Lemer, C., Rooman, M., and Wodak, S. (1995). Protein structure prediction by threading methods: evaluation of current techniques. Proteins, 23:337-355.

Levitt, M. and Chothia, C. (1976). Structural patterns in globular proteins. Nature, 261:552-558.

Luenberger, D. (1984). Linear and Nonlinear Programming. Addison-Wesley Publishing Company. 
Mamdami, E. (1974). Application of fuzzy algorithms for the control of a simple dynamic plant. IEEE, pages 121-158.

McGarrath, D. and Judson, R. (1993). Analysis of the genetic algorithm method of molecular conformation determination. Journal of Computational Chemistry, 14:13851395.

Meidanis, J. and Setubal, J. (1997). Introduction to Computational Molecular Biology. Brooks and Cole Publishing Europe.

Mendel.G. (1865). Ensaio com plantas híbridas.

Merkle, L., Gaulke, R., Lamont, G., Gates Jr., G., and Pachter, R. (1996). Hybrid genetic algorithms for polypeptide energy minimization. In SAC'96: Proceedings of the 1996 ACM symposium on Applied Computing, pages 305-311. ACM Press.

Michalewicz, Z. (1996). Genetic algorithms + Data Structures = Evolution Programs. Springer-Verlag New York, Inc.

Michalewicz, Z. and Fogel, D. (2004). How to Solve It: Modern Heuristics. Springer-Verlag New York, Inc.

Michalewicz, Z. and Schoenauer, M. (1996). Evolutionary algorithms for constrained parameter optimization problems. Evolutionary Computation, 4:1-32.

Mohan, K., Sheik, S., Ramesh, J., Balamurugan, B., Jeyasimhan, M., Mayilarasi, C., and Sekar, K. (2005). Conformational angle database - cadb 2.0.

Morse, P. M. (1929). Diatomic molecules according to the wave mechanics. ii. vibrational levels. Phys. Rev., 34(1):57-64.

Nogueira, M. and Saavedra, O. (1999). Estratégias evolutivas aplicadas à resolução de otimização multimodal. In Simpósio Brasileiro de Automação Inteligente.

O’Toole, E. and Panagiotopoulos, A. (1992). Monte carlo simulation of folding transitions of simple model proteins using chain growth algorithm. J. Chem. Phys., 97.

Park, S.-J. (2005). A study of fragment-based protein structure prediction: Biased fragment replacement for searching low-energy conformation. Genome Informatics, 16:104113.

Peitsch, M. (2002). About the use of protein models. Bioinformatics, 18:934-938. 
Petsko, G. and Ringe, D. (2004). Proteins Structure and Function. New Science Press Ltd.

Ponder, J. (2001). Tinker software tools for molecular design. washington university, saint louis.

Ramachandran, G. and Sasiskharan, V. (1968). Conformation of polypeptides and proteins. Protein Chem., 23:283-437.

Rechenberg, I. (1973). Evolutionsstrategie: Optimierung technischer Systeme nach Prinzipien der biologischen Evolution. Frommann-Holzboog.

Rezende, S. (2003). Sistemas Inteligentes. Editora Manole.

Rudolph, G. (2001). Evolutionary Search under Partially Ordered Fitness Sets. In Proceedings of the International NAISO Congress on Information Science Innovations (ISI 2001), pages 818-822. ICSC Academic Press: Millet/Sliedrecht.

Schaffer, J. (1985). Multiple objective optimization with vector evaluated genetic algorithms. In Genetic Algorithms and their Applications: Proceedings of the First International Conference on Genetic Algorithms, pages 93-100. Lawrence Erlbaum.

Schug, A. and Wenzel, W. (2006). An Evolutionary Strategy for All-Atom Folding of the 60-Amino-Acid Bacterial Ribosomal Protein L20. Biophys. J., 90(12):4273-4280.

Schulz, G. and Schirmer, R. (1979). Principles of Protein Structure. Springer-Verlag.

Schulze-Kremer, S. (1993). Genetic algorithms for protein tertiary structure prediction. In ECML '93: Proceedings of the European Conference on Machine Learning, pages 262-279. Springer-Verlag.

Schwefel, H.-P. (1975). Evolutionsstrategie und numerische optimierung. Technical report, Technische Universität.

Service., E. B. P. (2006). van der waals forces.

Shi, S., Suganthan, P., and Deb, K. (2004). Multi-class protein fold recognition using multi-objective evolutionary algorithms. In KanGAL Report Number $200400 \%$.

Silva Junior, C. and Sasson, S. (2003). Biologia. Saraiva. 
Simons, K. T., Bonneau, R., Ruczinski, I., and Baker, D. (1999). Ab initio protein structure prediction of casp iii targets using rosetta. Proteins Suppl 3, pages 171-176.

Srinivas, N. and Deb, K. (1994). Multiobjective Optimization Using Nondominated Sorting in Genetic Algorithms. Evolutionary Computation, 2(3):221-248.

Sun, S. e. a. (1992). Biophysics Journal, 62.

Sywerda, G. (1989). Uniform crossover in genetic algorithms. In Proceedings of the third international conference on Genetic algorithms, pages 2-9. Morgan Kaufmann Publishers Inc.

Tuffery, P., Etchebest, C., Hazout, S., and Lavery, R. (1991). A new approach to the rapid determination of protein side chain conformations. Journal of Biomolecular Structure e Dynamics, 8:1267-1289.

Tuffery, P. e. a. (2003). Rotamer library.

Unger, R., Harel, D., Wherland, S., and Sussman, J. (1989). A 3-d building blocks approach to analyzing and predicting structure of proteins. Proteins: Struct. Funct. Genet., 5:355-373.

Unger, R. and Moult, J. (1993). Genetic algorithms for protein folding simulations. Journal of Molecular Biology, 231:75-81.

Veldhuizen, D. (1999). Multiobjective Evolutionary Algorithms: Classifications, Analyses, and New Innovations. PhD thesis, Department of Electrical and Computer Engineering. Graduate School of Engineering. Air Force Institute of Technology, Wright-Patterson AFB, Ohio.

Vullo, A. (2002). On the role of machine learning in protein structure determination. AIIA.

Wilson, I., Haft, D., Getzoff, E., Tainer, J., Lerner, R., and Brenner, S. (1985). Identical short peptide sequences in unrelated proteins can have different conformations: A testing ground for theories of immune recognition. Proc. Natl. Acad. Sci., 82:5255-5259.

Yao, X. and Liu, Y. (1993). Fast evolution strategies. In Proceedings 5th Annual Conference Evolutionary Programming, pages 451-460. MIT Press.

Zitzler, E., Deb, K., and Thiele, L. (2000). Comparison of Multiobjective Evolutionary Algorithms: Empirical Results. Evolutionary Computation, 8(2):173-195. 
Zitzler, E., Laumanns, M., and Thiele, L. (2001). SPEA2: Improving the Strength Pareto Evolutionary Algorithm. Technical Report 103, Computer Engineering and Networks Laboratory (TIK), Swiss Federal Institute of Technology (ETH) Zurich, Gloriastrasse 35, CH-8092 Zurich, Switzerland.

Zitzler, E. and Thiele, L. (1998). An Evolutionary Algorithm for Multiobjective Optimization: The Strength Pareto Approach. Technical Report 43, Computer Engineering and Communication Networks Lab (TIK), Swiss Federal Institute of Technology (ETH), Zurich, Switzerland. 


\section{Glossário}

Angstron $(\AA)$ : medida de comprimento molecular onde, $1 \AA=10^{-10} \mathrm{~m}$

Cadeia Polipeptídica: grupos de resíduos ligados por ligações peptídicas.

Cristal de Proteína: conjunto tridimensional de moléculas no qual cada uma possui a mesma orientação em um mesmo ambiente químico, mantendo o mesmo tipo de relação com as suas vizinhas.

Dalton: medida de peso molecular onde, 1 dalton $=1 \mathrm{~g} / \mathrm{mol}$.

Domínio: unidade compacta de estrutura de proteína capaz de dobrar-se em uma estrutura estável, como uma entidade independente na solução.

Hidrofílica: característica de uma molécula polar que forma pontes de hidrogênio suficientes com a água para se dissolver rapidamente.

Hidrofóbica: característica de uma molécula não-polar que não pode formar interações favoráveis com as moléculas de água, não se dissolvendo em água.

Interação de Van der Waals: uma fraca força atrativa entre dois átomos ou grupos de átomos, surgimento de flutuações na distribuição de eletróns ao redor do núcleo. Forças de Van der Waals são fortes entre átomos menos eletronegativos tais como os encontrados em grupos hidrofóbicos.

Ligação Peptídica: é uma ligação química formada quando um grupo carboxila $(-\mathrm{COOH})$ condensa com um grupo amino $\left(-\mathrm{NH}_{2}\right)$ com a expulsão de uma molécula de água $\left(\mathrm{H}_{2} \mathrm{O}\right)$. Somente é utilizado quando ambos os grupos pertencem a aminoácidos.

Motivo: sequência característica ou estrutura.

Motivo Estrutural: motivo que pode compreender um domínio completo ou proteína, mas geralmente consiste de um pequeno arranjo local de elementos de estrutura secundária. 
Motivo Sequencial: são sequências de aminoácidos reconhecíveis encontradas em diferentes proteínas, geralmente indicam a função bioquímica.

Ponte de Dissulfeto: ligação covalente formada entre dois grupos sulfidril de cisteínas.

Ponte de Hidrogênio: ligação correspondente a um átomo de hidrogênio covalentemente ligado a um átomo eletronegativo (como o oxigênio ou o nitrogênio).

Resíduos: nome referente aos aminoácidos quando presentes em um peptídio.

Ribossomo: organelas localizadas no interior das células, onde ocorre síntese de proteínas. 


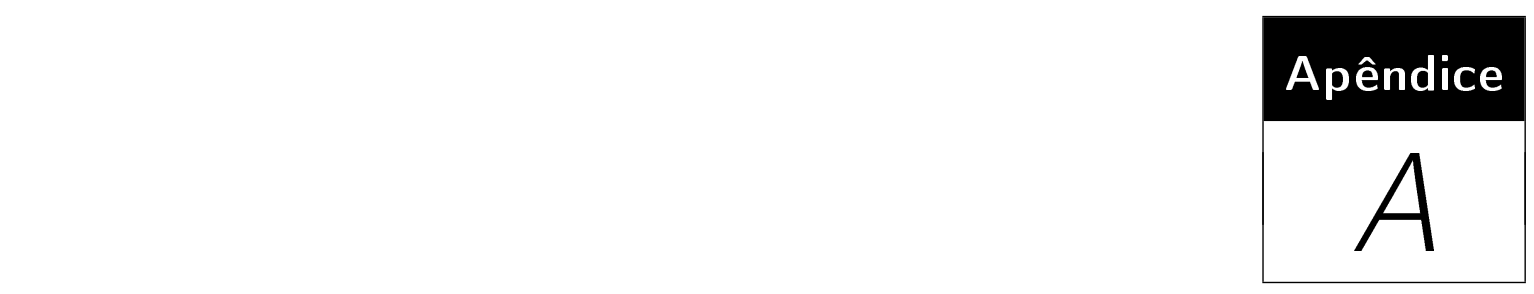

\section{Exemplo do arquivo de Parâmetros}

Neste apêndice é apresentado uma parte do arquivo de parâmetros charmm27.prm utilizado para o cálculo das energias potenciais das proteínas. As linhas iniciadas com os caracteres // não constam do arquivo origina. Essas linhas correspondem a comentários sobre as informações sobre o conteúdo da linha abaixo do comentário.

//Tipo de potencial de van der Waals vdwtype LENNARD-JONES

//Regra para o cálculo da distância entre os átomos radiusrule ARITHMETIC

//Tipo de raio radiustype R-MIN

//Tamanho de raio radiussize RADIUS

//Regra para cálculo do epsilon de van der Waals epsilonrule GEOMETRIC

//Escala de van der Waals para átomos separados por 3 ligações vdw-14-scale 1

//Escala de carga para átomos separados por 3 ligações chg-14-scale 1

//Constante dielétrica para cáculo da energia eletrostática dielectric 1

//Tipos dos átomos

//Palavra chave // Número do átomo // Classe do átomo // Código do átomo // Descrição // Número atômico // Peso //Número de ligações atom $11 \mathrm{HA}$ "Non polar Hydrogen"1 1.0081 
atom 22 HP "Aromatic Hydrogen"1 1.0081

atom $2010 \mathrm{C}$ "Peptide Carbonyl"6 12.0113

atom $2111 \mathrm{CA}$ "Aromatic Carbon"6 12.0113

atom 2212 CC "C-Term Carboxy late"6 12.0113

atom 2313 CT1 "Peptide Alpha Carbon"6 12.0114

atom 6324 NH1 "Peptide Nitrogen"7 14.0073

atom 6425 NH2 "Amide Nitrogen"7 14.0073

atom 6526 NH3 "Ammonium Nitrogen"7 14.0074

atom $7434 \mathrm{O}$ "Peptide Oxygen"8 15.9991

atom $7534 \mathrm{O}$ "ASN/GLN Carbonyl"8 15.9991

atom 7635 OH1 "Hydroxyl Oxygen"8 15.9992

atom $8037 \mathrm{~S}$ "Thiol Sulfur"16 32.0602

atom 8137 S "Sulfide Sulfur"16 32.0602

atom 8238 SM "Disulfide Sulfur"16 32.0602

//Parâmetros para os cálculos de van der Waals

//Palavra chave // Classe do átomo // Raio do átomo // Epsilon

vdw $11.3200-0.0220$

vdw $21.3582-0.0300$

vdw $102.0000-0.1100$

vdw $111.9924-0.0700$

vdw $122.0000-0.0700$

vdw $132.2750-0.0200$

vdw $241.8500-0.2000$

vdw $251.8500-0.2000$

vdw $261.8500-0.2000$

vdw $341.7000-0.1200$

vdw $351.7700-0.1521$

vdw $372.0000-0.4500$

vdw $381.9750-0.3800$

vdw14 $131.9000-0.0100$

vdw14 $241.5500-0.2000$

vdw14 $341.4000-0.1200$

//Parâmetros para os cálculos de comprimento de ligação

//Palavra chave // Classe do átomo 1 // Classe do átomo 2// Energia no comprimento ideal // Comprimento ideal

bond 110330.001 .1000

bond 111340.001 .0830

bond 112317.131 .1000

bond 113309.001 .1110

bond 324440.000 .9970

bond 325480.001 .0000

bond 1013250.001 .4900 
bond 1033463.001 .3650

bond 1034620.001 .2300

bond 2122350.001 .4400

bond 2232270.001 .3750

bond 3838173.002 .0290

//Parâmetros para os cálculos de ângulo de ligação

//Palavra chave // Classe do átomo 1 // Classe do átomo 2// Classe do átomo 3// Energia no ângulo ideal // Ângulo ideal

angle 3103450.00121 .70

angle 13102480.00116 .50

angle 13102720.00112 .50

angle 13103480.00121 .00

angle 27103480.00122 .50

angle 33103352.00120 .00

angle 2112132.00125 .00

angle 11113545.20120 .00

angle 211132120.00110 .00

angle 1122544.00111 .00

angle 13122550.00116 .50

angle 16122580.00112 .50

angle 25123475.00122 .50

angle 361236100.00124 .00

angle 292030130.00112 .50

angle 222232110.00107 .40

angle 15383872.50103 .30

//Parâmetros para os cálculos das interações Urey-Bradley

//Palavra chave // Classe do átomo 1 // Classe do átomo 2 // Classe do átomo 3// Energia na distância ideal // Distância ideal

ureybrad 33103390.002 .3642

ureybrad 1111125.002 .1525

ureybrad 1112125.002 .1730

ureybrad 11111135.002 .4162

ureybrad 21113225.002 .2400

ureybrad 25123450.002 .3700

ureybrad 36123670.002 .2250

ureybrad 1313148.002 .5610

ureybrad 1513158.002 .5610

ureybrad 11415.401 .8020

ureybrad 3312015.002 .0900

//Parâmetros para os cálculos da energia imprópria

//Palavra chave // Classe do átomo 1 // Classe do átomo 2// Classe do átomo 3 // 
Classe do átomo 4 // Energia no ângulo de torsão ideal // Ângulo de torsão ideal improper 10132434120.000 .00

improper 1013253490.000 .00

improper 10152734120.000 .00

improper 10162434120.000 .00

improper 241014320.000 .00

//Parâmetros para os cálculos da energia de torsão

//Palavra chave // Classe do átomo 1 // Classe do átomo 2 // Classe do átomo 3 //

Classe do átomo 4// Constante da fase // Ângulo da fase // Fase // Os três últimos campos repetem-se até 6 fases

torsion 2410134

torsion 2710134

torsion 271013240.4000 .01

torsion 24101640.400180 .010 .6000 .02

torsion $241016270.3000 .01-0.3000 .04$

torsion $34101627-0.3000 .04$

torsion 14102432.500180 .02

torsion 141024131.6000 .012 .500180 .02

torsion 131027162.750180 .020 .3000 .04

torsion 251213260.4000 .010 .050180 .06

torsion 36121340.050180 .06

torsion 361213263.200180 .020 .050180 .06

torsion 13133531.3300 .010 .1800 .020 .3200 .03

//Parâmetros para os cálculos das interações eletrostáticas

//Palavra chave // Número do átomo// Carga do átomo

charge 10.090

charge 20.115

charge 200.510

charge $21-0.115$

charge $22 \quad 0.340$

charge 230.070

charge $63-0.470$

charge $64-0.620$

charge $65-0.300$

charge $74-0.510$

charge $75-0.550$

charge $76-0.660$

charge $80-0.230$

charge $81-0.090$

charge $82-0.080$ 